Florida International University FIU Digital Commons

\title{
The Effects of Fertilization and Simulated Grazing on the Community Structure of a Seagrass Bed in South Florida
}

Sitti Zayda B. Halun

Florida International University, shalu002@fiu.edu

DOI: $10.25148 /$ etd.FI1 1042501

Follow this and additional works at: https://digitalcommons.fiu.edu/etd

\section{Recommended Citation}

Halun, Sitti Zayda B., "The Effects of Fertilization and Simulated Grazing on the Community Structure of a Seagrass Bed in South Florida" (2011). FIU Electronic Theses and Dissertations. 415.

https://digitalcommons.fiu.edu/etd/415 


\section{FLORIDA INTERNATIONAL UNIVERSITY}

Miami, Florida

THE EFFECTS OF FERTILIZATION AND SIMULATED GRAZING ON THE COMMUNITY STRUCTURE OF A SEAGRASS BED IN SOUTH FLORIDA

A dissertation submitted in partial fulfillment of the requirements for the degree of DOCTOR OF PHILOSOPHY

in

\section{BIOLOGY}

by

Sitti Zayda Halun 
To: $\quad$ Dean Kenneth Furton

College of Arts and Sciences

This dissertation, written by Sitti Zayda Halun, and entitled The Effects of Fertilization and Simulated Grazing on the Community Structure of a Seagrass Bed in South Florida, having been approved in respect to style and intellectual content, is referred to you for judgment.

I have read this dissertation and recommend that it be approved.

Jennifer H. Richards

$\begin{array}{r}\hline \text { Joel C. Trexler } \\ \hline \text { Piero R. Gardinali } \\ \hline \text { Steven F. Oberbauer } \\ \hline \text { James W. Fourqurean, Major Professor }\end{array}$

Date of Defense: January 18, 2011

The dissertation of Sitti Zayda Halun is approved.

\begin{tabular}{r}
$\begin{array}{r}\text { Dean Kenneth Furton } \\
\text { College of Arts and Sciences }\end{array}$ \\
\hline Interim Dean Kevin O'Shea \\
University Graduate School
\end{tabular}

Florida International University, 2011 


\section{DEDICATION}

To appah and mamang 


\section{ACKNOWLEDGMENTS}

This research project would not have been possible without the help of many people. I wish to express my gratitude to everyone who was a part of this journey.

My major professor, Jim Fourqurean, for the interesting discussions, his guidance, patience and support during my stay in FIU.

My committee members past and present: Jennifer Richards, Joel Trexler, Steve

Oberbauer, Piero Gardinale, Michael McClain, Tom Philippi, and Michael Maunder, for their valuable and thoughtful comments

Jorge Terrados, special thanks for the suggestions that helped improve this project.

Miguel D. Fortes, for his friendship, advice and support through the years.

Seagrass rangers and friends: Rebecca Bernard, Justin Campbell, Jeana Drake, Pamela Parker, Dave Ward, Ginny Cornett, Chris Freeman, Elizabeth Lacey, Chrisna Luus, Alex Carreño, Ligia Collado-Vides, Nicole Chavarry, Zita Zalai, for their help in the lab and field.

Laura May-Collado, Jennifer Lewis, Josette La Hee, and Brian Sidoti for their friendship that kept me going.

My family, for the unconditional love and support. 


\begin{abstract}
OF THE DISSERTATION
THE EFFECTS OF FERTILIZATION AND SIMULATED GRAZING ON THE COMMUNITY STRUCTURE OF A SEAGRASS BED IN SOUTH FLORIDA

by
\end{abstract}

Sitti Zayda Halun

Florida International University, 2011

Miami, Florida

Professor James W. Fourqurean, Major Professor

The importance of resource supply and herbivory in driving competitive interactions among species has been an important but contentious issue within ecology. These variables exhibit different effects on species competition when manipulated in isolation but interact when manipulated together. I tested the direct and interactive effects of nutrient addition and simulated grazing (clipping) on the competitive performance of primary producers and community structure of a seagrass bed in South Florida. One square meter experimental plots were established in a mixed seagrass meadow from August 2007 to July 2009. The experiment was a $3 \times 3$ factorial experiment: 3 fertility treatments: control, medium (2.4 $\mathrm{mg} \mathrm{N} \mathrm{d}^{-1}$ and $80 \mu \mathrm{g} \mathrm{P}$ day $\left.{ }^{-1}\right)$ and high $\left(4.8 \mathrm{mg} \mathrm{N} \mathrm{d}^{-1}\right.$ and $160 \mu \mathrm{g} \mathrm{P}$ day $\left.^{-1}\right)$ x 3 clipping intensities $(0,25 \%$ and $50 \%$ biomass removal $(\mathrm{G}))$ × 5 replicates for each treatment $=45$ plots). Nutrient additions and simulated grazing were done every two months. Fertilization and simulated grazing decreased sexual reproduction in S. filiforme. Fertilization increased competitive dominance within the primary producers while simulated grazing counteracted this effect by removal of the dominant species. Fertilization ameliorated the negative impacts of simulated grazing 
while simulated grazing prevented competitive exclusion in the fertilized plots. Nutrient addition and simulated grazing both exerted strong control on plant performance and community structure. Neither bottom up nor top down influences was eliminated in treatments where both factors where present. The effects of fertilization on plant performance were marked under all clipping intensities indicating that the system is regulated by nutrient availability both in the presence or absence of grazers. Clipping effects were strong under both fertilized and unfertilized conditions indicating that the seagrass bed can be simultaneously under top-down control by grazers 
CHAPTER 1. INTRODUCTION: PREDICTING THE DIRECT AND INTERACTIVE EFFECTS OF FERTILIZATION AND SIMULATED GRAZING ON SEAGRASS COMMUNITY STRUCTURE..

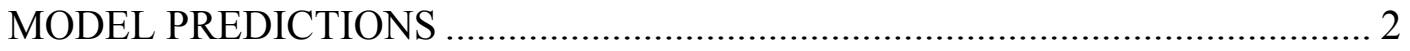

CHAPTER 2: THE EFFECTS OF FERTILZATION AND SIMULATED GRAZING ON THE MORPHOLOGY AND PRODUCTIVITY OF A SUBTROPICAL SEAGRASS ...................... 11

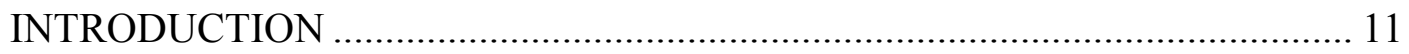

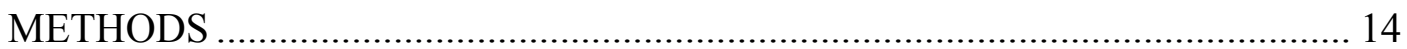

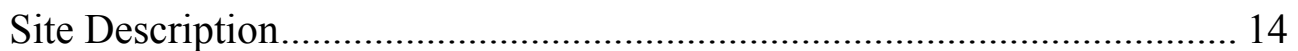

Experimental design....................................................................... 14

Experimental sampling ................................................................ 16

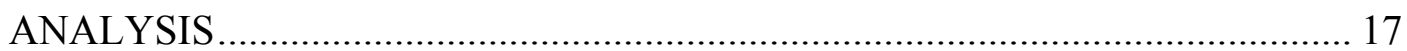

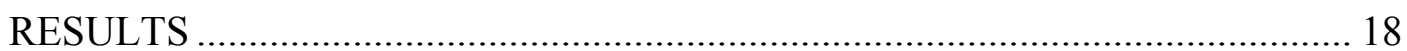

Leaf nutrient content ...................................................................... 18

Morphology of seagrasses................................................................. 19

Growth rate of seagrasses ............................................................ 19

Absolute abundance of primary producers .......................................... 20

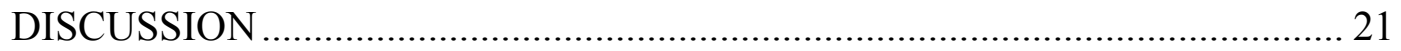

CHAPTER 3: TEMPORAL CHANGE IN THE COMMUNITY STRUCTURE OF A SUBTROPICAL SEAGRASS BED IN RESPONSE TO THE DIRECT AND INTERACTIVE

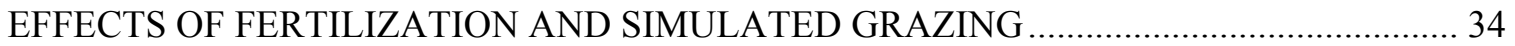

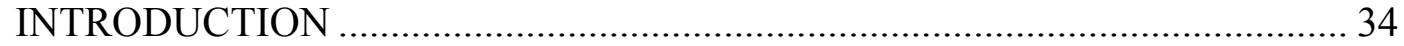

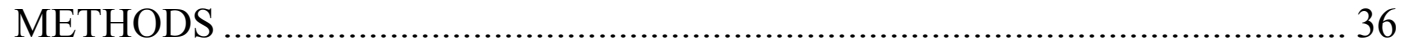

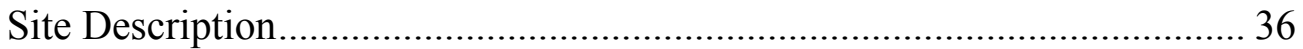

Experimental design and treatments ................................................. 36

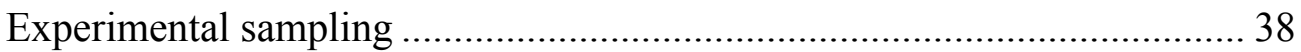

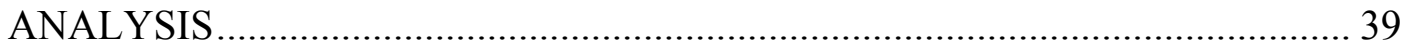

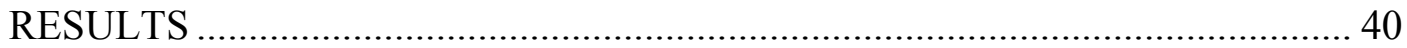

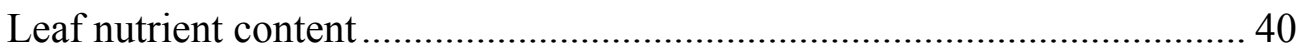

Absolute abundance of primary producers ............................................. 41

Number of Species and Species Evenness ............................................... 43

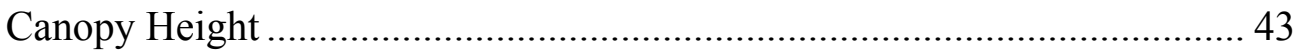


CHAPTER 4: THE EFFECTS OF FERTILIZATION AND SIMULATED GRAZING ON THE FLOWERING OF THE SEAGRASS SYRINGODIUM FILIFORME (KÜTZING) .................... 75

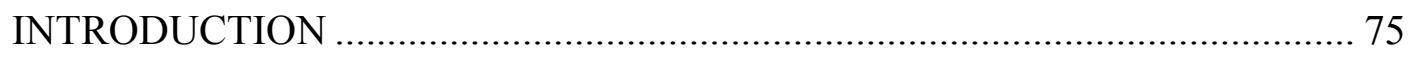

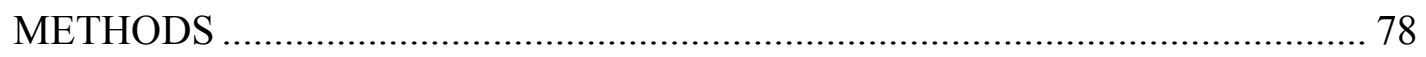

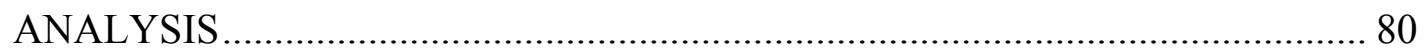

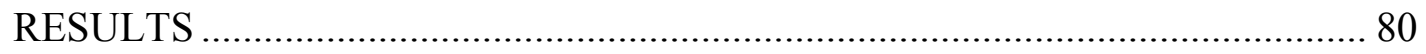

Absolute abundance of seagrasses ..................................................... 80

Syringdium filiforme leaf length and leaf mass...................................... 81

CNP content of $S$. filiforme leaf and flowers ........................................ 81

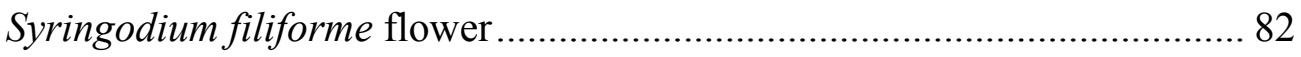

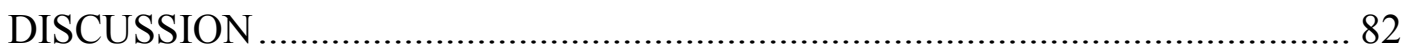

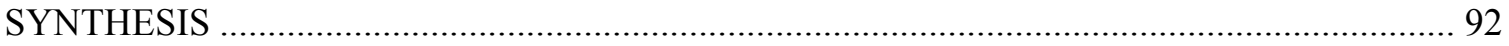

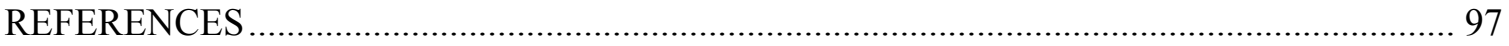

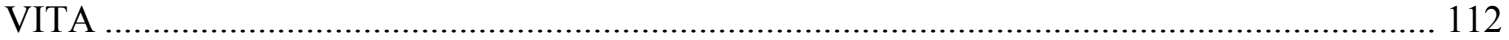




\section{LIST OF TABLES}

TABLE

PAGE

Table 2.1: ANOVA results of effects of nutrients and grazing on response variables measured after 24 months of fertilization and grazing.

Table 3.1 Repeated measures analysis of variance of the effect of nutrient and simulated grazing on response variables measured for two years..............51

Table 3.2 ANOVA results of effects of nutrients and grazing on the absolute abundance of primary producers measured during the 24-month fertilization and grazing experiment

Table 3.3 ANOVA results on the effects of grazing on the absolute cover of S. filiforme at different fertilization regimes

Table 3.4 ANOVA results of effects of nutrients and grazing on canopy height measured during the 24 month fertilization and grazing experiment...

Table 4.1 ANOVA results of effects of nutrients and grazing on response variables measured in April 2009 


\section{LIST OF FIGURES}

FIGURE

PAGE

Figure 1.1. A conceptual model relating nutrient availability (trophic state) to relative abundance of primary producers in near shore marine waters of South Florida ....

Figure 1.2. A conceptual model relating nutrient availability (trophic state) and grazing intensity to relative abundance of primary producers in near shore marine waters of South Florida.

Figure 2.1: The direct and interactive effects of fertilization and simulated grazing on (A) T. testudinum leaf N, (B) T. testudinum leaf P, (C) S. filiforme leaf N and (D) $S$. filiforme leaf $\mathrm{P}$ content as a percent of dry weight (means \pm standard error). Mean values in a group of bars followed by different letters are significantly different $(\mathrm{p}<0.05$, Tukey's HSD test) .....

Figure 2. 2. The direct and interactive effects of fertilization and simulated grazing on (A) T. testudinum leaf C:N ratio, (B) T. testudinum leaf C:P ratio, (C) S. filiforme leaf C:N ratio and (D) S. filiforme leaf C:P ratio (means \pm standard error). Mean values in a group of bars followed by different letters are significantly different ( $\mathrm{p}<0.05$, Tukey's HSD test)....

Figure 2.3. The direct and interactive effects of fertilization and simulated grazing on (A) T. testudinum leaf area, (B) T. testudinum leaf mass, (C) S. filiforme leaf length and (D) S. filiforme leaf mass (means \pm standard error). Mean values in a group of bars followed by different letters are significantly different $(\mathrm{p}<0.05$, Tukey's HSD test)

Figure 2.4. The direct and interactive effects of fertilization and simulated grazing on (A) T. testudinum leaf AGR, (B) T. testudinum leaf RGR, (C) T. testudinum leaf PI, (means \pm standard error). Mean values in a group of bars followed by different letters are significantly different $(\mathrm{p}<0.05$, Tukey's HSD test. .

Figure 2.5. The direct and interactive effects of fertilization and simulated grazing on (A) $S$. filiforme leaf AGR and (B) S. filiforme leaf PI (means \pm standard error). Mean values in a group of bars followed by different letters are significantly different $(\mathrm{p}<0.05$, Tukey's HSD test)

Figure 2.6. The direct and interactive effects of fertilization and simulated grazing on the absolute abundance of (A) T. testudinum, (B) S. filiforme, (C) H. wrightii, (D) Halimeda, and (E) Penicillus (means \pm standard error). Mean values in a group of bars followed by different letters are significantly different $(\mathrm{p}<0.05$, Tukey's HSD test) 
Figure 3.1. The effects of fertilization on (A) T. testudinum leaf N, (B) T. testudinum leaf P, (C) S. filiforme leaf N and (D) S. filiforme leaf P content as a percent of dry weight (means \pm standard error). Asterisks indicate significant difference among treatments. $(\mathrm{p}<0.05$, Tukey's HSD test)

Figure 3.2. The effects of simulated grazing on (A) T. testudinum leaf N, (B) T. testudinum leaf P, (C) S. filiforme leaf N and (D) S. filiforme leaf P content as a percent of dry weight (means \pm standard error). Asterisks indicate significant difference among treatments. $(p<0.05$, Tukey's HSD test)

Figure 3.3. The interactive effects of fertilization and simulated grazing on T. testudinum leaf $\mathrm{N}$, and $\mathrm{S}$. filiforme leaf $\mathrm{N}$ content as a percent of dry weight (means \pm standard error). $(\mathrm{p}<0.05$, Tukey’s HSD test)

Figure 3.4. The interactive effects of fertilization and simulated grazing on T. testudinum leaf $\mathrm{P}$, and $\mathrm{S}$. filiforme leaf $\mathrm{P}$ content as a percent of dry weight (means \pm standard error). ( $p<0.05$, Tukey's HSD test).

Figure 3.5. The effects of fertilization on (A) T. testudinum leaf C:N ratio, (B) T. testudinum leaf C:P ratio, (C) S. filiforme leaf C:N ratio and (D) S. filiforme leaf $\mathrm{C}: \mathrm{P}$ ratio (means \pm standard error). Asterisks indicate significant difference

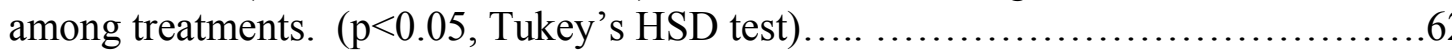

Figure 3.6. The effects of simulated grazing on (A) T. testudinum leaf C:N ratio, (B) T. testudinum leaf C:P ratio, (C) S. filiforme leaf C:N ratio and (D) S. filiforme leaf $\mathrm{C}: \mathrm{P}$ ratio (means \pm standard error). Asterisks indicate significant difference among treatments. $(\mathrm{p}<0.05$, Tukey's HSD test $)$.

Figure 3.7. The interactive effects of fertilization and simulated grazing on T. testudinum leaf C:N ratio, and $S$. filiforme leaf C:N ratio (means \pm standard error). ( $\mathrm{p}<0.05$, Tukey's HSD test)

Figure 3.8. The interactive effects of fertilization and simulated grazing on T. testudinum leaf leaf C:P ratio, and $S$. filiforme leaf C:P ratio (means \pm standard error). ( $\mathrm{p}<0.05$, Tukey's HSD test) 65

Figure 3.9. The effects of fertilization on the absolute abundance of (A) T. testudinum, (B) S. filiforme, (C) H. wrightii, (D) Halimeda, and (E) Penicillus (means \pm standard error). Asterisks indicate significant difference among treatments. ( $\mathrm{p}<0.05$, Tukey's HSD test)

Figure 3.10. The effects of simulated grazing on the absolute abundance of (A) T. testudinum, (B) S. filiforme, (C) H. wrightii, (D) Halimeda, and (E) Penicillus (means \pm standard error) at different time periods. $(\mathrm{p}<0.05$, Tukey's HSD test) 
Figure 3.11. The interactive effects of fertilization and simulated grazing on the absolute abundance of $T$. testudinum, $S$. filiforme, and $H$. wrightii (means \pm standard error) at different time periods. ( $\mathrm{p}<0.05$, Tukey’s HSD test)

Figure 3.12. The interactive effects of fertilization and simulated grazing on the absolute abundance of Halimeda, and Penicillus at different time periods (means \pm standard error). ( $\mathrm{p}<0.05$, Tukey's HSD test)....

Figure 3.13. The effects of fertilization on (A) number of species and (B) Species evenness (E) (means \pm standard error) at different time periods. Asterisks indicate significant difference among treatments.

$(\mathrm{p}<0.05$, Tukey's HSD test)....

Figure 3.14. The effects of simulated grazing on (A) number of species and (B) Species evenness (E) (means \pm standard error) at different time periods. Asterisks indicate significant difference among treatments.

$(\mathrm{p}<0.05$, Tukey's HSD test $)$.

Figure 3.15. The interactive effects of fertilization and simulated grazing on number of species and Species evenness (E) (means \pm standard error) at different time periods. ( $\mathrm{p}<0.05$, Tukey's HSD test).

Figure 3.16. The effects of fertilization and simulated grazing on seagrass canopy height (means \pm standard error). Asterisks indicate significant difference among treatments. $(\mathrm{p}<0.05$, Tukey's HSD test $)$.

Figure 3.17. The interactive effects of fertilization and simulated grazing on seagrass canopy height (means \pm standard error). ( $p<0.05$, Tukey's HSD test)........74

Figure 4.1. The direct and interactive effects of fertilization and simulated grazing on the absolute abundance of (A), S. filiforme, (B)T. testudinum, and (C) H. wrightii, (means \pm standard error). Mean values in a group of bars followed by different letters are significantly different $(\mathrm{p}<0.05$, Tukey's HSD test $)$

Figure 4.2. The direct and interactive effects of fertilization and simulated grazing on $S$. filiforme (A) leaf length, (B) leaf mass (means \pm standard error). Mean values in a group of bars followed by different letters are significantly different $(\mathrm{p}<0.05$, Tukey's HSD test)

Figure 4.3. The direct and interactive effects of fertilization and simulated grazing on S. filiforme (A) leaf N content, (B) leaf P content, (C) flower N content and (D) flower $\mathrm{P}$ content (means \pm standard error). Mean values in a group of bars followed by different letters are significantly different $(\mathrm{p}<0.05$, Tukey's HSD test) 
Figure 4.4. The direct and interactive effects of fertilization and simulated grazing on S. filiforme (A) \% flowering, (B) number of flowers per shoot, (C) number of flowering shoots per square meter (means \pm standard error). Mean values in a group of bars followed by different letters are significantly different ( $p<0.05$, Tukey's HSD test). 
CHAPTER 1. INTRODUCTION: PREDICTING THE DIRECT AND INTERACTIVE EFFECTS OF FERTILIZATION AND SIMULATED GRAZING ON SEAGRASS COMMUNITY STRUCTURE

Pervasive anthropogenic changes to coastal areas and consumer community structure pose a challenge to the ability of ecologists to predict responses of primary producers, plant community structure and ecosystem function to increasing nutrient supply and decrease in herbivory. Nitrogen and phosphorus are known to limit primary production in coastal ecosystems (Elser et al. 2007). However, the input rates of nitrogen and phosphorus to coastal ecosystems have increased due to changes in land use pattern, agricultural practices and human activities along the coastal zone causing massive eutrophication (Bonsdorff et al. 1997, Boesch 2002). Similarly, human-caused changes in the intensity of top-down control due to overfishing can change the standing biomass and composition of primary producers in coastal ecosystems (Jackson 2001, Jackson et al. 2001).

Earlier studies pursued the effects of fertilization and herbivory independently but contemporary research suggests that these two variables interact (Worm et al. 2002, Hillebrand 2003, Burkepile and Hay 2006). Earlier studies have provided support for the positive effect of nutrient addition (Tilman 1990, Fridley 2002) and herbivore removal (McNaughton 1985, Gruner 2004) on plant communities. However both models and case studies offer conflicting predictions and evidence as to whether bottom-up and top-down factors should independently or interactively control plant community structure biomass (Hawkes and Sullivan 2001, Worm et al. 2002, Hillebrand 2003, Hartley and Mitchell 2005, Burkepile and Hay 2006, Olsen and Valiela 2010). With the common recognition 
that both resources and consumer impacts play important roles in controlling primary productivity and community structure, research now focuses on quantifying the relative and interactive effects of these forces and in predicting how these forces determine producer standing biomass, productivity, and community composition.

Here I present a conceptual model predicting species density of a plant community at different nutrient and grazing regimes. I used natural history information to explain the direct and interactive effects of fertilization and grazing on plant community structure of a subtropical seagrass bed. A main implication of the results of this study is that a conceptual model integrated with a basic understanding of the mechanisms of interaction and supported by natural history information will increase our capabilities to understand and predict the dynamics of ecosystems. Increasing the predictive capabilities of ecological models is important for providing solutions to environmental problems.

The species composition of a community will depend on whether fertility or herbivory is the dominant driver of ecosystem structure. Since ecosystem properties are strongly influenced by the characteristics of the dominant plants (Grime 2001), it is particularly important to examine the direct and interactive effects of nutrient supply and herbivory in ecosystems that are usually dominated by one or a few species, such as most aquatic ecosystems (Engelhardt and Ritchie 2001, Fourqurean et al. 2001).

\section{MODEL PREDICTIONS}

Grime's (1979) "hump-backed" model of species density predicts that species diversity is expected to be highest at intermediate levels of fertility. In environments with 
very low concentrations of nutrients, species richness is low because only species that have low nutrient requirements survive (Tilman 1982). Conversely, in environments with high concentrations of nutrients, a further increase in the limiting nutrient results in a decrease in species richness. High concentration of resources has been suggested to favor fast growing species that tend to out-compete a slow-growing species and dominate the ecosystem (Grime 1973). The results of most experiments in which production has been increased by enrichment of soil resources have shown a corresponding decline in species diversity (Kirchner 1977, Goldberg and Miller 1990, Gough et al. 2000, Fridley 2002). The mechanism generally presumed to cause the decrease in species richness is an increased intensity of competition at higher plant biomass (Grime 1979, Huston 1979, Tilman 1988, Huston 1994).

Connell’s (1978) “intermediate disturbance hypothesis" predicts that species diversity peaks at intermediate levels of disturbance. Grazing increases species richness by preventing competitive exclusion through biomass removal of the dominant species (Lubchenco 1978, Proulx and Mazumder 1998). Wootton (1998), however, suggested two scenarios at which species diversity might not peak at intermediate levels of disturbance: 1) if species do not respond differentially to disturbance, then disturbance will not increase the probability of species coexistence (see also Chesson and Huntly 1997, Chesson 2000) and 2) if species coexistence is due to mechanisms other than the action of disturbance, then disturbance will either have no influence on species coexistence or will decrease the probability of species coexistence and lead to a reduction 
in diversity. The second scenario may occur due to the interactions between nutrient availability and disturbance.

Studies have shown that the effects of fertility and herbivory on species diversity may be interdependent (Proulx and Mazumder 1998). The net effects of grazers on community structure depend on the fertility of the habitat, which will determine the rates of competitive exclusion and the recovery after grazing (Lubchenco 1978, Huston 1979, Kondoh 2001). On the one hand, fertilization tends to increase the dominance of a few species (Lubchenco 1978, Proulx and Mazumder 1998) and thus to decrease evenness, whereas grazers counteract these effects by removing dominant life forms (Worm et al. 1999, Hillebrand 2003). On the other hand, the ability of plants to withstand disturbance, such as grazing and to recover afterwards correlates to nutrient input (Proulx and Mazumder 1998). The nutrient supply required to maintain high plant diversity increases with increasing mortality rates (Huston 1979, Hillebrand et al. 2000), and the effects of nutrients on diversity change with grazer presence or absence. Fertilization in the absence of herbivory increases biomass and decreases species density (Gough and Grace 1998). I present a conceptual model that predicts how species density is influenced by the interactive effects of nutrient supply and grazing intensity. I hypothesize that the interaction between nutrient availability and grazing will allow more species to coexist with increasing nutrient supply in the presence of herbivores. So I expect the peak in species diversity predicted by Grime's (1979) "hump-backed" model of species density to extend further into higher nutrient concentration in the presence of herbivores that will 
prevent competitive exclusion. The nutrient supply should be enough to support plant growth to allow the plant community to recover from grazing.

In this model, a gradient of plant growth rate is proposed, from fast-growing to slow growing plants. Fast growing species are associated with fertile environments, while slow growing species are associated with infertile environments (Grime 2001). Since ecosystem function is strongly affected by the functional characteristics of the dominant plant species, the rapid biomass production (high growth rate) can increase ecosystem productivity (Berendse et al. 1998). The low carbon to nutrient ratio of fastgrowing species increases their palatability to herbivores, therefore creating a possible loss of primary productivity (Cebrian and Duarte 1994, Grime 2001).

In infertile environments, slow-growing species dominate and their capacity to dominate is related more to the ability to protect nutrient capital than to capture nutrients at low external concentration (Berendse et al. 1998, Grime 2001). The foliage of plants associated with nutrient poor soils is usually characterized by low concentrations of mineral nutrient elements (Chapin 1980). The most likely explanation for this is the large investment in cell wall material and in other carbon-based structural components which appear to be involved in the defense of potentially long-lived leaves against herbivores (Chabot and Hicks 1982, Burt-Smith et al. 2003). Herbivores have been shown to prefer plants that have a high nutrient concentration (Burt-Smith et al. 2003, Goecker et al. 2005). The slow growth rate (biomass production) can lead to a lower ecosystem productivity compared to an ecosystem dominated by fast-growing plants, but the longer life span can indirectly increase ecosystem productivity in aquatic systems by allowing 
more epiphytes to grow on the plants (Reyes and Sanson 2001, Lavery and Vanderklift 2002).

In a seagrass bed, I hypothesize that the following scenarios could occur:

(1) An overall increase in the abundance of vegetation in fertilized plots while grazing will lead to an overall decrease in plant abundance. The total plant biomass will increase in response to the increased nutrient supply. Grazing will cause a loss of biomass and nutrients that will result in a decrease in total plant abundance.

(2) Community composition will change as a result of species-specific responses to increased nutrient supply. Species evenness will decline because of increasing dominance of some species. An increase in nutrient loading in the absence of herbivory will decrease the abundance of some species and allow species capable of exploiting the increased nutrient availability to dominate. Specifically I predict that tall plants (Syringodium filiforme and Thalassia testudinum) will increase whereas the smaller plant (Halodule wrightii) will decrease in the short term. In the long term, H. wrightii is expected to increase as predicted by Fourqurean's (2003) species dominance-eutrophication gradient conceptual model (Figure 1.2). This model predicts that the dominant species of primary producers in near-shore marine water of South Florida changes with changing nutrient concentration. The shift in the dominant species with increasing nutrient supply will be from $T$. testudinum, S. filiforme, $H$. wrightii, $R$. maritima, macroalgae to microalgae. Changes in seagrass community composition in response to increasing nutrient 
supply have been shown to occur on the scale of years and decades. In Florida Bay, a monospecific T. testudinum bed was replaced by $H$. wrightii following 8 years of fertilization (Fourqurean et al. 1995). Ferdie and Fourqurean (2004) reported an increase in S. filiforme and macroalgal abundance in response to fertilization, which could compete with $T$. testudinum for light and nutrients.

(3) an increase in grazing pressure without an increase in nutrient loading will lead to a loss of species, only species that are resistant to or tolerant of grazing will persist and;

(4) the interactive effects of nutrient availability and grazing will allow species to coexist at higher nutrient supply. The trajectory predicted by Fourqurean's (2003) model could be delayed if there are enough grazers to prevent the dominance of a few species (Figure 1.3). The maximum relative abundance of the different species would be reduced in the presence of herbivores.

It is important to determine the length of time required to cause shifts in vegetation abundance and composition to be able to predict changes in community structure in response to changes in nutrient supply and grazing pressure, so long term studies are required.

When ecosystems are subjected to multiple stressors simultaneously, their effects on community structure could be difficult to predict. In the face of multiple stressors, diverse ecosystems may be more stable if species respond differently to stressors or if 
functionally similar species can compensate for stressor effects on focal species (Loreau and Behera 1999). Mooney (1995) suggested that the gain or loss of a species will have the greatest impact on ecosystem processes and functions when there are few species in the community, especially when the species gained or lost is a dominant species. This is particularly important in ecosystems, such as kelp forests, cattail marshes, and seagrass beds that are dominated by and dependent on one or a few key plant species (Engelhardt and Ritchie 2001, Fourqurean et al. 2001). Thus understanding the effects of increasing nutrient supply and herbivore loss on ecosystem structure and function is critical in achieving both conservation and economic goals. The succeeding chapters will elucidate how species-specific responses to the direct and interactive effects of fertilization and grazing could change community composition of a seagrass bed. 


\section{Low grazing}
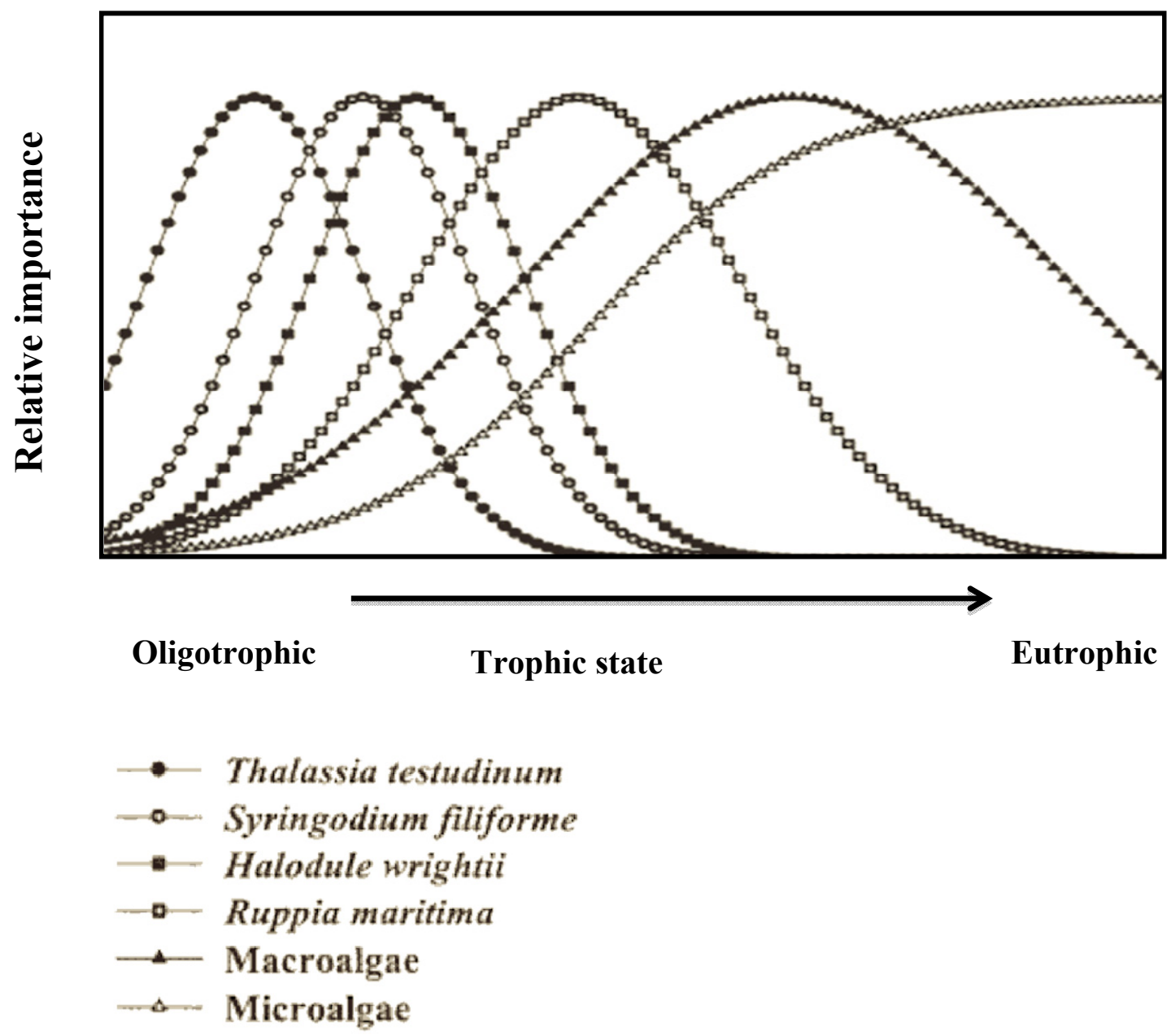

Figure 1.1 A conceptual model relating nutrient availability (trophic state) to relative abundance of primary producers in near-shore marine waters of South Florida (Fourqurean et al. 2003) 


\section{High Grazing}

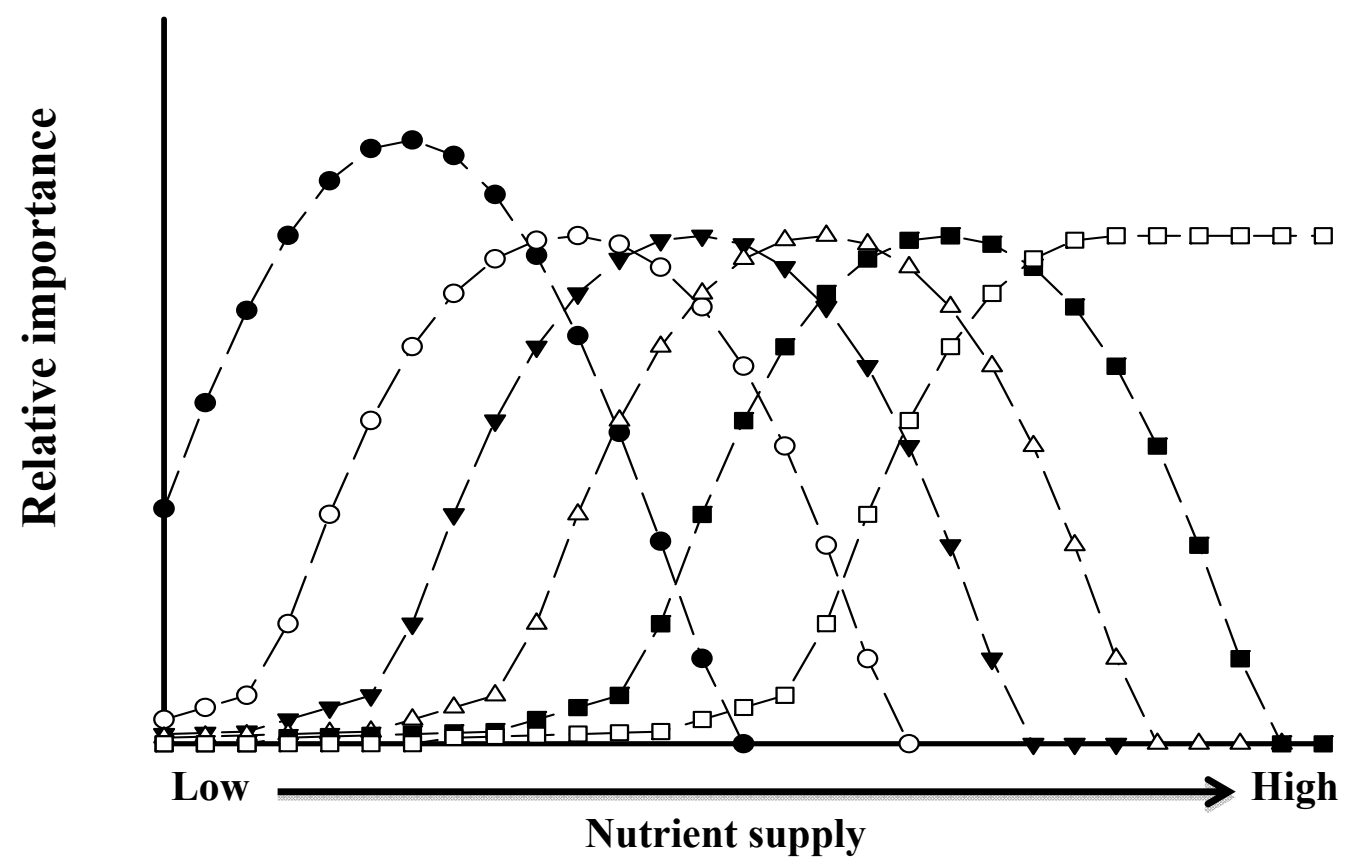

- T. testudinum

- S. filiforme

$\nabla \quad H$. wrightii

$\triangle \quad R$. maritima

- Macroalgae

․ Microalgae

Figure 1.2. A conceptual model relating nutrient availability to relative abundance of primary producers in near-shore marine waters of South Florida under high grazing pressure 
CHAPTER 2: THE EFFECTS OF FERTILZATION AND SIMULATED GRAZING ON THE MORPHOLOGY AND PRODUCTIVITY OF A SUBTROPICAL SEAGRASS

\section{INTRODUCTION}

The importance of resource supply (so-called "bottom-up" forces) and herbivory ("top-down" forces) in driving interactions among species has been an important but contentious issue within ecology (Gruner et al. 2008). Once a dichotomous debate over which single process best explained the observed patterns of primary production, current research suggests the interdependence of resources and consumer impacts on ecosystems (Hawkes and Sullivana 2001, Burkepile and Hay 2006). These variables exhibit different effects on species competition when manipulated in isolation but interact when manipulated together. Earlier studies provide widespread support for positive effects of experimental fertilization (Wilson and Tilman 1991, Fourqurean et al. 1995, Fridley 2002, Ferdie and Fourqurean 2004) and herbivore removal or exclusion on producer community across ecosystems (Ritchie and Tilman 1995, Foster and Gross 1998, Chase et al. 2000). On the one hand, fertilization tends to increase the dominance of a few species (Lubchenco 1978, Proulx and Mazumder 1998) whereas grazers counteracted these effects by removing dominant life forms (Gough and Grace 1998, Worm et al. 2002, Hillebrand 2003). The net effects of grazers on community structure depend on the fertility of the habitat, which will determine the rates of competitive exclusion and the recovery after grazing (Lubchenco 1978, Huston 1979, Proulx and Mazumder 1998, Kondoh2001). With the general recognition that both resources and consumers have important roles in most ecosystems, research now focuses on quantifying the relative and interactive effects of resource and consumer control and on predicting how these forces 
determine producer standing biomass, productivity, tissue nutrient content and species diversity within and across ecosystems (Thayer et al. 1984, de Mazancourt and Loreau 2000, Borer et al. 2006, Burkepile and Hay 2006, Hillebrand et al. 2007, Gruner et al. 2008).

Marine ecosystems are threatened worldwide by anthropogenic activities, changes in land use patterns, deforestation and poor agricultural practices that have resulted in eutrophication of the coastal zone (Short and Wyllie-Echeverria 1996). These changes coupled with massive loss of herbivores (Jackson et al. 2001) are changing the strength of top-down and bottom-up forces in the marine environment (Hughes et al. 2003, Bellwood et al. 2004, Burkepile and Hay 2006). Thus, knowing how consumers and resource availability will affect the structure of the primary producer community is critical in understanding the community structure and functioning of marine ecosystems.

Most aquatic ecosystems, such as kelp forests, cattail marshes, and seagrass beds, are dominated by and dependent on one or a few key plant species (Bruno et al. 2003) that structure the whole ecosystem. Seagrasses are marine angiosperms that form extensive meadows in muddy to sandy substrate in shallow coastal areas (den Hartog 1970). Seagrass meadows are one of the most productive ecosystems in the world (Duarte and Chiscano 1999), achieving high primary production even in oligotrophic environments (Hemminga and Duarte 2000), and much of their primary production is exported to adjacent ecosystems (Duarte and Cebrian 1996). Seagrasses also provide a substrate for epiphytic microalgae, whose production often equal or exceed that of the host macrophytes (Penhale 1977, Borum 1985, Moncreiff and Sullivan 2001). Many 
grazers feed on the epiphytes (Duffy and Harvilicz 2001, Moncreiff and Sullivan 2001) but only a few animals feed directly on seagrasses (e.g. some fish, some gastropods, sea urchin, turtles and dugongs) (Williams 1988, Bowen 1997, Anderson 1998, Rose et al. 1999, Kirsch et al. 2002), however massive loss of seagrass biomass caused by dugongs, turtles, sea urchins has been reported (Williams 1988, Rose et al. 1999, Aragones and Marsh 2000).

Seagrass meadows provide a good system for testing the effects of nutrients and grazing because they are structured by resource availability (Fourqurean et al. 1992, Erftemeijer and Herman 1994, Duarte and Sandjensen 1996, Ferdie and Fourqurean 2004) and herbivory (Hay 1984, Valentine and Heck 1999, Armitage and Fourqurean 2006, Olsen and Valiela 2010). The responses of seagrasses to increased nutrient supply are species specific (Fourqurean et al. 2003) and herbivore feeding preference is determined by nutrient content of seagrasses (Goeker et al. 2005, Armitage and Fourqurean 2006).

I carried out a two-year experimental manipulation of fertilization and simulated grazing (clipping) in a mixed seagrass bed in Florida Bay. I measured the direct and interactive effects of fertilization and clipping on the elemental content, morphology, productivity and composition of the primary producers. I tested the following hypotheses:

1) Fertilization will increase the productivity of the primary producers while simulated grazing will decrease it.

2) Fertilization will increase the leaf size and absolute abundance of some of the primary producers and change the community composition; 
3) Simulated grazing will decrease the leaf size and absolute abundance of some of the primary producers and change community composition; and

4) The impacts of fertilization and grazing on the primary producers are interactive. Grazing will dampen the effects of fertilization whereas; the negative effects of grazing will be ameliorated in the fertilized plots.

\section{METHODS}

\section{Site Description}

South Florida has the largest continuous seagrass meadows in the US, and one of the most well-documented seagrass communities in the world. Seagrass communities are found from the mangrove-lined estuaries of Florida Bay to the back-reef areas and open continental shelf waters (Fourqurean et al. 2002). Seagrasses are the dominant primary producer in the coastal areas of South Florida. Macroalgal biomass is less than seagrass biomass in this area (Zieman et al 1989). The three most common seagrass species are Thalassia testudinum, Syringodium filiforme, and Halodule wrightii, and the four macroalgal genera that have the greatest distribution in Florida Bay are Halimeda, Laurencia, Penicillus and Acetabularia (Zieman et al. 1989). The grazer community of seagrass beds in Florida bay consists of manatees, fish (parrotfishes and pinfish), sea urchins and turtles (Rose et al. 1999, Valentine and Heck 1999, Kirsch et al. 2002).

Experimental design

The experiment started in August 2007 and was terminated in July 2009. Experimental plots $\left(1 \mathrm{~m}^{2}\right)$ were established in a shallow water $(1.5 \mathrm{~m})$ seagrass meadow comprised of $T$. testudinum, $S$. filiforme and $H$. wrightii growing in a muddy sand 
sediment on the southwestern side of Florida Bay (N 24 51.01, W 80 53.190). The plots were situated $1 \mathrm{~m}$ apart in a $3 \times 3$ factorial design: 3 fertility levels (control (C), medium NP (1F) and high NP (2F) x 3 simulated grazing intensities (biomass removal, 0, 25 and $50 \%$ of the $1 \mathrm{~m}^{2}$ plot $(1 \mathrm{G}$ and $\left.2 \mathrm{G})\right) \times 5$ replicates for each treatment $=45$ plots. Nitrogen was added into the sediment using slow release nitrogen fertilizer pellets (Polyon ${ }^{\mathrm{TM}}$, Purcell Technologies Inc., 38-0-0) and phosphorus was added as granular phosphate rock (Multifos ${ }^{\mathrm{TM}}$, IMC Global, $\left.\mathrm{Ca}_{3}\left(\mathrm{PO}_{4}\right)_{2}, 18 \% \mathrm{P}\right)$. Fertilization and clipping were carried out every two months. The loading rate in the $1 \mathrm{~F}$ plots was $2.4 \mathrm{mg} \mathrm{N} \mathrm{d}^{-1}$ and $80 \mu \mathrm{g} \mathrm{P} \mathrm{d}^{-1}$ and in the $2 \mathrm{~F}$ plots was $4.8 \mathrm{mg} \mathrm{N} \mathrm{d}^{-1}$ and $160 \mu \mathrm{g} \mathrm{P} \mathrm{d}^{-1}$. These loading rates are four and eight times the nitrogen and phosphorus requirement of T. testudinum, which has the lowest nutrient requirement among the three species (Fourqurean et al. 1992). Since the N and P requirement of $H$. wrightii, which has the highest nutrient requirement among the three species, is twice and four times that of T. testudinum (Fourqurean et al. 1992), these loading rates will ensure that the nutrient requirements of all three species are met. Turtle grazing was simulated by clipping of aboveground biomass of the three seagrass species with stainless steel garden shears to about $5 \mathrm{~cm}$ above the sediment leaving the meristems on the buried horizontal rhizome intact. . I chose to simulate turtle grazing because turtles have been reported to graze on all three seagrass species (Mortimer 1981, Williams 1988). Turtles have also been observed to create discrete grazing plots in seagrass beds and return to these plots to harvest new growth (Bjorndal 1980). I subdivided the one square meter plot into sixteen $0.25 \times 0.25 \mathrm{~cm}$ quadrats. Then I clipped the above-ground biomass in 8 and 16 randomly chosen $0.25 \times 0.25$ qaudrats for the medium $(25 \%)$ and high $(50 \%)$ grazed plots, respectively. I did not intend to clip the macroalgae but some of 
them were removed in the process of clipping the seagrass leaves. The seagrass leaves were clipped every two months.

Experimental sampling

Leaf growth rate of $T$. testudinum was measured four times during the duration of the experiment and S. filiforme leaf growth rate was measured once in all plots. Three shoots of $T$. testudinum were randomly chosen in each plot to estimate leaf growth using a modified leaf marking technique of (Zieman 1974), and ten shoots of S. filiforme were randomly chosen to estimate leaf growth rate using the emergent leaf technique (Schwarzschild et al. 2008). Leaf growth measurements were taken on clipped shoots in the grazed plots. The plant leaves were marked immediately after nutrient addition and clipping. The shoots were collected for leaf growth rate measurements after 15 days. These techniques allowed us to calculate the absolute growth rate (AGR), relative growth rate (RGR) and plastochron interval. For T. testudinum, leaf absolute growth rate is defined as the increment in leaf length per short shoot per day while leaf relative growth rate is the increase in leaf length per day per unit of leaf length. For S. filiforme, the leaf absolute growth rate is defined as the increment in leaf length per day. The leaf plastochron interval is the time interval between the initiation of successive leaves.

At the termination of the experiment, three T. testudinum and 15 S. filiforme shoots were collected at each plot, placed in ice and transported to the laboratory. Morphological measurements of the leaves of T. testudinum (length and width) and $S$. filiforme (leaf length) shoots were recorded. The epiphytes on the leaf material of each species were gently scraped with a razor blade, dried at $70^{\circ} \mathrm{C}$, weighed, ground to a fine 
powder and analyzed for carbon (C), nitrogen (N) and phosphorus (P). I did not collect $H$. wrightii shoots because their small size would require collecting so much material that the composition of the plots could be altered. For each species within each plot, seagrass leaf material was pooled. Since plant tissue stoichiometry can be used as an indicator of the fertility of the ecosystem (Atkinson and Smith 1983), the C:N:P data were used to interpret competitive interactions among the constituent species. Carbon and nitrogen content were determined using a $\mathrm{CHN}$ analyzer. Phosphorus content was determined by a dry-oxidation, acid hydrolysis extraction followed by colorimetric analysis (Fourqurean et al. 1992a). Elemental content and ratios were calculated on a dry weight and mole:mole basis, respectively. The percent cover of all primary producers (T. testudinum, S. filiforme, H. wrightii, Halimeda and Penicillus) per square meter was measured using a modified Braun-Blanquet method (Braun-Blanquet 1972, Fourqurean et al. 2001). The result of this technique is a score of relative cover, in which cover is defined as the fraction of the bottom that is obscured by specific benthic taxa when viewed by a diver from directly above. Score values were as follows: 0 , absent; $1,<5 \%$ cover; $2,5-25 \%$ cover; $3,25-50 \%$ cover; $4,50-75 \%$ cover; $5,75-100 \%$ cover.

\section{ANALYSIS}

Leaf elemental content, leaf morphology, leaf biomass, leaf growth rate and absolute cover of the seagrasses were tested using a full factorial 2-way ANOVA (nutrient, grazing and nutrient $\mathrm{x}$ grazing) (Proc GLM in SAS 9.2). If necessary, data were log-transformed to achieve normality (Kolmogorov-Smirnoff test) and homogeneity of variances (Bartlett's test). For factors with significant effects, I compared means using 
Tukey's test. The comparison was considered statistically significant at $p \leq 0.05$. When there was significant interaction between the effects of nutrient addition and grazing means of one factor were compared using Tukey's test separately at each level of the other factor and vice versa.

\section{RESULTS}

Leaf nutrient content

The leaf $\mathrm{N}$ content of $T$. testudinum and $S$. filiforme did not respond to fertilization (Figure 2.1a and c, Table 2.1). Fertilization increased the leaf P content of $T$. testudinum by 6 and $17 \%$ in the $1 \mathrm{~F}$ and $2 \mathrm{~F}$ plots, respectively (Figure 2.1b, Table 2.1). The P content of $S$. filiforme increased by 4 and $26 \%$ in the $1 \mathrm{~F}$ and $2 \mathrm{~F}$ plots, respectively (Figure 2.1d, Table 2.1). The increase in the P content of T. testudinum and S. filiforme in the fertilized plots resulted in a decrease in their leaf C:P ratio (Figure 2.2b and d, Table 2.1). The leaf $\mathrm{C}: \mathrm{N}$ ratio of $T$. testudinum decreased in the enriched plots but there was no effect of fertilization on leaf C:N ratio of $S$. filiforme (Figure 2.2a and c, Table 1). The leaf $\mathrm{N}$ content of $S$. filiforme was 6 and $3 \%$ higher in the $1 \mathrm{G}$ and $2 \mathrm{G}$ plots, respectively but simulated grazing had no effect on leaf $\mathrm{N}$ content of T. testudinum (Figure 2.1a, and c, Table 2.1). The C:N ratio of T. testudinum and $S$. filiforme did not respond to simulated grazing (Figure 2.2a, and c, Table 2.1). Simulated grazing decreased the leaf P content of $T$. testudinum by 13 and $8 \%$ in the $1 \mathrm{G}$ and $2 \mathrm{G}$ plots, respectively but had no effect on the P content of $S$. filiforme (Figure $2.1 \mathrm{c}$ and $\mathrm{d}$, Table 2.1). The decrease in the P content of T. testudinum in the clipped plots caused an increase in its leaf C:P ratio (Figure 2.2b, Table 2.1). Clipping had no effect on the leaf C:P ratio of S. filiforme (Figure 2.2d, Table 
2.1). There were no interactive effects of grazing and fertilization on the elemental content of T. testudinum and S. filiforme: grazing had the same relative effect on elemental content across all levels of fertility and fertilization had the same relative effects across all levels of grazing (Figure 2.1 and 2.2, Table 2.1).

Morphology of seagrasses

The leaf area and leaf mass of T. testudinum did not respond to fertilization, or simulated grazing (Figure 2.3a and b, Table 2.1). The leaf length of S. filiforme increased by 44 and $61 \%$ in the $1 \mathrm{~F}$ and $2 \mathrm{~F}$ plots, respectively (Figure $2.3 \mathrm{c}$, Table 2.1 ). Clipping caused a decrease in the leaf mass of S. filiforme by 44 and $24 \%$ in the $1 \mathrm{G}$ and $2 \mathrm{G}$ plots, respectively but did not affect the leaf length of $S$. filiforme (Figure 2.3c and d, Table 2.1). There were no interactive effects of grazing and fertilization on the leaf length and leaf mass of T. testudinum and S. filiforme: grazing had the same relative effect on leaf length and leaf mass across all levels of fertility and fertilization had the same relative effects across all levels of grazing (Figure 2.3c and d, Table 2.1)

Growth rate of seagrasses

The absolute growth rate (AGR), relative growth rate (RGR) and leaf plastochron interval (PI) of T. testudinum did not respond to fertilization (Figure 2.4, Table 1).

Simulated grazing decreased the absolute growth rate of $T$. testudinum by 52 and $54 \%$ in the $1 \mathrm{G}$ and $2 \mathrm{G}$ plots, respectively but increased its relative growth rate by 330 and $400 \%$ in the $1 \mathrm{G}$ and $2 \mathrm{G}$ plots, respectively (Figure $2.4 \mathrm{a}$ and $\mathrm{b}$, Table 1). Simulated grazing had no effect on the leaf PI of T. testudinum (Figure 2.4c Table 1). Fertilization had no effect on the absolute growth rate of S. filiforme (Figure 2.5a, Table 1). The absolute growth 
rate of S. filiforme decreased in the clipped but unfertilized plots (Figure 2.5a, F x G interaction, Table 2.1 , Tukeys test, $\mathrm{p}<0.05$ ). The leaf PI of $S$. filiforme significantly increased in the fertilized plots, it was $162 \%$ and $215 \%$ higher than the control in the $1 \mathrm{~F}$ and 2F plots respectively (Figure 2.5e, Table 2.1). Clipping decreased the absolute growth rate of S. filiforme (Figure 2.5a, Table 2.1) but had no effect on leaf PI (Figure 2.5b, Table 2.1). S. filiforme leaf PI did not respond to the interactive effects of fertilization and simulated grazing.

Absolute abundance of primary producers

The absolute abundance of $T$. testudinum did not respond to fertilization or simulated grazing (Figure 2.6a, Table 2.1). The absolute abundance of S. filiforme increased by $39 \%$ and $64 \%$ in the $1 \mathrm{~F}$ and $2 \mathrm{~F}$ plots, respectively (Figure 2.6b, Table 2.1). Grazing decreased the absolute abundance of S. filiforme by $24 \%$ and $45 \%$ in the $1 \mathrm{G}$ and $2 \mathrm{G}$ plots, respectively (Figure 2.6b, Table 2.1). Fertilization had a larger effect on the absolute abundance of S. filiforme in unclipped plots than in the clipped plots. (Figure 2.6b, Table 2.1, Tukey's test, $\mathrm{p}<0.05$ ). The absolute abundance of $H$. wrightii decreased by $58 \%$ and $110 \%$ in the $1 \mathrm{~F}$ and $2 \mathrm{~F}$ plots, respectively (Figure 2.6c, Table 2.1 ). Fertilization increased the absolute abundance of Halimeda by $28 \%$ and $46 \%$ in the $1 \mathrm{~F}$ and 2F plots, respectively (Figure 2.6d, Table 2.1). Penicillus did not respond to fertilization (Figure 2.6e, Table 2.1). The absolute abundance of $H$. wrightii, Halimeda and Penicillus did not respond to simulated grazing and there were no interactive effects of fertilization and simulated grazing (Figure 2.6c, $d$ and e, Table 2.1). 


\section{DISCUSSION}

The results of the two-year fertilization and clipping experiment suggest that fertilization and grazing are key variables that could influence the patterns and processes in marine ecosystems subject to anthropogenic activities. Fertilization and simulated grazing had strong but opposite effects on tissue nutrient content, growth rate, and species abundance of the seagrass community in South Florida. Fertilization did not affect the $\mathrm{N}$ content of $T$. testudinum and $S$. filiforme. This suggests that there is enough $\mathrm{N}$ in the control plots to meet the requirements of these species. This concurs with the results of a fertilization experiment conducted by Armitage et al. (2005) in Florida Bay that shows enrichment had no effect on the $\mathrm{N}$ content of seagrasses. Although fertilization did not significantly affect the $\mathrm{N}$ content of $T$. testudinum, the C: $\mathrm{N}$ ratio did decrease, indicating that either fertilization increased availability of $\mathrm{N}$ to the plants or that plants have become carbon limited. Fertilization increased the P content and decreased the C:P ratio of $T$. testudinum and $S$. filiforme but there was no concomitant increase in their growth rate. Experiments conducted in the Florida Keys (Ferdie and Fourqurean 2004) and Jobos bay, Puerto Rico (Olsen and Valiela 2010) showed a similar lack of growth response from $T$. testudinum to fertilization. This suggests that $\mathrm{P}$ availability has increased in the fertilized plots but other factors such as light have become limiting, so there was no significant increase in the growth rate of $T$. testudinum and $S$. filiforme.

It has been demonstrated that the intensity of aboveground competition increases with increasing fertility and plant density (Grime 1979, Reader and Best 1989, Schwinning and Weiner 1998, Fargione and Tilman 2002). When plants are not nutrient 
limited and light becomes limiting, plants tend to allocate more biomass to photosynthetic tissues (Bloom et al. 1985). In the enriched plots, there was an increase in leaf length, leaf mass and absolute abundance of S. filiforme, although there was no increase in the absolute growth rate of $S$. filiforme. I might have failed to quantify other components of growth (e.g. biomass production) because the leaf emergent technique only measures increments in length in S. filiforme. The increase in leaf size and abundance of $S$. filiforme is a competitive advantage in light capture over the other species. In addition, the fast growing vertical rhizomes of S. filiforme can extend above the sediment surface into the water column, allowing it to form a dense multi-layered canopy (Marba et al. 1994, Kenworthy and Schwarzschild 1998) that could shade the other species. Kenworthy and Schwarzchild (1998) reported that over 70\% the aboveground biomass of S. filiforme is comprised of non-photosynthetic stems and sheaths. The benefit of being able to grow high into the water column could have associated physiological cost, which could explain the lack of leaf growth response of $S$. filiforme to fertilization.

In seagrass meadows, canopy structure and leaf density can strongly attenuate light, which can result in a gradient of photosynthetic activity along the length of a leaf. Seagrasses grow from a basal meristem, an area that has the least chlorophyll and also receives the least amount of light (Enriquez et al. 2002). The longer leaf PI of S. filiforme in the fertilized plots could be an adaptive mechanism to compete for light since mature leaves are more efficient in light capture than the new emerging leaf. Increased leaf longevity could have disadvantages because photosynthetic rate declines with leaf age 
(Field and Mooney 1983, Kitajima et al. 1997). Gallegos et al. (1994) reported that the leaf PI of S. filiforme increased with greater shoot density. A review by Walters and Reich (1999) showed that shade tolerant broadleaved evergreen species have longer leaf life span than shade intolerant species.

Resource competition could determine the composition of a plant community (Tilman 1982). The abundance of T. testudinum was not affected by the increase in the abundance of $S$. filiforme, likely due to its low nutrient requirement (Fourqurean et al. 1992) well-developed root and rhizome system (van Tussenbroek et al. 2006) that can efficiently absorb nutrients, and flat strap-like leaves that can grow as tall the $S$. filiforme canopy. The flat strap-like leaves of T. testudinum aid in light capture allowing it to compete with $S$. filiforme for light. This is particularly important because $T$. testudinum has a higher light requirement than the other co-occurring species (Wiginton and McMillan 1979). The decrease in the abundance in the fertilized plots of $H$. wrightii, a plant with higher nutrient requirement (Fourqurean et al. 1995) and smaller in size relative to the other species must be due to its inability to compete efficiently for light. Burd and Dunton (2001) reported that light was a major factor controlling H. wrightii productivity. The absolute abundance of the macroalgae Halimeda increased in response to fertilization. Littler et al. (1988) reported that Halimeda is adapted to take advantage of episodic nutrient supply and achieve light-saturated photosynthesis at very low irradiance. Their study also showed that this genus requires low light to reach photosynthetic compensation point and are efficient in using low photon flux densities. 
Furthermore, the results of a study by Davis and Fourqurean (2001) suggest that Halimeda competes with seagrasses for nutrients more than for light.

McNaughton (1979) proposed that partial defoliation could enhance resource demand in the meristems of the shoots that stimulates photosynthetic rate per unit of leaf area. In addition, leaf clipping could allow more efficient light use by reducing selfshading (McNaughton 1979, Hilbert et al. 1981), although Belsky et al. (1993) argued that removal of foliage could lead to decrease in productivity. The observed increase in the relative growth rate of $T$. testudinum could be compensatory growth in response to simulated grazing (McNaughton 1979) fueled by stored resources from belowground plant structures. Clipping of the leaves resulted in a loss of $\mathrm{P}$ and an increase in $\mathrm{C}: \mathrm{P}$ ratio of T. testudinum, likely contributing to the observed decrease in its absolute growth rate in response to simulated grazing. Although the leaf mass of S. filiforme significantly decreased in the clipped plots, the leaf length was not affected. This could be a mechanism to allow it to compete with T. testudinum for light since grazing had no significant effect on T. testudinum.

Several studies have reported a correlation between total leaf nitrogen and photosynthetic capacity (Gulmon and Chu 1981, Field and Mooney 1986, Evans 1989). Nitrogen is an important component of the proteins of the Calvin cycle and thylakoids of leaves. The increase in $\mathrm{N}$ allocation to the leaves of $S$. filiforme in the clipped plots is probably in response to the loss of foliage. An increase in tissue $\mathrm{N}$ content in seagrasses in response to simulated grazing has been documented (Moran and Bjorndal 2007, Vergés et al. 2008). But it appears that the increase in $\mathrm{N}$ content of the leaves of $S$. 
filiforme and increased light availability to the clipped shoots did not compensate for the loss of photosynthetic tissues resulting in a decrease in absolute growth rate. This may be due to the lower carbon uptake rate of S. filiforme $\mathrm{mg}\left(1.74( \pm 0.26) \mathrm{C} \mathrm{gDW}^{-1} \mathrm{~h}^{-1}\right)$ compared to those of $H$. wrightii $(2.33( \pm 0.28))$ and $T$. testudinum $(2.02( \pm 0.12))$ (Zieman et al. 1989). Carbon-limitation in S. filiforme could be exacerbated by the loss of leaves due to clipping. This reduced growth rate resulted in a decrease in the absolute cover of $S$. filiforme in the clipped plots. The marked decrease in absolute cover of S. filiforme in clipped plots that were unfertilized plots could be due to increased competition from the other species that did not respond to the interactive effects of fertilization and clipping. The ability of plants to compensate for biomass loss due to grazing decreases with increasing competition from other plants and as nutrient levels decrease (Maschinski and Whitham 1989).

Grazing prevents competitive exclusion through biomass removal of the dominant species. It seems the decrease in S. filiforme cover in the clipped plots allowed the other species to persist. The absolute abundance of T. testudinum, H. wrightii, Halimeda and Penicillus was not affected by clipping. The result of a meta-analysis by Burkepile and Hay (2006) showed that nutrient enrichment did not affect $T$. testudinum in the presence or absence of herbivores. These results suggest two things: first, the removal of the dominant species by grazing under conditions of high nutrient supply allows the other species to persist, and second, the negative impacts of grazing on seagrass biomass can be ameliorated by the positive effects of nutrient addition on plant growth.

The species-specific response to fertilization and simulated grazing in this study 
could have important implications on ecosystem structure and function. The coexistence of species possessing different plant traits and strategies that allows for efficient exploitation of all available resources will increase ecosystem productivity (Tilman et al. 1997, Hooper et al. 2005). Thus, a more diverse seagrass community will perform better when subjected to increased nutrient loading and/or grazing. Species diversity has been shown to positively influence resilience and recovery after a perturbation or disturbance (Hooper et al. 2005).

Most published simulated grazing studies were conducted in monospecific seagrass beds (e.g. Wittmann and Ott 1982, Moran and Bjorndal 2005, Moran and Bjorndal 2007); this is the first study that evaluated the effects of simulated grazing in a mixed seagrass meadow. Fertilization increased competitive dominance within the primary producers while simulated grazing counteracted this effect by removal of the dominant species. The impact of simulated grazing on seagrass community structure would probably be greater if our grazing regime mimicked preferential grazing of herbivores on nutrient rich plants (Goecker et al. 2005, Armitage and Fourqurean 2006) or sustained grazing by turtles (Bjorndal 1980). This study also shows that if there is enough nutrient supply to support plant growth, grazing plots can sustainably support intense grazing pressure (Bjorndal 1980, Williams 1988). Our results thus provide some support for theoretical expectations that anthropogenic activities that alter grazer community structure may also affect the response of marine communities to nutrient perturbations. Future studies should address the direct and interactive effects of nutrient supply and preferential grazing on community structure and relate these changes to ecosystem functions. 
Table 2.1. ANOVA results of effects of nutrients and grazing on response variables measured after 24 months of fertilization and grazing. Significant effects (defined as $\mathrm{p} \leq$ $0.05)$ are designated in boldface type.

\begin{tabular}{|c|c|c|c|c|c|c|}
\hline \multirow[t]{2}{*}{ Response variables } & \multicolumn{2}{|c|}{ Nutrient $(\mathrm{F})$} & \multicolumn{2}{|c|}{ Grazing $(\mathrm{G})$} & \multicolumn{2}{|c|}{$F \times G$} \\
\hline & $\mathrm{F}_{45,2}$ & $\mathrm{P}$ & $\mathrm{F}_{45,2}$ & $\mathrm{P}$ & $\mathrm{F}_{45,4}$ & $\mathrm{P}$ \\
\hline \multicolumn{7}{|l|}{ Thalassia testudinum } \\
\hline Leaf $\mathrm{N}$ & 2.34 & 0.11 & 1.77 & 0.19 & 2.04 & 0.11 \\
\hline Leaf $P$ & 4.59 & 0.017 & 2.99 & 0.06 & 0.22 & 0.93 \\
\hline Leaf C:N & 3.93 & 0.028 & 2.92 & 0.07 & 1.65 & 0.18 \\
\hline Leaf C:P & 5.51 & 0.008 & 4.98 & 0.01 & 0.17 & 0.95 \\
\hline Leaf area & 0.51 & 0.61 & 0.41 & 0.67 & 1.23 & 0.31 \\
\hline Leaf mass & 0.29 & 0.75 & 0.64 & 0.53 & 1.14 & 0.35 \\
\hline Relative growth rate & 1.10 & 0.34 & 7.80 & 0.002 & 0.723 & 0.58 \\
\hline Absolute growth rate & 1.17 & 0.32 & 11.69 & $<0.001$ & 0.44 & 0.78 \\
\hline Leaf PI & 1.08 & 0.35 & 5.44 & 0.006 & 0.274 & 0.89 \\
\hline Absolute abundance & 1.08 & 0.35 & 1.08 & 0.35 & 0.46 & 0.77 \\
\hline \multicolumn{7}{|l|}{ Syringodium filiforme } \\
\hline Leaf $N$ & 1.53 & 0.23 & 3.46 & 0.04 & 1.19 & 0.33 \\
\hline Leaf $P$ & 17.35 & $<0.001$ & 0.43 & 0.65 & 0.39 & 0.81 \\
\hline Leaf CN & 2.01 & 0.15 & 2.84 & 0.07 & 0.26 & 0.91 \\
\hline Leaf CP & 13.86 & $<0.001$ & 0.32 & 0.73 & 1.03 & 0.40 \\
\hline Leaf length & 11.14 & $<0.001$ & 0.47 & 0.63 & 0.7 & 0.59 \\
\hline Leaf mass & 19.35 & $<0.001$ & 12.58 & $<0.001$ & 0.61 & 0.66 \\
\hline Leaf PI & 4.32 & 0.02 & 1.83 & 0.83 & 2.28 & 0.08 \\
\hline Absolute growth rate & 0.565 & 0.57 & 8.02 & 0.002 & 6.61 & 0.001 \\
\hline Absolute abundance & 20.67 & $<0.001$ & 12.67 & $<0.001$ & 3.01 & 0.03 \\
\hline \multicolumn{7}{|l|}{ Halodule wrightii } \\
\hline Absolute abundance & 5.36 & 0.016 & 0.88 & 0.43 & 0.65 & 0.63 \\
\hline \multicolumn{7}{|l|}{ Halimeda } \\
\hline Absolute abundance & 8.66 & 0.001 & 0.01 & 0.99 & 2.15 & 0.09 \\
\hline \multicolumn{7}{|l|}{ Penicillus } \\
\hline Absolute abundance & 0.73 & 0.49 & 0.41 & 0.67 & 0.61 & 0.66 \\
\hline
\end{tabular}



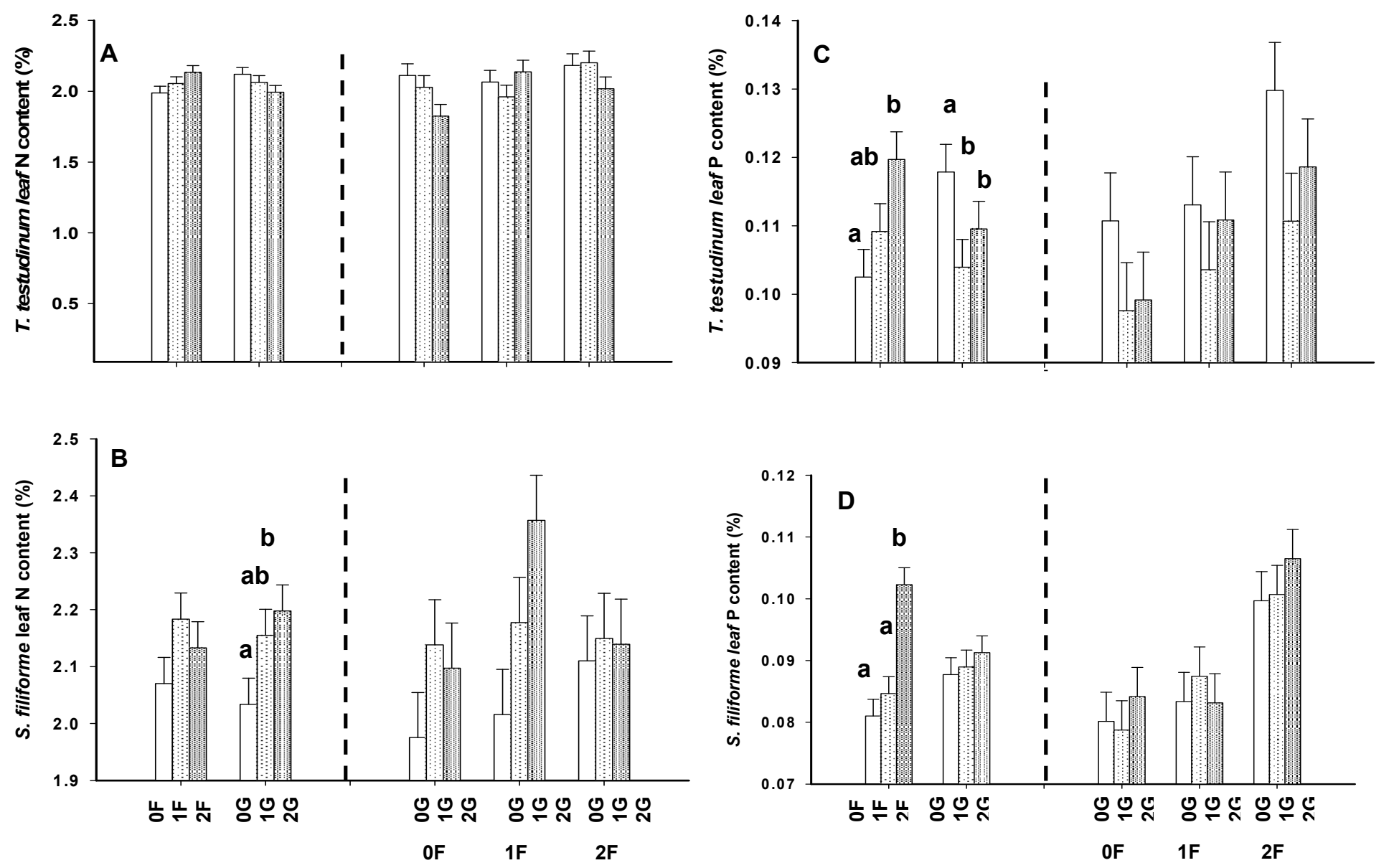

Main effects

Interaction

Main effects

Interaction

Figure 2.1 The direct and interactive effects of fertilization and simulated grazing on (A) T. testudinum leaf N, (B) T. testudinum leaf P, (C) $S$.

filiforme leaf N and (D) S. filiforme leaf P content as a percent of dry weight (means \pm standard error). Mean values in a group of bars followed by different letters are significantly different $(\mathrm{p}<0.05$, Tukey's HSD test) 

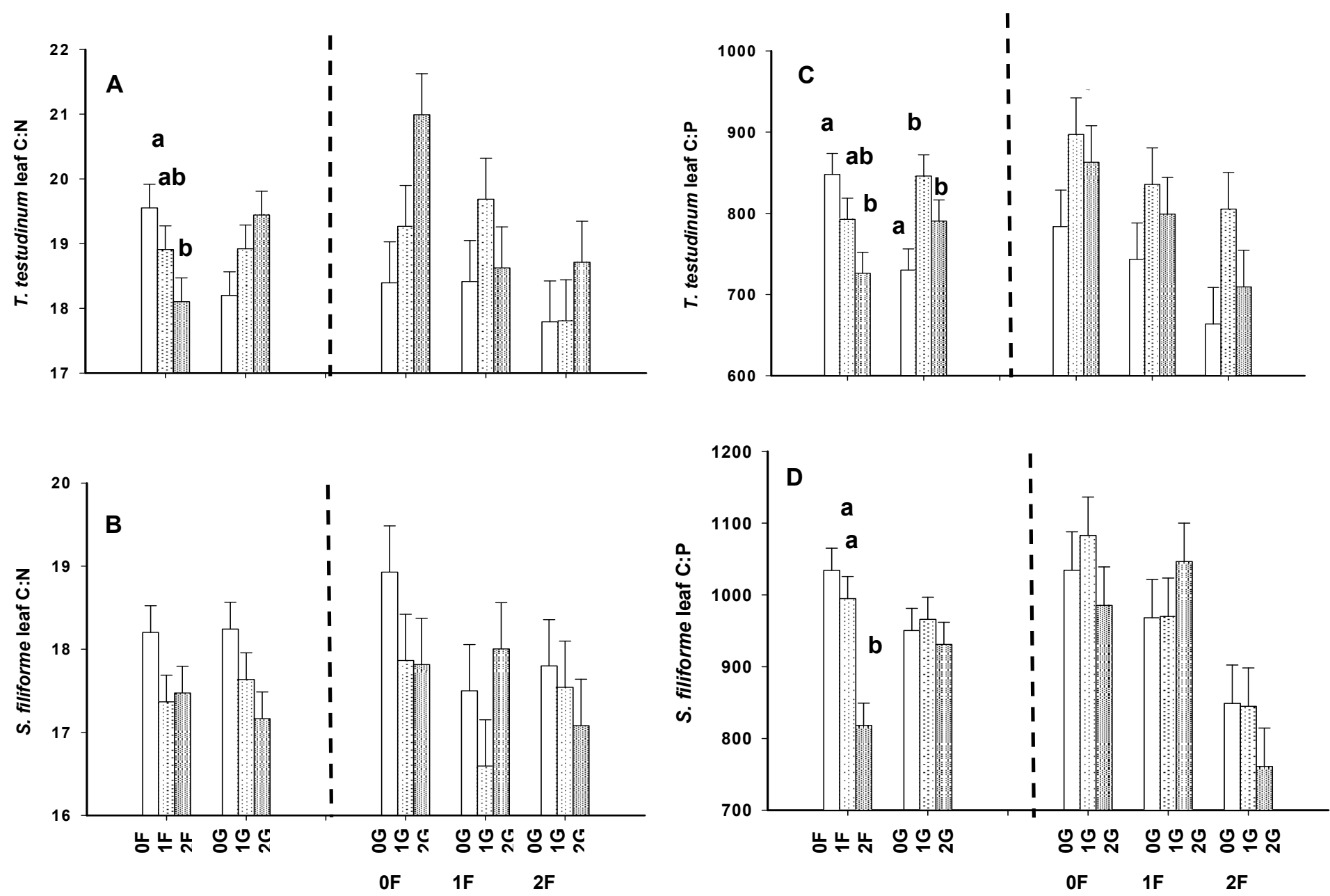

Main effects

Interaction

Main effects

Interaction

Figure 2. 2. The direct and interactive effects of fertilization and simulated grazing on (A) T. testudinum leaf C:N ratio, (B) T. testudinum leaf C:P ratio, (C) S. filiforme leaf C:N ratio and (D) S. filiforme leaf C:P ratio (means \pm standard error). Mean values in a group of bars followed by different letters are significantly different ( $\mathrm{p}<0.05$, Tukey's HSD test) 

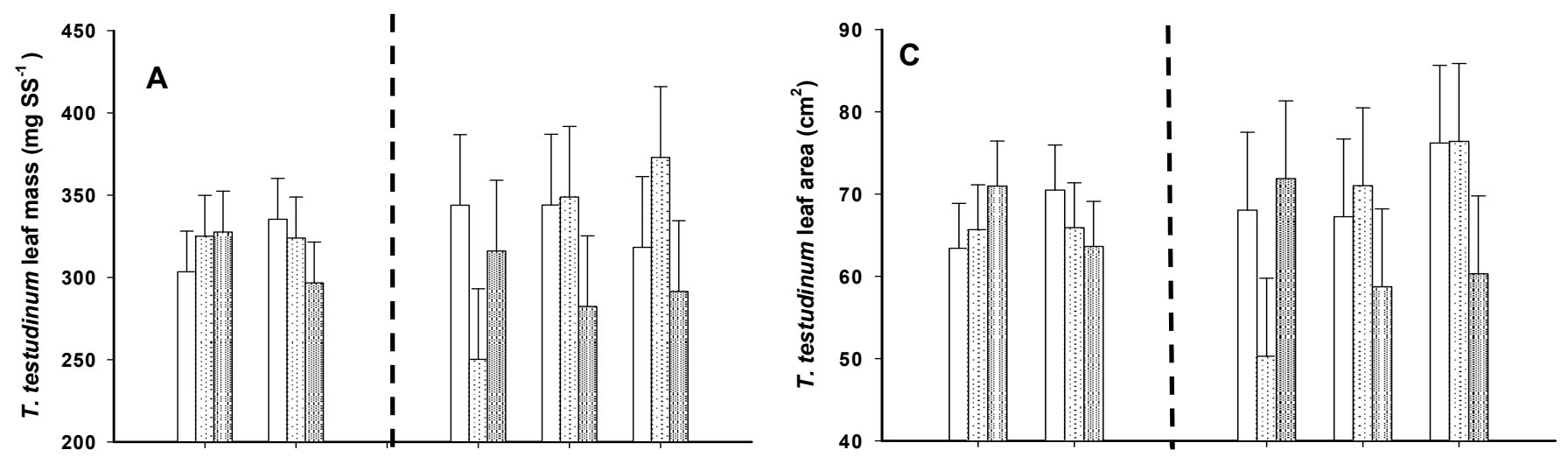

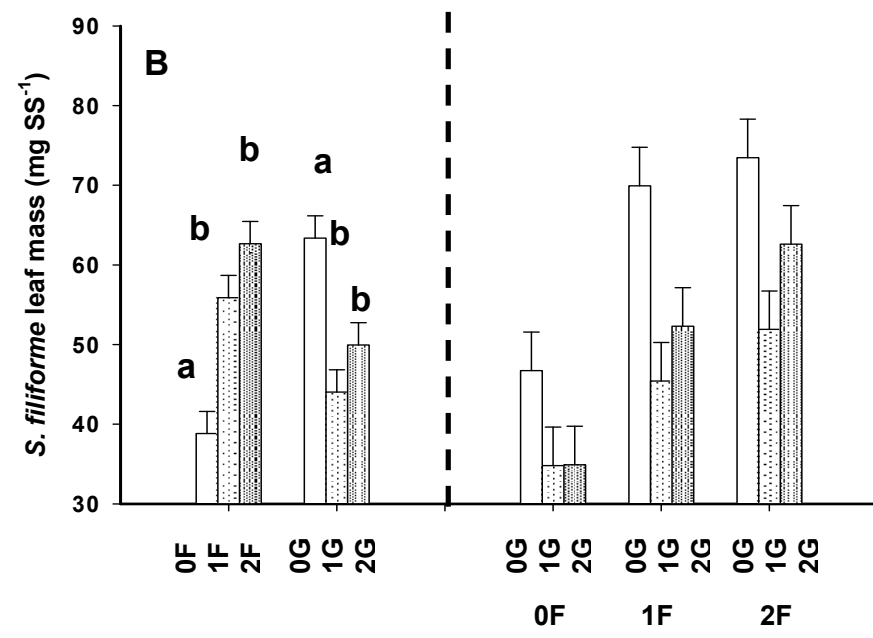

Main effects

Interaction

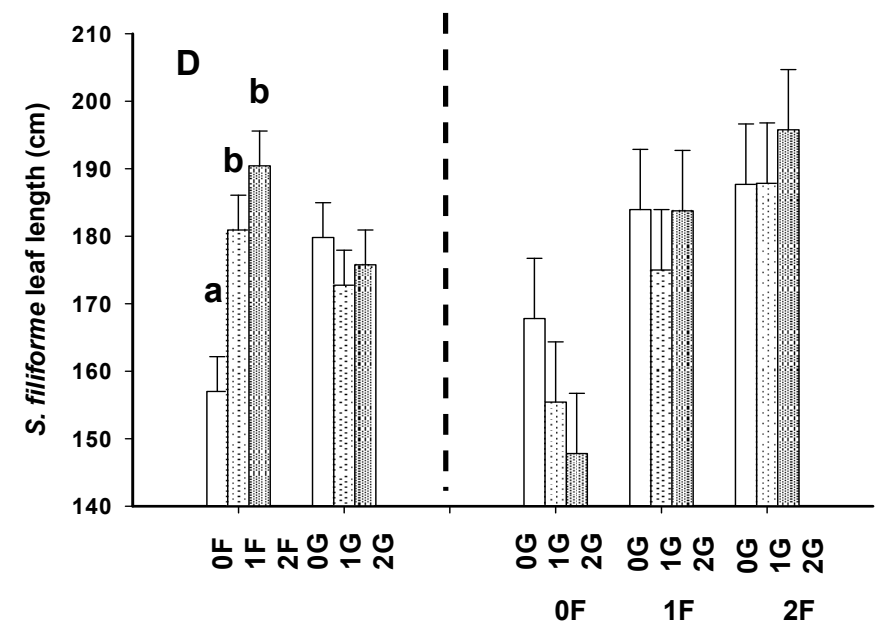

Main effects

\section{Interaction}

Figure 2.3. The direct and interactive effects of fertilization and simulated grazing on (A) T. testudinum leaf area, (B) T. testudinum leaf mass, (C) $S$. filiforme leaf length and (D) S. filiforme leaf mass (means \pm standard error). Mean values in a group of bars followed by different letters are significantly different ( $\mathrm{p}<0.05$, Tukey's HSD test) 

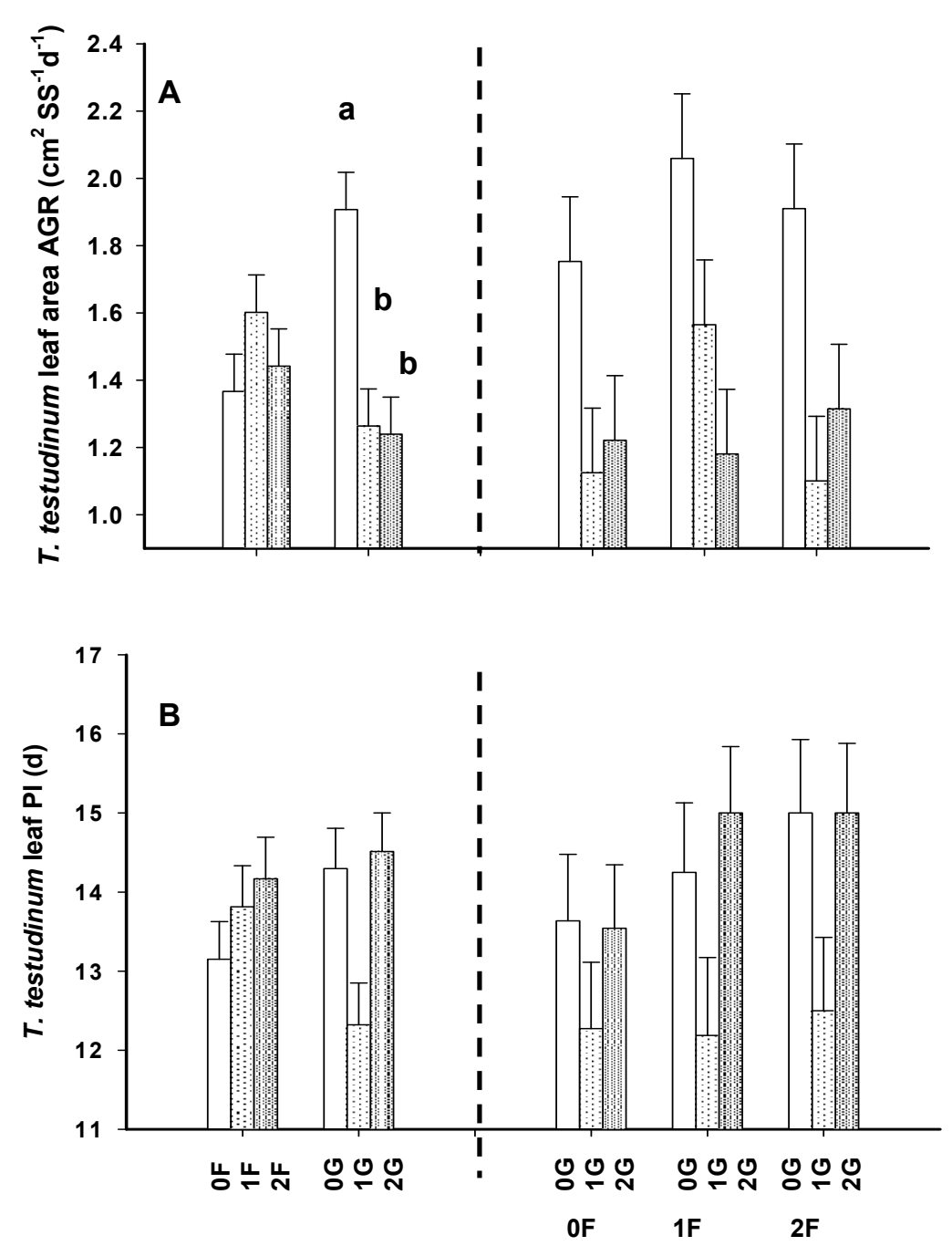

Main effects

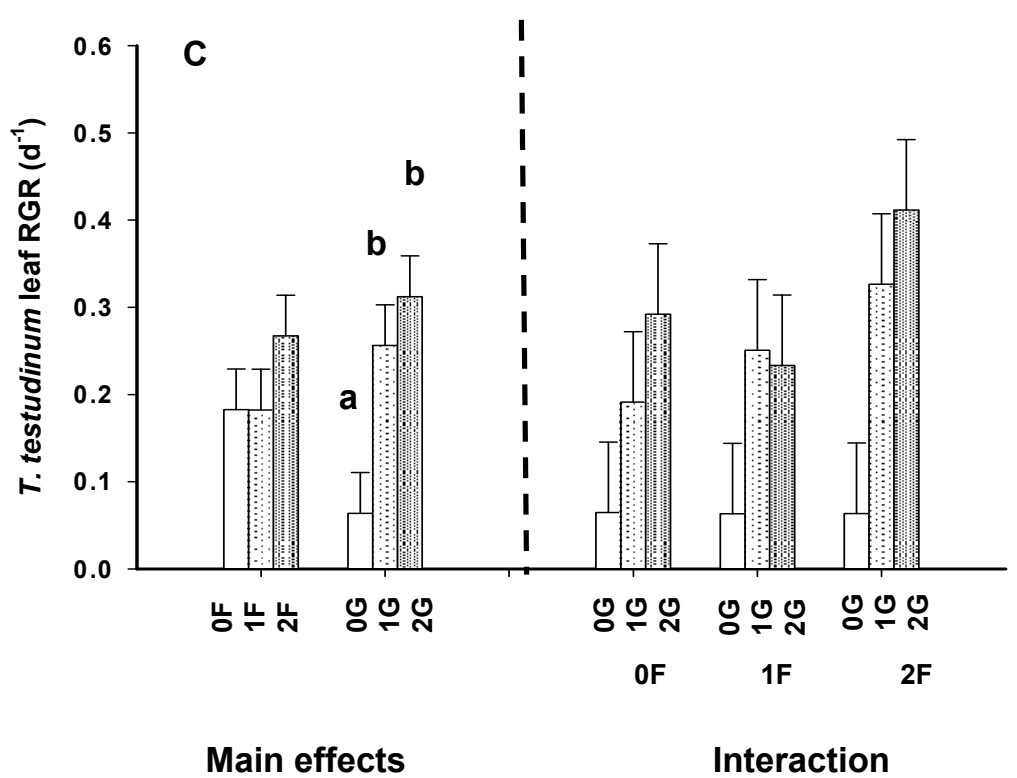

Figure 2.4. The direct and interactive effects of fertilization and simulated grazing on (A) T. testudinum leaf AGR, (B) T. testudinum leaf RGR, (C) T. testudinum leaf PI, (means \pm standard error). Mean values in a group of bars followed by different letters are significantly different $(p<0.05$, Tukey's HSD test) 

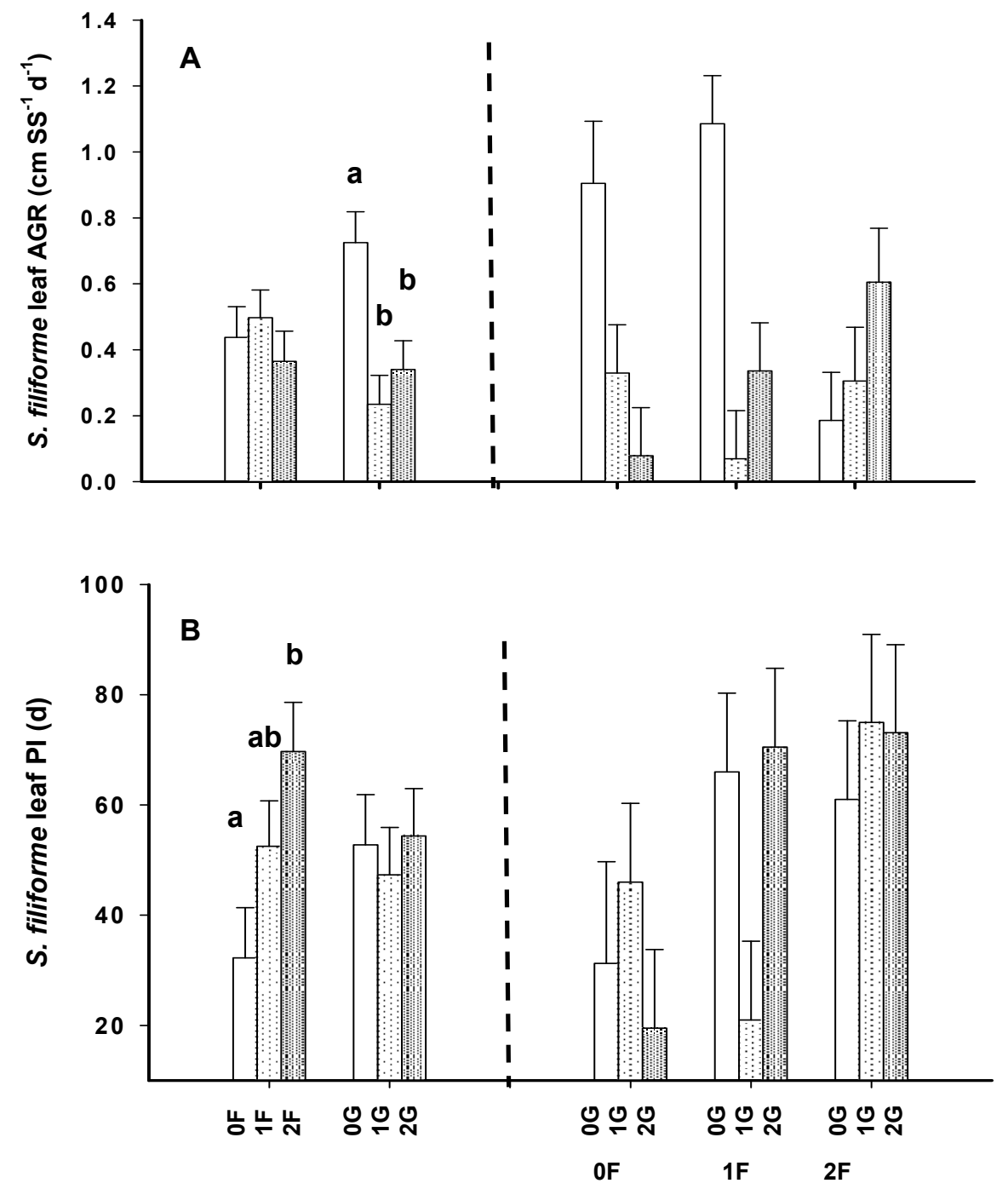

Main effects
Interaction
Figure 2.5. The direct and interactive effects of fertilization and simulated grazing on (A) S. filiforme leaf AGR and (B) $S$. filiforme leaf PI (means \pm standard error). Mean values in a group of bars followed by different letters are significantly different ( $<<0.05$, Tukey's HSD test) 

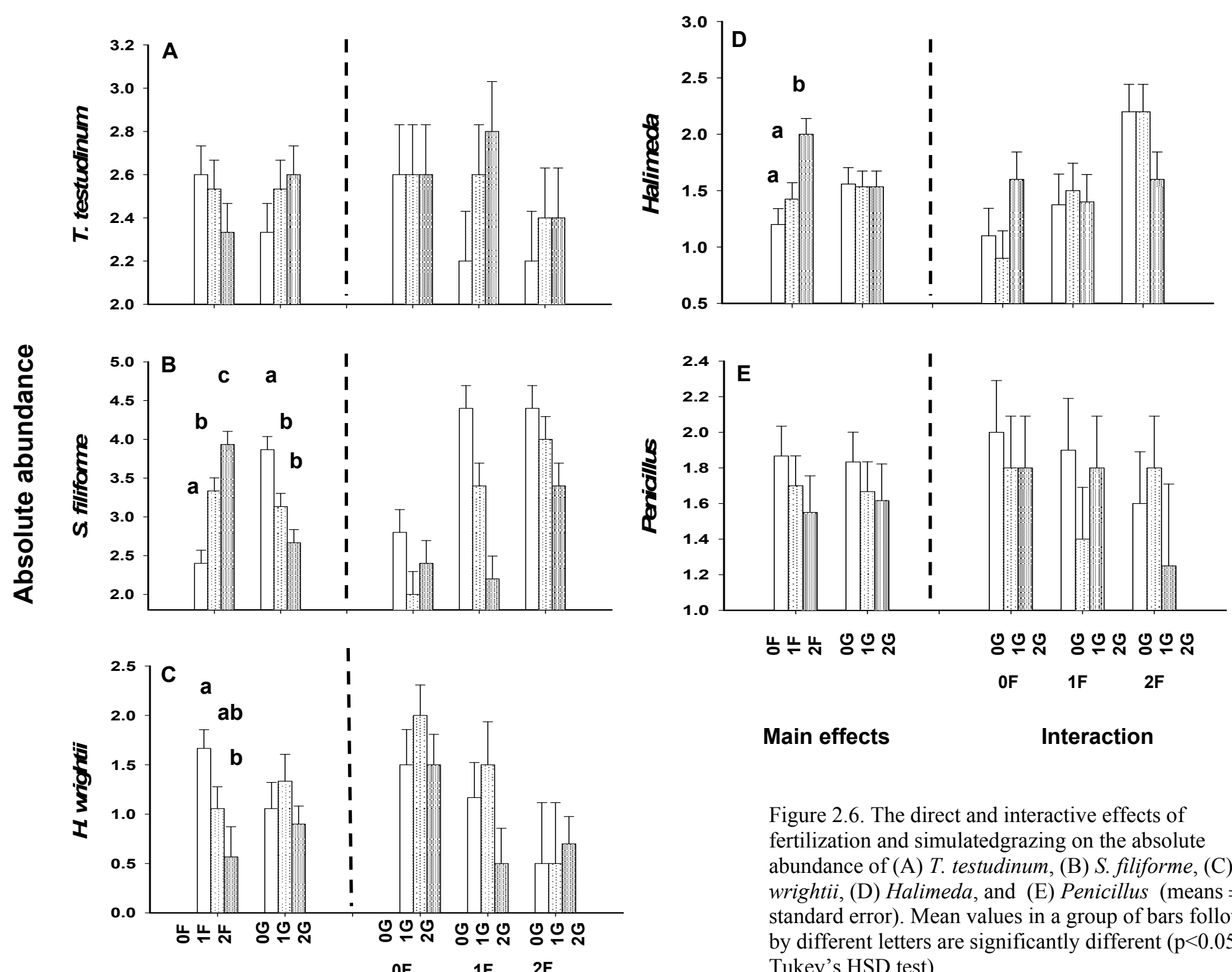

Main effects

\section{Interaction}

Figure 2.6. The direct and interactive effects of fertilization and simulatedgrazing on the absolute abundance of (A) T. testudinum, (B) S. filiforme, (C) $H$. wrightii, (D) Halimeda, and (E) Penicillus (means \pm standard error). Mean values in a group of bars followed by different letters are significantly different $(p<0.05$, Tukey's HSD test)

Main effects

Interaction 
CHAPTER 3: TEMPORAL CHANGE IN THE COMMUNITY STRUCTURE OF A SUBTROPICAL SEAGRASS BED IN RESPONSE TO THE DIRECT AND INTERACTIVE EFFECTS OF FERTILIZATION AND SIMULATED GRAZING

\section{INTRODUCTION}

Pervasive anthropogenic changes to coastal areas and consumer community structure pose a challenge to the ability of ecologists to predict responses of primary producers, plant community structure and ecosystem function to these changes. Nitrogen and phosphorus are known to limit primary production in coastal ecosystems (Elser et al. 2007). The input rates of nitrogen and phosphorus to coastal ecosystems have increased due to changes in land use pattern, agricultural practices and human activities along the coastal zone causing massive eutrophication (Bonsdorff et al. 1997, Boesch 2002).

Similarly, human-caused changes in the intensity of top-down control due to overfishing can change the standing biomass and composition of primary producers in coastal ecosystems (Jackson 2001, Boesch 2002).

Earlier studies pursued the effects of fertilization and herbivory independently but contemporary research suggests that these two variables interact (Hawkes and Sullivan 2001, Worm et al. 2002, Hillebrand 2003, Hartley and Mitchell 2005, Burkepile and Hay 2006, Olsen and Valiela 2010). With the common recognition that both resources and consumer impacts play important roles in controlling primary productivity and community structure research now focuses on quantifying the relative and interactive effects of these forces and in predicting how these forces determine producer standing biomass and community composition. Earlier studies have provided support for the positive effect of nutrient addition (Tilman 1990, Fridley 2002, Gruner et al. 2008) and 
herbivore removal on plant biomass (McNaughton 1985, Gruner et al. 2008). However both models and case studies offer conflicting predictions and evidence as to whether bottom-up and top-down factors should independently or interactively control plant community structure (Adler et al. 2001, Worm et al. 2002, Burkepile and Hay 2006, Hillebrand et al. 2007).

In this chapter, I present results of a two-year fertilization and simulated grazing experiment in a subtropical multi-specific seagrass bed. I used natural history information to explain the temporal changes in the plant community structure of a subtropical seagrass bed in response to the direct and interactive effects of fertilization and grazing. The competitive interactions among species following changes in nutrient supply play a critical role in determining the community response to eutrophication. Our results emphasize the important role of grazers in buffering moderate eutrophication effects and illustrate that shifts in species composition could influence community structure and function (Worm et al. 2000).

Fourqurean et al.’s (2003) species dominance-eutrophication gradient conceptual model predicts that the dominant species of primary producers in near-shore marine water of South Florida changes with changing nutrient concentration. The model predicts that with increasing nutrient supply, the dominant species will shift from T. testudinum, $S$. filiforme, $H$. wrightii, $R$. maritima, macroalgae, and finally to microalgae. I presented a model in Chapter 1 stating that this trajectory could be delayed if there are enough grazers to prevent the dominance of a few species. In a seagrass bed, I hypothesize that the following scenarios could occur: 1) an increase in nutrient loading in the absence of 
herbivory will lead to the dominance of a species capable of exploiting the increased nutrient availability; 2) an increase in grazing pressure without an increase in nutrient supply will lead to a decrease in seagrass abundance, and only species that are resistant or tolerant to grazing will persist, and 3) the interactive effects of fertilization and simulated grazing will prevent one species from dominating the community, i.e. clipping will prevent competitive exclusion at higher nutrient supply.

\section{METHODS}

Site Description

Seagrasses are the dominant primary producer in the coastal areas of South Florida. Macroalgal biomass is less than seagrass biomass in this area (Zieman et al 1989). The three most common seagrass species are Thalassia testudinum, Syringodium filiforme, and Halodule wrightii, and the four macroalgal genera that have the greatest distribution in Florida Bay are Halimeda, Laurencia, Penicillus and Acetabularia (Zieman et al. 1989). Fourqurean et al.'s (2003) species-dominance model predicts that at low nutrient availability, T. testudinum will dominate and $H$. wrightii will dominate at a higher nutrient supply. I assume that the background nutrient concentration in the study site is in the intermediate range as evidenced by the presence of all three seagrass species. There is very low herbivory in the area (personal obs.).

Experimental design and treatments

The experiment started in August 2007 and was terminated in July 2009. Experimental plots $\left(1 \mathrm{~m}^{2}\right)$ were established in a shallow water $(1.5 \mathrm{~m})$ seagrass meadow comprised of Thalassia testudinum, Syringodium filiforme, and Halodule wrightii 
growing in a muddy sand sediment on the southwestern side of Florida Bay (N 24 51.01, W 80 53.190). The plots were situated $1 \mathrm{~m}$ apart in a $3 \times 3$ factorial design: 3 fertility treatments (control (C), medium NP (1F) and high NP (2F) x 3 simulated grazing intensities (clipping) $(0,25$ and $50 \%$ biomass removal of the plot $(1 \mathrm{G}$ and $2 \mathrm{G})) \times 5$ replicates for each treatment $=45$ plots. Nitrogen was added into the sediment using slow release nitrogen fertilizer pellets (Polyon ${ }^{\mathrm{TM}}$, Purcell Technologies inc., 38-0-0) and phosphorus was added as granular phosphate rock (Multifos ${ }^{\mathrm{TM}}$, IMC Global, $\mathrm{Ca}_{3}\left(\mathrm{PO}_{4}\right)_{2}$, $18 \% \mathrm{P})$. Fertilization and simulated grazing were carried out every two months. The fertilizer loading rate in the $1 \mathrm{~F}$ plots was $2.4 \mathrm{mg} \mathrm{N}$ day $^{-1}$ and $80 \mu \mathrm{g} \mathrm{P}$ day ${ }^{-1}$ and in the $2 \mathrm{~F}$ plots was $4.8 \mathrm{mg} \mathrm{N}$ day $^{-1}$ and $160 \mu \mathrm{g} \mathrm{P}$ day $^{-1}$. These loading rates are four and eight times the nitrogen and phosphorus requirement of $T$. testudinum, which has the lowest nutrient requirement among the three species (Fourqurean et al. 1992). Since the $\mathrm{N}$ and $\mathrm{P}$ requirement of $H$. wrightii, which has the highest nutrient requirement among the three species, is twice and four times that of T. testudinum (Fourqurean et al. 1992), these loading rates ensured that the nutrient requirements of all three species were met. Turtle grazing was simulated by clipping of aboveground biomass of the three seagrass species with stainless steel garden shears to about $5 \mathrm{~cm}$ above the sediment leaving the meristems intact. I chose to simulate turtle grazing because turtles have been reported to graze on all three seagrass species (Mortimer 1981, Williams 1988). Turtles have also been observed to create discrete grazing plots in seagrass beds and return to these plots to harvest new growth (Bjorndal 1980). I subdivided the one square meter plot into sixteen $0.25 \times 0.25$ $\mathrm{cm}$ quadrats. Then I clipped the above-ground biomass in eight and sixteen randomly chosen $0.25 \times 0.25$ qaudrats for the medium (25\%) and high (50\%) grazed plots, 
respectively. I did not intend to clip the macroalgae but some of them were removed in the process of clipping the seagrass leaves. The seagrass leaves were clipped every two months.

\section{Experimental sampling}

The experimental plots were sampled every two months and the following plant response variables were measured at all sampling events: abundance of seagrasses and macroalgae; morphology and leaf elemental content of T. testudinum and S. filiforme. The percent cover of all primary producers (T. testudinum, S. filiforme, H. wrightii, Halimeda and Penicillus) per square meter was measured using a modified BraunBlanquet method (Braun-Blanquet 1972, Fourqurean et al. 2001). The result of this technique is a score of relative cover, in which cover is defined as the fraction of the bottom that is obscured by specific benthic taxa when viewed by a diver from directly

above. Score values were as follows: 0 , absent; $1,<5 \%$ cover; $2,5-25 \%$ cover; $3,25-50 \%$ cover; $4,50-75 \%$ cover; $5,75-100 \%$ cover. The relative cover of primary producers was measured prior to clipping because I was interested in evaluating the responses of the plants to simulated grazing. I measured canopy height at three highest points in each plot using a ruler.

I calculated H (Shannon index) and E (Shannon evenness index ) for each treatment. $\mathrm{H}$ was calculated as: $\mathrm{H}=-\Sigma(\mathrm{pi} * \ln \mathrm{pi})$. The variable pi is the proportion of species $\mathrm{i}$ in the plot (cover of species i) divided by the total plant cover in the plot and $\ln$ is the natural $\log$ function. E was calculated as: $E=H / \ln (S)$; $S$ is the number of species per plot. Then I calculated the average number of species per treatment. 
At each sampling period, three T. testudinum and 15 S. filiforme shoots were collected prior to clipping at each plot, placed in ice and transported to the laboratory. Morphological measurements of the leaves of T. testudinum (length and width) and $S$. filiforme (leaf length) were recorded. The epiphytes on the leaf material of each species was gently scraped off with a razor blade, and the leaves were dried at $70^{\circ} \mathrm{C}$, weighed, ground to a fine powder and analyzed for carbon $(\mathrm{C})$, nitrogen $(\mathrm{N})$ and phosphorus $(\mathrm{P})$. I did not collect $H$. wrightii shoots because their small size would require collecting so much material that the composition of the plots could be altered. For each species within each plot, seagrass leaf material was pooled. Since plant tissue stoichiometry can be used as an indicator of the fertility of the ecosystem (Atkinson and Smith 1983), the CNP data were used to interpret competitive interactions among the constituent species. Carbon and nitrogen content were determined using a CHN analyzer. Phosphorus content was determined by a dry-oxidation, acid hydrolysis extraction followed by colorimetric analysis (Fourqurean et al. 1992a). Elemental content and ratios were calculated on a dry weight and mole:mole basis, respectively.

\section{ANALYSIS}

The elemental content, absolute cover of the seagrasses and canopy height were tested using a repeated measures ANOVA (time $(\mathrm{T})$, nutrient $(\mathrm{F})$, grazing $(\mathrm{G})$ and nutrient x grazing) (Proc GLM in SAS 9.2). If necessary, data were log-transformed to achieve normality (Kolmogorov-Smirnoff test) and homogeneity of variances (Bartlett's test). A full factorial 2-way ANOVA was done to compare leaf elemental content, absolute cover of the seagrasses and canopy height at each sampling period (nutrient, 
grazing and nutrient $\mathrm{x}$ grazing). For factors with significant effects, I compared means using Tukey's test. The comparison was considered statistically significant at $\mathrm{p} \leq 0.05$. When there was significant interaction between the effects of nutrient addition and grazing, means of one factor were compared using Tukey's test separately at each level of the other factor and vice versa.

\section{RESULTS}

\section{Leaf nutrient content}

The elemental content of $T$. testudinum and $S$. filiforme significantly changed over time ( $\mathrm{p}<0.001$, time main effect, Table 3.1). The carbon, nitrogen and phosphorus content of T. testudinum and S. filiforme showed a marked seasonality (Figures 3.1, 3.2, 3.3, 3.4, 3.5, 3.6, 3.7, and 3.8, Table 3.2). $\mathrm{N}$ and $\mathrm{P}$ content of these two species were lower during the summer months driving the $\mathrm{C}: \mathrm{N}$ and $\mathrm{C}: \mathrm{P}$ ratio to increase. The effects of fertilization on the leaf $\mathrm{P}$ content of $T$. testudinum did not vary with time ( $\mathrm{T} \times \mathrm{F}$ interaction, $\mathrm{p}>0.05$, Table 3.1). The leaf $\mathrm{P}$ content of $T$. testudinum significantly increased after two years of fertilization (Figure $3.1 \mathrm{~b}, \mathrm{p}=0.015$, $\mathrm{T}$ x F interaction, Table 3.1) which caused a decrease in its C:P ratio (Figure 3.5b, Table 3.2). Leaf $\mathrm{N}$ content of $T$. testudinum did not respond to nutrient addition, but there was a significant decrease in its leaf C:N ratio (Figure 3.1a and 3.5a, Table 3.2), indicating a possible carbon limitation. There was greater effect of fertilization on T. testudinum leaf $\mathrm{P}$ content in the $2 \mathrm{~F}$ plots than in the $1 \mathrm{~F}$ plots. The leaf $\mathrm{P}$ content of T. testudinum significantly decreased in the grazed plots with time (Figure $3.2 \mathrm{~b}, \mathrm{p}<0.0001, \mathrm{~T} \times \mathrm{F}$ interaction, Table 3.1) causing a decrease in its $\mathrm{C}: \mathrm{P}$ ratio (Figure 3.6b, Table 3.2). The elemental content of T. testudinum did not respond to the interactive 
effects of fertilization and simulated grazing (Figure 3.3a, b, c, 3.4a, b, c, 3.7a, c, e and 3.8a, c, e, p>0.05, Table 3.1).

The effects of fertilization and grazing on the nutrient content of S. filiforme did not vary with time ( $>0.05, \mathrm{~T}$ x F interaction, $\mathrm{T} \mathrm{X} \mathrm{G}$ interaction, Table 3.1). Nutrient addition significantly increased the leaf N content of S. filiforme in May 2008 and January 2009 that caused an increased in the $\mathrm{C}: \mathrm{N}$ ratio (Figure 3.1c, 3.5c, Table 3.2). Leaf P content of S. filiforme increased while its C:P ratio significantly decreased in the enriched plots from May 2008 to July 2009 ( $<<0.001$, Figure 3.1d, 3.5d, Table 3.1, Table 3.2). There was a greater effect of nutrient addition on the $\mathrm{P}$ content of S. filiforme in the 2 F plots than in the 1F plots. Grazing increased the leaf N content of S. filiforme in April and July 2009 (Figure 3.2c, Table 3.2). The C:N ratio of S. filiforme significantly decreased in the grazed plots in January and April 2009 (Figure 3.6c, Table 3.2). The P content of S. filiforme decreased in the grazed plots causing an increase in the C:P ratio in July 2008 (Figures $3.2 \mathrm{~d}$ and 3.6d, Table 3.2). There was a greater increase in leaf $\mathrm{N}$ and $\mathrm{P}$ content of S. filiforme in fertilized plots that were not clipped in July 2008 (Figures 3.3d, $\mathrm{e}, \mathrm{f}$ and $3.4 \mathrm{~d}, \mathrm{e}, \mathrm{f}$, Table 3.2)

Absolute abundance of primary producers

There was no difference in absolute abundance of all primary producers across all treatments at the beginning of the experiment. There was a significant interaction between time and the effects of fertilization and simulated grazing on the absolute abundance of the primary producers $(\mathrm{p}<0.001$, Time main effect, Table 3.1$)$. The effects of fertilization on $T$. testudinum varied over time $(\mathrm{p}=0.015$, Figure $3.9 \mathrm{a}, \mathrm{T}$ x F interaction, 
Table 3.1). Fertilization across all clipping levels increased the absolute abundance of $T$. testudinum by an average of $15 \%$ and $43 \%$ in the $1 \mathrm{~F}$ and $2 \mathrm{~F}$ plots, respectively, from March to May 2008 (Figure 3.9a, Table 3.3) but T. testudinum stopped responding to fertilization in succeeding sampling periods.

Averaged across all clipping levels, fertilization significantly increased the absolute abundance of S. filiforme over time (Figure 3.9b, $\mathrm{p}<0.001$, T x F interaction, Table 3.3). The absolute abundance of S. filiforme increased by an average of $23 \%$ and $44 \%$ in the $1 \mathrm{~F}$ and $2 \mathrm{~F}$ plots, respectively, from July 2008 until July $2009(\mathrm{p}<0.001$, Figure 3.9b, Table 3.3). H. wrightii did not respond to fertilization until July 2009 in which its absolute abundance significantly decreased by $58 \%$ and $110 \%$ in the $1 \mathrm{~F}$ and $2 \mathrm{~F}$ plots, respectively (Figure 3.9c, Table 2). Fertilization increased the absolute abundance of Halimeda from May 2009 to July 2009 by an average of $36 \%$ and $65 \%$ in the 1F and 2F plots, respectively (Figure 3.9d, Table 3). The absolute abundance of Penicillus did not respond to fertilization (Figure 3.9e, Table 3.3). Simulated grazing across all levels of fertilization did not have any effect on the absolute abundance of $T$. testudinum, $H$. wrightii, Halimeda and Penicillus (Figure 3.11 a, b, c, f, g, h, 3.12a, b, c, d, e and f, Table 3.3). The absolute abundance of S. filiforme decreased by an average of $21 \%$ and $23 \%$ in the $1 \mathrm{~F}$ and $2 \mathrm{~F}$ plots, respectively, across all levels of fertilization from July 2008 until the end of the experiment (Figure 3.11b, d, and e, Table 3.3). The response of S. filiforme to fertilization varied with grazing regime (Table 3.4). Fertilization had a larger effect on the absolute abundance of S. filiforme in the unclipped plots (Figure 3.11c, d, and e, and Table 3.4). 
Number of Species and Species Evenness

There was a significant effect of time on number of species and evenness (E) across all levels of fertilization and simulated grazing (Time main effect, $\mathrm{p}<0.001$, Tables 3.1). Fertilization decreased number of species with time $(p=0.018$, Figure $13 a, T \times F$ interaction, Table 3.1) but species evenness in the fertilized plots did not vary with time (Figure 13b, Table 3.1). There was no significant interaction between time and the effects of simulated grazing and the interactive effects of fertilization and simulated grazing (T x G, T x F x G, p>0.05, Figure 3. 14, Table 3.1). There was no effect of fertilization and simulated grazing on the number of species and species evenness (Table 3.1). The effects of fertilization on the number of species were greater in the $0 \mathrm{G}$ and $1 \mathrm{G}$ plots ( $\mathrm{p}=0.014$, Figure 3. 15, Table 3.1).

\section{Canopy Height}

There was no significant difference in canopy height across all treatments at the beginning of the experiment. There was significant change in the seagrass canopy height across all fertilization and simulated grazing treatments over time ( $<<0.001$, Table 3.1$)$. The effects of fertilization and simulated grazing on the canopy height increased with time ( $\mathrm{p}<0.001$, T x F interaction, T x G interaction, Figure 3.16a and b, Table 3.1). Averaged across all clipping treatments, fertilization increased canopy height across all levels of grazing ( $p<0.001$, Figures 3.16a, table $3.1,3.5$ ) while simulated grazing decreased canopy height across all fertilization treatments from July 2008 to July 2009 (Figure 3.16b, Table 3.1 and 3.5). There were no interactive effects of grazing and fertilization on canopy height: grazing had the same relative effect on canopy height 
across all levels of fertility and fertilization had the same relative effects across all levels of grazing ( $>>0.05$, Figures 3.17, Table 3.1 and Table 3.5).

\section{DISCUSSION}

The results of the two-year enrichment and clipping experiment clearly show that fertilization and grazing are important drivers of seagrass community structure. Although there is a marked seasonality in the plant responses, the measured variables still showed distinct differences in the responses of the different species to the treatments. The lower $\mathrm{N}$ and $\mathrm{P}$ content of T. testudinum and S. filiforme in the summer months suggests a greater nutrient demand coinciding with reported high productivity during this period (Kerr and Strother 1989, Fourqurean et al. 2001, Enriquez et al. 2004) when there is high light availability (Dennison 1987, Abal et al. 1994). The pattern in absolute cover of the seagrass species across the experimental plots demonstrates clearly that species abundance can be influenced by the direct impacts of fertilization and grazing. It also appears that the negative impacts of grazing on the absolute abundance of seagrasses were mitigated by fertilization.

The effects of fertilization on plants in this study are consistent with those reported by other studies in which there was an overall increase in plant cover and canopy height in the fertilized plots (Feller 1995, Agawin et al. 1996, Udy et al. 1999, Armitage et al. 2005). The three seagrass species differed in their response to fertilization. The absolute abundance of T. testudinum increased after eight months of fertilization but stopped responding after 11 months. It took longer for $S$. filiforme to respond to fertilization. Fertilization increased the absolute abundance of S. filiforme 11 
months into the experiment, which corresponds to the period that $T$. testudinum stopped responding to the increase in nutrient supply. This suggests that S. filiforme became competitively dominant over that of $T$. testudinum, a species with a higher light requirement. Fertilization could increase nutrient availability over time which would favor fast growing speices with higher nutrient requirement. Experimental work in Florida Bay has demonstrated that phosphorus retention in the system could exceed $100 \%$ of the $\mathrm{P}$ added as fertilizer and remain in the system for decades (Herbert and Fourqurean 2008, Armitage et al. 2011). The increase in the leaf P content of $T$. testudinum two years into the experiment without an associated increase in abundance indicates that it was not utilizing the available $\mathrm{P}$ because of light limitation.

The increase in canopy height in the fertilized plots was largely due to the vertical rhizomes of S. filiforme that can extend above the sediment surface into the water column allowing it to form dense stands (Kenworthy and Schwarzschild 1998) and shade the other species. The smaller species, $H$. wrightii, decreased in abundance after two years, suggesting that it was outcompeted for light and space. In contrast, other long term fertilization studies in Florida Bay showed that $H$. wrightii outcompeted $T$, testudinum in the absence of S. filiforme (Fourqurean et al. 1995, Armitage et al. 2011). Burd and Dunton (2001) reported that light was a major factor controlling $H$. wrightii productivity. Light addition to the understory of a fertilized experimental grassland plant community maintained plant diversity (Hautier et al. 2009), thus providing evidence that competition for light is a major mechanism of species loss after eutrophication. So an unabated increase in nutrient enrichment could lead to low species diversity. 
The increase in the absolute abundance of the macroalgae Halimeda in the fertilized plots could be due to the reported capacity of Halimeda to take advantage of episodic nutrient supply and this species' low light requirement to reach the photosynthetic compensation point (Littler et al. 1988). Furthermore, the results of a study by Davis and Fourqurean (2001) suggest that Halimeda competes with seagrasses for nutrients more than for light. Penicillus was not affected by fertilization.

The absolute abundance of $S$. filiforme decreased in the clipped plots a year after the start of the experiment but there was no effect on T. testudinum, Halimeda and Penicillus. A simulated grazing study in Puerto Rico reported a similar lack of response to grazing by T. testudinum (Moran and Bjorndal 2005). The decrease in abundance of $S$. filiforme in the clipped plots corresponds with the decrease in its leaf $\mathrm{N}$ and $\mathrm{P}$. The delayed effect of simulated grazing on S. filiforme may be due to the two month interval between grazing events that gave the plants ample time to recover. Furthermore, seagrasses are capable of translocating resources between photosynthetic shoots along the rhizome (Terrados et al. 1997, Marba et al. 2002); unclipped plants in the plots can subsidize clipped plants. The decrease in the abundance of $S$. filiforme in the clipped plots may also be due to its lower carbon uptake rate $\left(1.74( \pm 0.26) \mathrm{CgDW}^{-1} \mathrm{~h}^{-1}\right)$ compared to H. wrightii $\left(2.33( \pm 0.28) \mathrm{CgDW}^{-1} \mathrm{~h}^{-1}\right)$ and T. testudinum $\left(2.02( \pm 0.12) \mathrm{CgDW}^{-1} \mathrm{~h}^{-1}\right)$ (Zieman et al. 1989). Carbon-limitation in S. filiforme was probably exacerbated by the loss of leaves due to clipping. This is evident in the reduced absolute growth rate of $S$. filiforme in the clipped plots (Chapter 2). The increase in the leaf $\mathrm{N}$ of S. filiforme in April 2009 in the clipped plots may have been due to its flowering (Chapter 4). It may 
have allocated more $\mathrm{N}$ to the leaves to meet the increased demands of sexual reproduction. Nutrients are allocated preferentially to areas of greatest meristematic activity as determined by growth stage (Chapin 1980).

Halodule wrightii, which decreased in abundance in the fertilized plots, was not affected in the grazed plots; this suggests that clipping of the larger species, T. testudinum and $S$. filiforme allowed the smaller species $H$. wrightii to persist. The decrease in the canopy height in the clipped plots allows more light to reach the smaller species. Simulated grazing had no significant effect on the absolute abundance of the $T$. testudinum, Halimeda and Penicillus. This result lends support to the prediction of the intermediate disturbance hypothesis model (Connell 1978, 1983) that removal of the dominant species would allow more species to coexist. An herbivore exclosure experiment in a heather moorland led to strong competition for light as the heather canopy closed (Alonso and Hartley 1998).

The decrease in the absolute abundance of S. filiforme in the plots that were both enriched and clipped suggest that $S$. filforme requires a high nutrient supply to recover from grazing and is not efficient in competing for nutrients with $T$. testudinum, a species that has an extensive rhizome system, and the fast growing $H$. wrightii. Williams (1987) reported that aboveground productivity of S. filiforme was limited by belowground competition for nutrients with T. testudinum. The decrease in the abundance of S. filforme allowed the smaller and fast growing species, $H$. wrightii to take advantage of the increase in nutrient supply and light availability.

The decrease in the number of species with time in the fertilized plots reflects the 
changes in the abundances of the primary producers. Fertilization could change the composition of a community (Grime 2001) by allowing plants that are adapted to acquire resources efficiently to dominate (Tilman 1990, Rajaniemi 2002). The results of most experiments in which production has been increased by enrichment of soil resources have shown a corresponding decline in species diversity (Goldberg and Miller 1990, Fridley 2002) and the mechanism generally presumed to cause the decrease in species richness is an increased intensity of competition at higher plant biomass (Grime 1979, Huston 1979, Tilman 1988, Huston 1994). A decrease in species diversity could negatively impact ecosystem functioning (reviewed in Schwartz et al., 2000, Cottingham et al., 2001, Loreau et al., 2001). The decrease in species diversity could also lead to a loss of structural diversity, which is an important component of the seagrass bed as a habitat, breeding area and nursery for marine organisms (Heck et al. 1995, Guidetti and Bussotti 2002). Thus, maintaining greater species diversity in a seagrass bed will increase its productivity and structural complexity as a habitat. The vertical growth habit of $S$. filiforme and T. testudinum can form tall, multilayered canopies, which influence local hydrodynamics, promote sedimentation, and provide refuge for marine organisms (Heck 1977, Kenworthy and Schwarzschild 1998, Koch 1999, van Keulen and Borowitzka 2002). Greater species diversity would also enhance the resilience and recovery of the community after a disturbance. A more diverse ecosystem containing species that respond differently to multiple stressors would make the ecosystem more stable (Loreau et al. 2003, Hooper et al. 2005).

In this study simulated grazing had no consistent effect on the number of species and species evenness across all fertilization treatments. At high simulated grazing rates, 
increased fertility allowed the species to coexist. Grazing prevented competitive exclusion through biomass removal of the dominant species (Lubchenco 1975, Proulx and Mazumder 1998). However, an intense grazing regime could also reduce productivity and structural complexity of a seagrass meadow. Although the effects of fertilization seem to alleviate the negative impacts of simulated grazing in this study, this might not be true under conditions where there are herbivores that would prefer to feed on plants with high nutrient content. Under these conditions, fertilization can then exacerbate or increased the relative impact of grazing. Grazing studies have shown enhanced grazing by herbivores on fertilized plants (McGlathery 1995, Silliman and Zieman 2001, Armitage and Fourqurean 2006). An increase in the diversity of the grazers could lead to differential grazing on the different species therefore allowing more species to coexist because not one species is decimated by the herbivores. In addition, primary productivity changes with plant community composition and is, therefore, strongly affected by plant species replacement due to herbivore preference (de Mazancourt and Loreau 2000).

Species-specific responses to treatments were in part predictable as a function of plant life form and nutrient requirement. The smaller, fast growing species $H$. wrightii was favored by the combined fertilization and clipping treatment. T. testudinum, which has a low nutrient requirement and extensive root and rhizome system, was not negatively affected by fertilization and grazing. The slow response of $T$. testudinum to environmental stress could be a result of its stored starch reserves in its extensive robust rhizome system (Zieman 1975) and the other species has to build up enough biomass to outcompete T. testudinum (Fourqurean et al. 1995). Syringodium filiforme, which can 
branch out and form a tall canopy, dominated in the fertilized plots but was not as competitive in the plots that were both grazed and enriched. Although the time frame of this experiment was not long enough to observe large shifts in the community structure, the species-specific responses to fertilization, simulated grazing and the interactive effects of fertilization and simulated grazing allowed us to predict the future trajectory of seagrass community composition. Changes in the community composition of the seagrass bed in response to increased nutrient supply will follow the trajectory predicted by the seagrass replacement model (Fourqurean et al. 2004). Simulated grazing prevented competitive exclusion in the fertilized plots by the removal of the dominant species. This provides support to our model (Chapter 1) that predicts that the interactive effects of fertilization and grazing would delay the trajectory predicted by Fourqurean's (2004) model.

Nutrient addition and simulated grazing both exerted strong control on plant performance in this seagrass bed. In addition, neither bottom up nor top down influences were eliminated in treatments where both factors were present. The effects of fertilization on plant performance were marked under all clipping intensities indicating that the system is regulated by nutrient availability both in the presence or absence of grazers. Clipping effects were strong under both fertilized and unfertilized conditions indicating that the seagrass bed can be simultaneously under top-down control by grazers. 
Table 3.1. Repeated measures analysis of variance of the effect of nutrient and simulated grazing on response variables measured for two years. Significant effects (defined as $p \leq$ $0.05)$ are designated in boldface type. Time $(\mathrm{T})$, Fertilization $(\mathrm{F})$, Simulated grazing $(\mathrm{G})$

\begin{tabular}{|c|c|c|c|}
\hline Variables & Source & $\mathrm{F}_{45,2}$ & $\mathrm{P}$ \\
\hline \multicolumn{4}{|l|}{ T. testudinum } \\
\hline \multicolumn{4}{|l|}{ Absolute abundance } \\
\hline \multirow{5}{*}{ Within subjects } & $\mathrm{T}$ & 9.34 & $<0.001$ \\
\hline & $\mathrm{T} \times \mathrm{F}$ & 2.1 & 0.015 \\
\hline & $\mathrm{T} \times \mathrm{G}$ & 1.55 & 0.1 \\
\hline & $\mathrm{T} \times \mathrm{F} \times \mathrm{G}$ & 1.28 & 0.15 \\
\hline & F & 1.2 & 0.31 \\
\hline \multirow{2}{*}{ Between subjects } & G & 0.25 & 0.77 \\
\hline & $\mathrm{F} \times \mathrm{G}$ & 0.58 & 0.68 \\
\hline \multicolumn{4}{|l|}{ Leaf $\mathrm{N}$ content } \\
\hline \multirow[t]{4}{*}{ Within subjects } & $\mathrm{T}$ & 40.45 & $<0.001$ \\
\hline & $\mathrm{T} \times \mathrm{F}$ & 0.42 & 0.97 \\
\hline & $\mathrm{T} \times \mathrm{G}$ & 1.32 & 0.24 \\
\hline & $T \times F \times G$ & 1.33 & 0.15 \\
\hline \multirow[t]{3}{*}{ Between subjects } & $\mathrm{F}$ & 1.96 & 0.16 \\
\hline & G & 0.23 & 0.79 \\
\hline & $F \times G$ & 1.05 & 0.4 \\
\hline \multicolumn{4}{|l|}{ Leaf $\mathrm{P}$ content } \\
\hline \multirow[t]{4}{*}{ Within subjects } & $\mathrm{T}$ & 28.89 & $<0.001$ \\
\hline & $\mathrm{T} \times \mathrm{F}$ & 1.35 & 0.23 \\
\hline & $\mathrm{T} \times \mathrm{G}$ & 2.38 & 0.017 \\
\hline & $T \times F \times G$ & 0.89 & 0.64 \\
\hline \multirow[t]{3}{*}{ Between subjects } & $\mathrm{F}$ & 1.32 & 0.29 \\
\hline & G & 1.24 & 0.31 \\
\hline & $F \times G$ & 0.64 & 0.64 \\
\hline \multicolumn{4}{|l|}{ Leaf $\mathrm{CN}$ ratio } \\
\hline \multirow[t]{4}{*}{ Within subjects } & $\mathrm{T}$ & 42.37 & $<0.001$ \\
\hline & $\mathrm{T} \times \mathrm{F}$ & 0.47 & 0.94 \\
\hline & $\mathrm{T} \times \mathrm{G}$ & 1.04 & 0.44 \\
\hline & $T \times F \times G$ & 1.37 & 0.14 \\
\hline \multirow{3}{*}{ Between subjects } & $\mathrm{F}$ & 3.01 & $<0.001$ \\
\hline & G & 0.51 & 0.61 \\
\hline & $\mathrm{F} \times \mathrm{G}$ & 1.42 & 0.26 \\
\hline
\end{tabular}




\begin{tabular}{|c|c|c|c|}
\hline \multicolumn{4}{|l|}{ Leaf CP ratio } \\
\hline \multirow[t]{4}{*}{ Within subjects } & $\mathrm{T}$ & 77.39 & $<0.001$ \\
\hline & $\mathrm{T} \times \mathrm{F}$ & 1.4 & 0.19 \\
\hline & $\mathrm{T} \times \mathrm{G}$ & 1.53 & 0.14 \\
\hline & $\mathrm{T} \times \mathrm{F} \times \mathrm{G}$ & 0.85 & 0.69 \\
\hline \multirow[t]{3}{*}{ Between subjects } & $\mathrm{F}$ & 1.66 & 0.21 \\
\hline & $\mathrm{G}$ & 1.3 & 0.29 \\
\hline & $\mathrm{Fx} \mathrm{G}$ & 0.44 & 0.78 \\
\hline \multicolumn{4}{|l|}{ S. filiforme } \\
\hline \multicolumn{4}{|c|}{ Absolute abundance } \\
\hline \multirow[t]{4}{*}{ Within subjects } & $\mathrm{T}$ & 26.42 & $<0.001$ \\
\hline & $\mathrm{T} \times \mathrm{F}$ & 2.89 & $<0.001$ \\
\hline & $\mathrm{T} \times \mathrm{G}$ & 1.25 & 0.25 \\
\hline & $T \times F \times G$ & 1.01 & 0.47 \\
\hline \multirow[t]{3}{*}{ Between subjects } & $\mathrm{F}$ & 10.12 & $<0.001$ \\
\hline & G & 6.18 & 0.005 \\
\hline & $\mathrm{F} \times \mathrm{G}$ & 2.33 & 0.075 \\
\hline \multicolumn{4}{|l|}{ Leaf $\mathrm{N}$ content } \\
\hline \multirow[t]{4}{*}{ Within subjects } & $\mathrm{T}$ & 46.94 & $<0.001$ \\
\hline & $\mathrm{T} \times \mathrm{F}$ & 1.23 & 0.29 \\
\hline & $\mathrm{T} \times \mathrm{G}$ & 1.56 & 0.13 \\
\hline & $T \times F \times G$ & 0.47 & 0.99 \\
\hline \multirow[t]{3}{*}{ Between subjects } & $\mathrm{F}$ & 5.07 & 0.015 \\
\hline & $\mathrm{G}$ & 0.34 & 0.72 \\
\hline & $\mathrm{F} \times \mathrm{G}$ & 0.35 & 0.84 \\
\hline \multicolumn{4}{|l|}{ Leaf $P$ content } \\
\hline \multirow[t]{4}{*}{ Within subjects } & $\mathrm{T}$ & 20.67 & $<0.001$ \\
\hline & $\mathrm{T} \times \mathrm{F}$ & 1.12 & 0.38 \\
\hline & $\mathrm{T} \times \mathrm{G}$ & 1.54 & 0.14 \\
\hline & $T \times F \times G$ & 0.76 & 0.81 \\
\hline \multirow[t]{3}{*}{ Between subjects } & $\mathrm{F}$ & 17.71 & $<0.001$ \\
\hline & $\mathrm{G}$ & 0.09 & 0.92 \\
\hline & $F \times G$ & 0.89 & 0.49 \\
\hline \multicolumn{4}{|l|}{ Leaf CN ratio } \\
\hline \multirow[t]{4}{*}{ Within subjects } & $\mathrm{T}$ & 39.19 & $<0.001$ \\
\hline & $\mathrm{T} \times \mathrm{F}$ & 1.56 & 0.13 \\
\hline & $\mathrm{T} \times \mathrm{G}$ & 1.24 & 0.29 \\
\hline & $\mathrm{T} \times \mathrm{F} \times \mathrm{G}$ & 0.75 & 0.82 \\
\hline \multirow[t]{3}{*}{ Between subjects } & $\mathrm{F}$ & 9.35 & $<0.001$ \\
\hline & $\mathrm{G}$ & 3.05 & 0.06 \\
\hline & $\mathrm{F} \times \mathrm{G}$ & 0.15 & 0.96 \\
\hline
\end{tabular}




\begin{tabular}{|c|c|c|c|}
\hline \multicolumn{3}{|l|}{ Leaf CP ratio } & $<0.001$ \\
\hline \multirow{6}{*}{ Between subjects } & $\mathrm{T} \times \mathrm{F}$ & 1.19 & 0.32 \\
\hline & $\mathrm{T} \times \mathrm{G}$ & 0.62 & 0.84 \\
\hline & $T \times F \times G$ & 0.63 & 0.93 \\
\hline & $\mathrm{F}$ & 26.37 & $<0.001$ \\
\hline & $\mathrm{G}$ & 0.89 & 0.43 \\
\hline & $\mathrm{F} \times \mathrm{G}$ & 0.52 & 0.72 \\
\hline \multicolumn{4}{|l|}{ H. wrightii } \\
\hline \multicolumn{4}{|l|}{ Absolute abundance } \\
\hline \multirow[t]{4}{*}{ Within subjects } & $\mathrm{T}$ & 2.57 & 0.009 \\
\hline & $\mathrm{T} \times \mathrm{F}$ & 1.76 & 0.079 \\
\hline & $\mathrm{T} \times \mathrm{G}$ & 0.67 & 0.76 \\
\hline & $\mathrm{T} \times \mathrm{F} \times \mathrm{G}$ & 0.67 & 0.76 \\
\hline \multirow[t]{3}{*}{ Between subjects } & $\mathrm{F}$ & 0.17 & 0.69 \\
\hline & $\mathrm{G}$ & 0.17 & 0.69 \\
\hline & $\mathrm{F} \times \mathrm{G}$ & 0.29 & 0.61 \\
\hline \multicolumn{4}{|l|}{ Halimeda } \\
\hline \multicolumn{4}{|l|}{ Absolute abundance } \\
\hline \multirow[t]{5}{*}{ Within subjects } & $\mathrm{T}$ & 5.96 & 0.006 \\
\hline & $\mathrm{T} \times \mathrm{F}$ & 1.29 & 0.28 \\
\hline & $\mathrm{T} \times \mathrm{G}$ & 1 & 0.49 \\
\hline & $\mathrm{T} \times \mathrm{F} \times \mathrm{G}$ & 0.87 & 0.67 \\
\hline & $\mathrm{F}$ & 0.29 & 0.75 \\
\hline \multirow[t]{2}{*}{ Between subjects } & $\mathrm{G}$ & 7.22 & 0.005 \\
\hline & $\mathrm{Fx} \mathrm{G}$ & 2.72 & 0.06 \\
\hline \multicolumn{4}{|l|}{ Penicillus } \\
\hline \multicolumn{4}{|l|}{ Absolute abundance } \\
\hline \multirow[t]{4}{*}{ Within subjects } & $\mathrm{T}$ & 3.02 & 0.015 \\
\hline & $\mathrm{T} \times \mathrm{F}$ & 1.05 & 0.44 \\
\hline & $\mathrm{T} \times \mathrm{G}$ & 0.62 & 0.64 \\
\hline & $\mathrm{T} \times \mathrm{F} \times \mathrm{G}$ & 1.21 & 0.64 \\
\hline \multirow[t]{3}{*}{ Between subjects } & $\mathrm{F}$ & 4.9 & 0.014 \\
\hline & G & 0.06 & 0.94 \\
\hline & $\mathrm{Fx} \mathrm{G}$ & 0.36 & 0.84 \\
\hline \multicolumn{4}{|l|}{ Number of species } \\
\hline \multirow[t]{4}{*}{ Within subjects } & $\mathrm{T}$ & 6.25 & $<0.001$ \\
\hline & $\mathrm{T} \times \mathrm{F}$ & 2.04 & 0.018 \\
\hline & $\mathrm{T} \times \mathrm{G}$ & 1.22 & 0.28 \\
\hline & $\mathrm{T} \times \mathrm{F} \times \mathrm{G}$ & 1.01 & 0.46 \\
\hline Between subjects & $\mathrm{F}$ & 1.15 & .045 \\
\hline
\end{tabular}




\begin{tabular}{llcc}
\hline & G & 0.89 & .53 \\
& F x G & $\mathbf{5 . 1 1}$ & $\mathbf{0 . 0 1 4}$ \\
\hline E & & & \\
Within subjects & T & $\mathbf{6 . 1 6}$ & $<\mathbf{0 . 0 0 1}$ \\
& T x F & $\mathbf{1 . 6 6}$ & $\mathbf{0 . 0 1 8}$ \\
& T x G & 1.05 & 0.39 \\
Between subjects & T x F x G & $\mathbf{1 . 5 2}$ & $\mathbf{0 . 0 2 2}$ \\
& F & 2.41 & 0.11 \\
& G & 1.60 & 0.21 \\
Canopy height & F x G & 0.66 & 0.62 \\
Within subjects & & & \\
& T & $\mathbf{4 4 . 1 6}$ & $<\mathbf{0 . 0 0 1}$ \\
& T x F & $\mathbf{3 . 0 5}$ & $<\mathbf{0 . 0 0 1}$ \\
& T x G & $\mathbf{3 . 2 3}$ & $<\mathbf{0 . 0 0 1}$ \\
Between subjects & T x F x G & 1.16 & 0.26 \\
& F & $\mathbf{4 9 . 2 4}$ & $<\mathbf{0 . 0 0 1}$ \\
& G & $\mathbf{1 5 . 2 5}$ & $<\mathbf{0 . 0 0 1}$ \\
& F x G & 0.48 & 0.75 \\
\hline
\end{tabular}


Table 3.2. ANOVA results of effects of nutrients and grazing on the absolute abundance of primary producers measured during the 24-month fertilization and grazing experiment. Significant effects (defined as $\mathrm{p} \leq 0.05$ ) are designated in boldface type.

\begin{tabular}{|c|c|c|c|c|c|c|}
\hline \multirow[t]{2}{*}{ Response variables } & \multicolumn{2}{|c|}{ Nutrient (F) } & \multicolumn{2}{|c|}{ Grazing (F) } & \multicolumn{2}{|c|}{ F $\times G$} \\
\hline & $\mathbf{F}_{45,2}$ & $\mathbf{P}$ & $\mathbf{F}_{45,2}$ & $\mathbf{P}$ & $\mathbf{F}_{45,4}$ & $\mathbf{p}$ \\
\hline \multicolumn{7}{|l|}{$\begin{array}{l}\text { Mar-08 } \\
\text { Absolute abundance }\end{array}$} \\
\hline T. testudinum & 8.45 & 0.001 & 2.59 & 0.09 & 0.44 & 0.78 \\
\hline S. filiforme & 0.4 & 0.67 & 0.64 & 0.53 & 1.26 & 0.31 \\
\hline H. wrightii & 3.72 & 0.07 & 0.09 & 0.91 & 0.49 & 0.63 \\
\hline Halimeda & 4.56 & 0.018 & 0.23 & 0.79 & 1.07 & 0.39 \\
\hline Penicillus & 0.97 & 0.39 & 0.77 & 0.47 & 0.9 & 0.47 \\
\hline \multicolumn{7}{|l|}{$\begin{array}{l}\text { 0May-08 } \\
\text { Absolute abundance }\end{array}$} \\
\hline T. testudinum & 4.58 & 0.017 & 0.14 & 0.87 & 0.24 & 0.91 \\
\hline S. filiforme & 3.14 & 0.15 & 2.02 & 0.15 & 1.46 & 0.23 \\
\hline H. wrightii & 0.88 & 0.44 & 0.94 & 0.49 & 0.89 & 0.44 \\
\hline Halimeda & 3.75 & 0.34 & 1.89 & 0.16 & 0.35 & 0.84 \\
\hline Penicillus & 0.44 & 0.07 & 0.53 & 0.59 & 0.01 & 1.00 \\
\hline \multicolumn{7}{|l|}{$\begin{array}{l}\text { Jul-08 } \\
\text { Absolute abundance }\end{array}$} \\
\hline T. testudinum & 1.59 & 0.22 & 0.4 & 0.22 & 0.31 & 0.87 \\
\hline S. filiforme & 7.18 & 0.002 & 4.06 & 0.026 & 1.58 & 0.2 \\
\hline H. wrightii & 1.31 & 0.29 & 2.77 & 0.13 & 3.74 & 0.04 \\
\hline Halimeda & 0.69 & 0.51 & 0.12 & 0.88 & 0.49 & 0.74 \\
\hline Penicillus & 1.6 & 0.22 & 1.6 & 0.22 & 0.8 & 0.53 \\
\hline \multicolumn{7}{|l|}{$\begin{array}{l}\text { Sep-08 } \\
\text { Absolute abundance }\end{array}$} \\
\hline T. testudinum & 1.62 & 0.21 & 0.23 & 0.79 & 1.15 & 0.35 \\
\hline S. filiforme & 6.88 & 0.003 & 3.35 & 0.046 & 1.24 & 0.31 \\
\hline H. wrightii & 0.47 & 0.63 & 0.39 & 0.68 & 0.78 & 0.52 \\
\hline Halimeda & 0.38 & 0.69 & 2.13 & 0.13 & 2.26 & 0.08 \\
\hline Penicillus & 2.47 & 0.09 & 0.47 & 0.63 & 0.33 & 0.85 \\
\hline \multicolumn{7}{|l|}{$\begin{array}{l}\text { Nov-08 } \\
\text { Absolute abundance }\end{array}$} \\
\hline T. testudinum & 0.05 & 0.95 & 0.84 & 0.43 & 0.76 & 0.56 \\
\hline S. filiforme & 20.22 & $<0.001$ & 10.67 & $<0.001$ & 1.56 & 0.21 \\
\hline H. wrightii & 0.97 & 0.39 & 0.19 & 0.82 & 0.51 & 0.68 \\
\hline Halimeda & 2.81 & 0.07 & 0.56 & 0.58 & 1.63 & 0.19 \\
\hline Penicillus & 0.06 & 0.94 & 2.31 & 0.12 & 0.28 & 0.89 \\
\hline
\end{tabular}




\begin{tabular}{|c|c|c|c|c|c|c|}
\hline \multicolumn{7}{|c|}{$\begin{array}{l}\text { Jan-09 } \\
\text { Absolute abundance }\end{array}$} \\
\hline T. testudinum & 1.54 & 0.23 & 0.52 & 0.6 & 0.77 & 0.55 \\
\hline S. filiforme & 10.75 & $<0.001$ & 5.25 & 0.01 & 2.88 & 0.036 \\
\hline H. wrightii & 2.56 & 0.11 & 1.15 & 0.34 & 0.47 & 0.71 \\
\hline Halimeda & 2.67 & 0.08 & 0.1 & 0.9 & 0.88 & 0.49 \\
\hline Penicillus & 4.01 & 0.027 & 3.51 & 0.04 & 0.49 & 0.75 \\
\hline \multicolumn{7}{|c|}{$\begin{array}{l}\text { Apr-09 } \\
\text { Absolute abundance }\end{array}$} \\
\hline T. testudinum & 0.78 & 0.47 & 0.05 & 0.95 & 0.63 & 0.64 \\
\hline S. filiforme & 9.59 & $<0.001$ & 5.03 & 0.012 & 1.1 & 0.37 \\
\hline H. wrightii & 1.01 & 0.38 & 0.48 & 0.62 & 0.61 & 0.62 \\
\hline Halimeda & 2.6 & 0.09 & 0.25 & 0.78 & 1.52 & 0.22 \\
\hline Penicillus & 3.11 & 0.06 & 0.11 & 0.89 & 1.09 & 0.37 \\
\hline \multicolumn{7}{|c|}{$\begin{array}{l}\text { May-09 } \\
\text { Absolute abundance }\end{array}$} \\
\hline T. testudinum & 1.92 & 0.16 & 0.16 & 0.85 & 1.15 & 0.35 \\
\hline S. filiforme & 39.47 & $<0.001$ & 6.67 & 0.003 & 3.67 & 0.013 \\
\hline H. wrightii & 2.30 & 0.13 & 0.05 & 0.95 & 0.65 & 0.63 \\
\hline Halimeda & 5.55 & 0.008 & 1.03 & 0.37 & 3.25 & 0.02 \\
\hline Penicillus & 5.3 & 0.01 & 0.17 & 0.85 & 0.39 & 0.81 \\
\hline \multicolumn{7}{|c|}{$\begin{array}{l}\text { Jul-09 } \\
\text { Absolute abundance }\end{array}$} \\
\hline T. testudinum & 1.08 & 0.35 & 1.08 & 0.35 & 0.46 & 0.77 \\
\hline S. filiforme & 20.67 & $<0.001$ & 12.67 & $<0.001$ & 3.01 & 0.03 \\
\hline H. wrightii & 5.36 & 0.016 & 0.88 & 0.43 & 0.65 & 0.63 \\
\hline Halimeda & 8.66 & 0.001 & 0.01 & 0.99 & 2.15 & 0.09 \\
\hline Penicillus & 0.73 & 0.49 & 0.41 & 0.67 & 0.61 & 0.66 \\
\hline
\end{tabular}


Table 3.3. ANOVA results on the effects of grazing on the absolute cover of S. filiforme at different fertilization regimes. Significant effects (defined as $p \leq 0.05$ ) are designated in boldface type.

\begin{tabular}{lcccccc}
\hline Time & \multicolumn{2}{c}{ OF } & \multicolumn{2}{c}{$1 \mathrm{~F}$} & \multicolumn{2}{c}{$2 \mathrm{~F}$} \\
& $\mathrm{~F}_{15,2}$ & $\mathrm{P}$ & $\mathrm{F}_{15,2}$ & $\mathrm{P}$ & $\mathrm{F}_{15,2}$ & $\mathrm{P}$ \\
\hline Jul-08 & 2.8 & 0.1 & $\mathbf{5 . 7}$ & $\mathbf{0 . 0 2 6}$ & 0.12 & 0.89 \\
Sep-08 & 0.29 & 0.76 & $\mathbf{4 . 7 7}$ & $\mathbf{0 . 0 3}$ & 0.14 & 0.87 \\
Nov-08 & 0.4 & 0.68 & $\mathbf{1 7 . 2}$ & $\mathbf{< . 0 0 1}$ & 4.57 & 0.03 \\
Jan-09 & 0.6 & 0.56 & $\mathbf{1 1 . 2}$ & $\mathbf{0 . 0 0 2}$ & 2.89 & 0.09 \\
Apr-09 & 0.22 & 0.80 & $\mathbf{5 . 5 6}$ & $\mathbf{0 . 0 2}$ & 1.64 & 0.24 \\
May-09 & 3.43 & 0.07 & $\mathbf{3 . 3 8}$ & $\mathbf{0 . 0 7}$ & 8.86 & 0.004 \\
Jul-09 & 4.8 & 0.029 & $\mathbf{7 . 9 1}$ & $\mathbf{0 . 0 0 6}$ & 3.46 & 0.06 \\
\hline
\end{tabular}

Table 3.4 . ANOVA results of effects of nutrients and grazing on canopy height measured during the 24 month fertilization and grazing experiment. Significant effects (defined as $p \leq 0.05$ ) are designated in boldface type.

\begin{tabular}{|c|c|c|c|c|c|c|}
\hline \multirow{2}{*}{$\begin{array}{l}\text { Canopy } \\
\text { Height }\end{array}$} & \multicolumn{2}{|c|}{ Nutrient (F) } & \multicolumn{2}{|c|}{ Grazing (G) } & \multicolumn{2}{|c|}{$\mathrm{F} \times \mathrm{G}$} \\
\hline & $\mathrm{F}_{45,2}$ & $\mathrm{P}$ & $\mathrm{F}_{45,2}$ & $\mathrm{P}$ & $\mathrm{F}_{45,4}$ & $\mathrm{P}$ \\
\hline Jul-08 & 5.76 & 0.007 & 5.39 & 0.009 & 1.78 & 0.15 \\
\hline Sep-08 & 25.31 & $<0.001$ & 8.88 & 0.001 & 0.54 & 0.70 \\
\hline Nov-08 & 28.09 & $<0.001$ & 9.91 & $<0.001$ & 0.67 & 0.62 \\
\hline Jan-09 & 35.34 & $<0.001$ & 16.81 & $<0.001$ & 0.08 & 0.98 \\
\hline Apr-09 & 35.89 & $<0.001$ & 14.13 & $<0.001$ & 0.10 & 0.98 \\
\hline May-09 & 39.27 & $<0.001$ & 14.83 & $<0.001$ & 0.14 & 0.97 \\
\hline Jul-09 & 65.56 & $<0.001$ & 29.08 & $<0.001$ & 0.72 & 0.59 \\
\hline
\end{tabular}



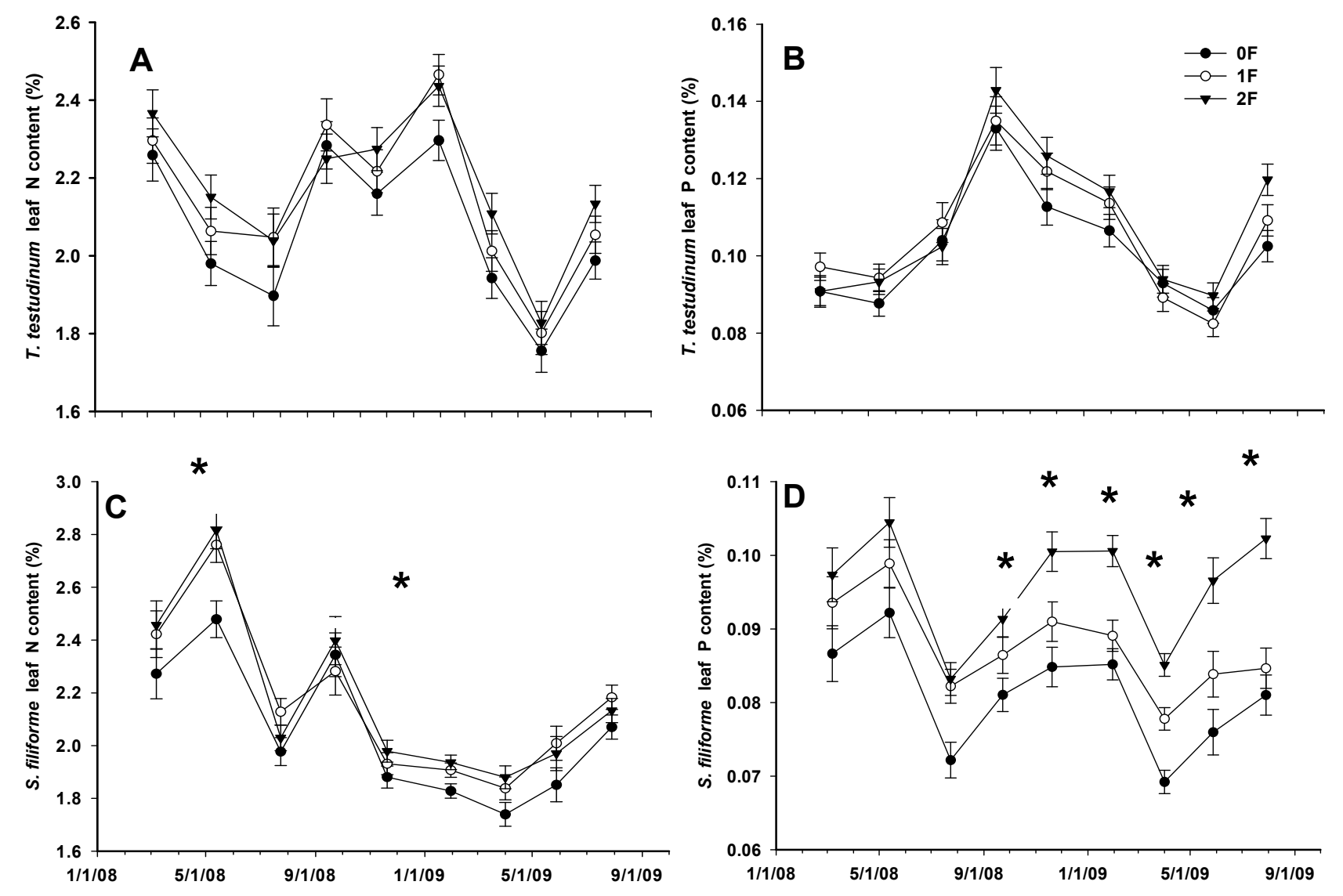

Figure 3.1. The effects of fertilization on (A) T. testudinum leaf N, (B) T. testudinum leaf P, (C) S. filiforme leaf N and (D) S. filiforme leaf P content as a percent of dry weight (means \pm standard error). Asterisks indicate significant difference among treatments. ( $<<0.05$, Tukey's HSD test) 

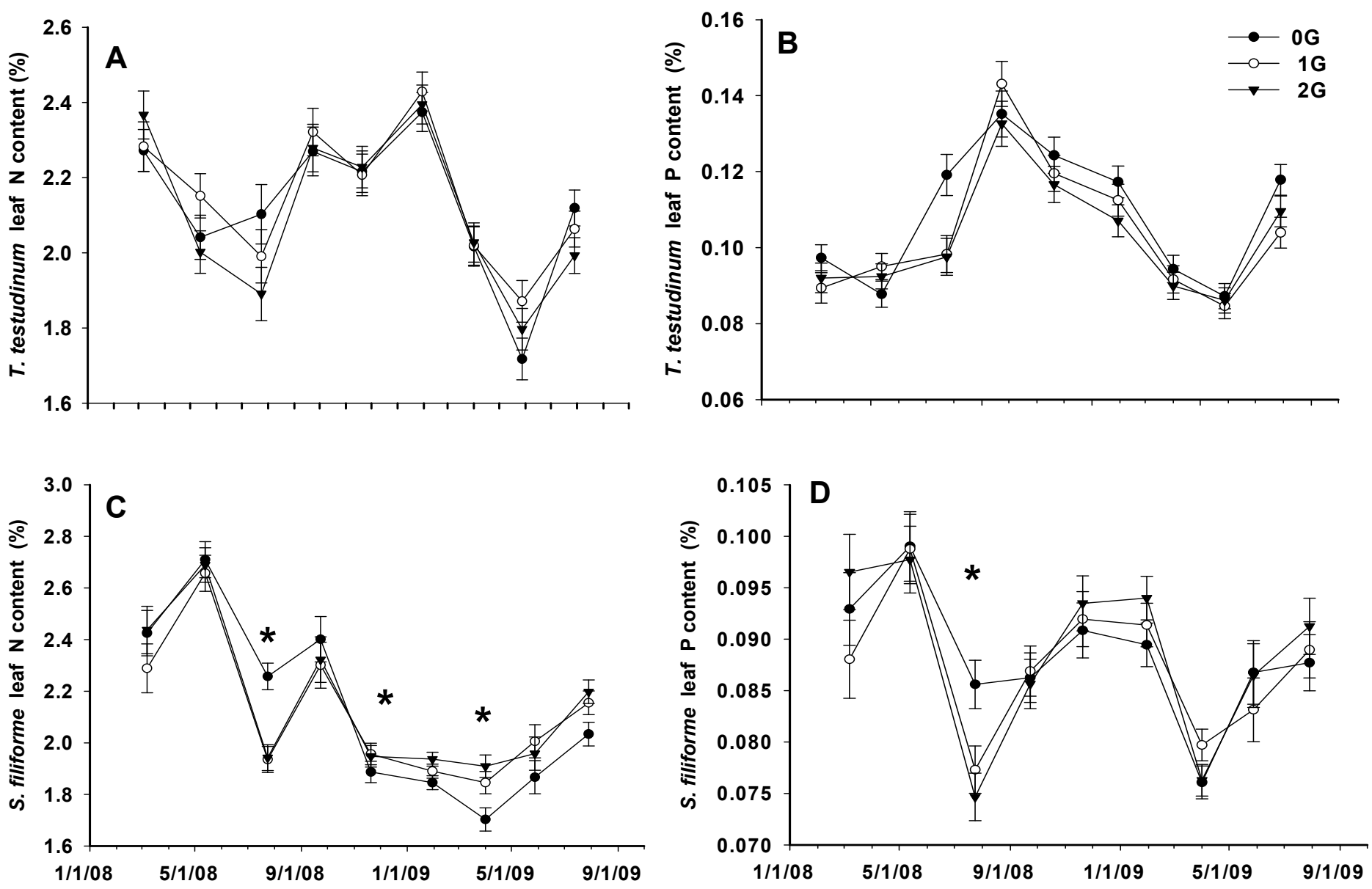

Figure 3.2. The effects of simulated grazing on (A) T. testudinum leaf N, (B) T. testudinum leaf $\mathrm{P}$, (C) S. filiforme leaf N and (Dd) S. filiforme leaf $\mathrm{P}$ content as a percent of dry weight (means \pm standard error). Asterisks indicate significant difference among treatments. ( $p<0.05$, Tukey's HSD test) 


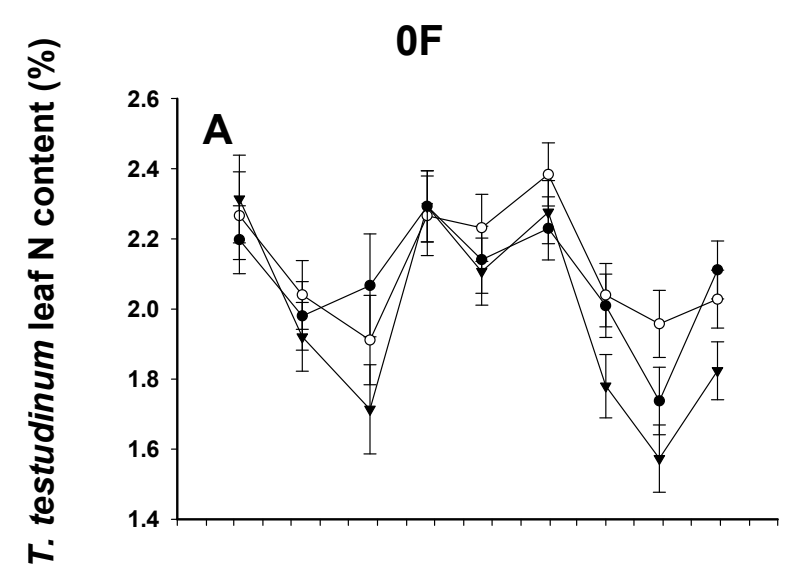

1F
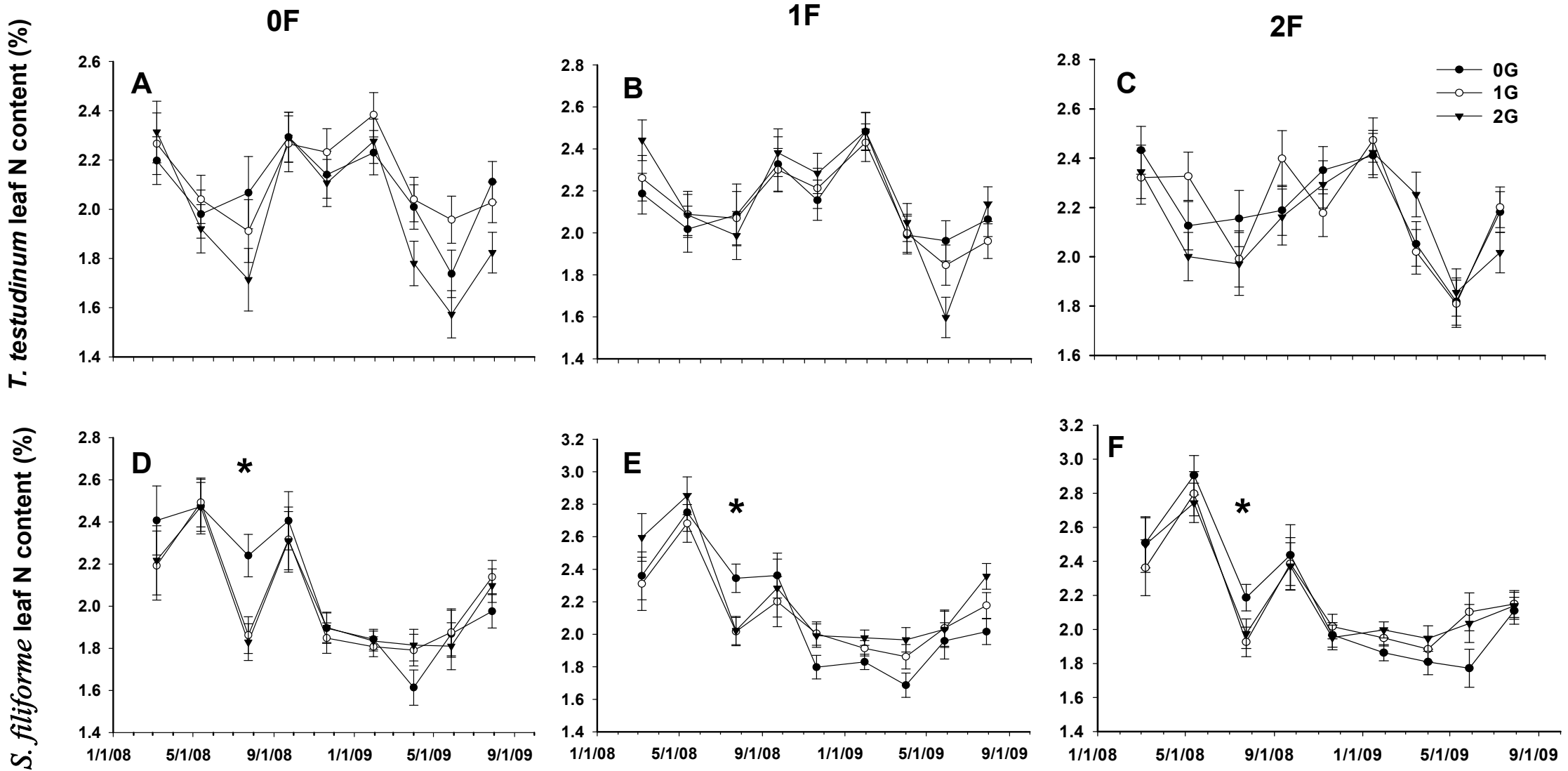

Figure 3.3. The interactive effects of fertilization and grazing on (A,B,C) T. testudinum leaf N, and (D,E,F) S. filiforme leaf N content as a percent of dry weight (means \pm standard error). Asterisks indicate significant difference among treatments. ( $<<0.05$, Tukey's HSD test) 


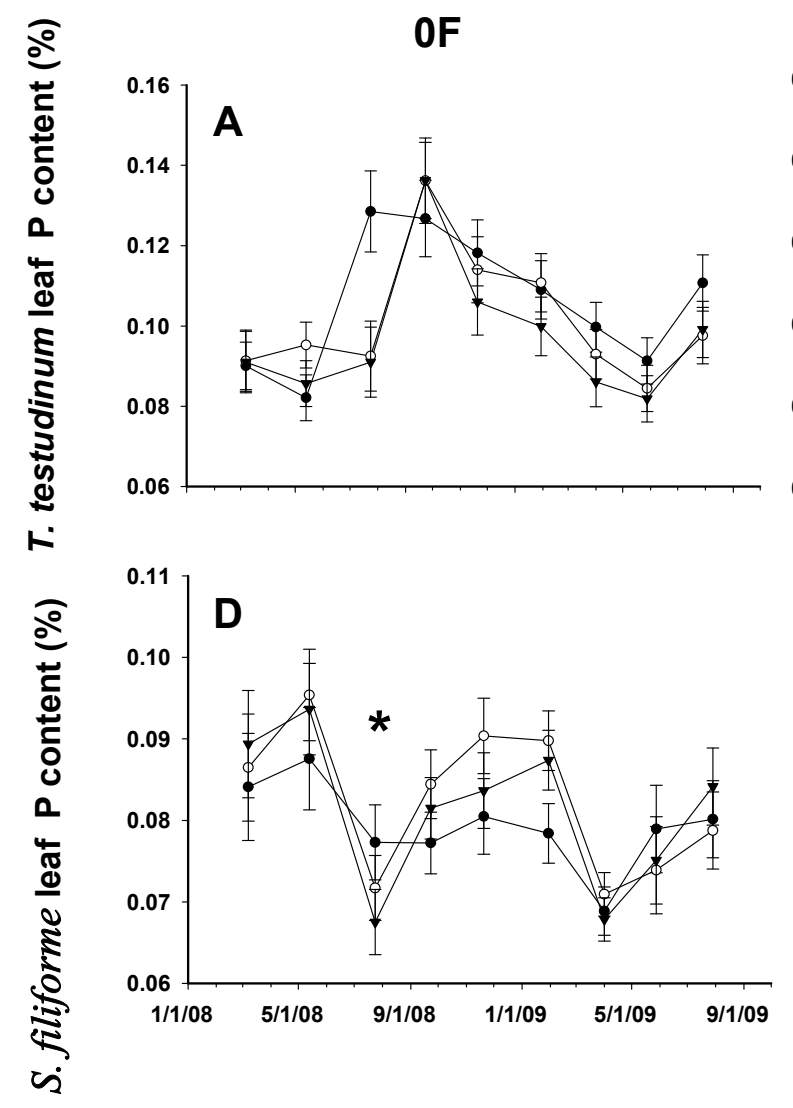

$1 F$
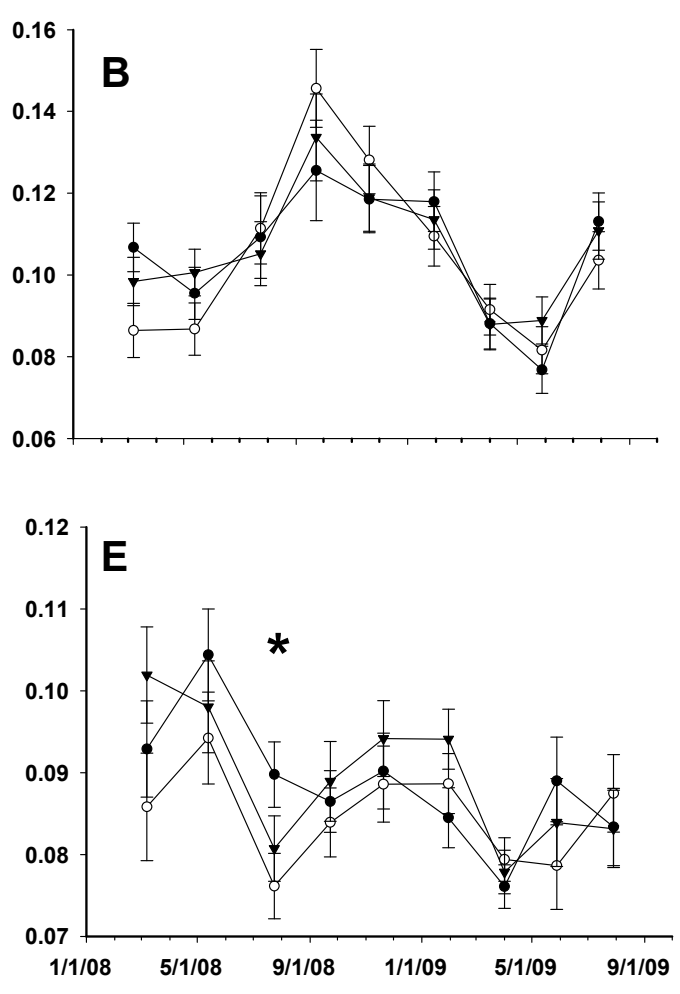

2F
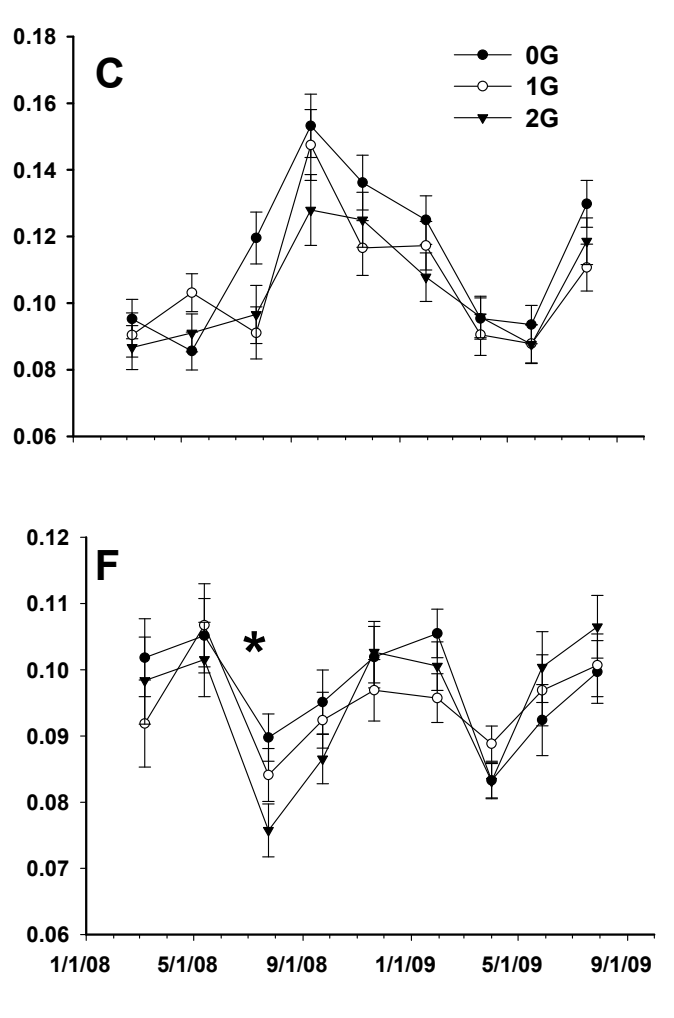

Figure 3.4. The interactive effects of fertilization and simulated grazing on (A,B,C) T. testudinum leaf $\mathrm{P}$, and (D,E,F) S. filiforme leaf $\mathrm{P}$ content as a percent of dry weight (means \pm standard error). Asterisks indicate significant difference among treatments. ( $<<0.05$, Tukey's HSD test) 

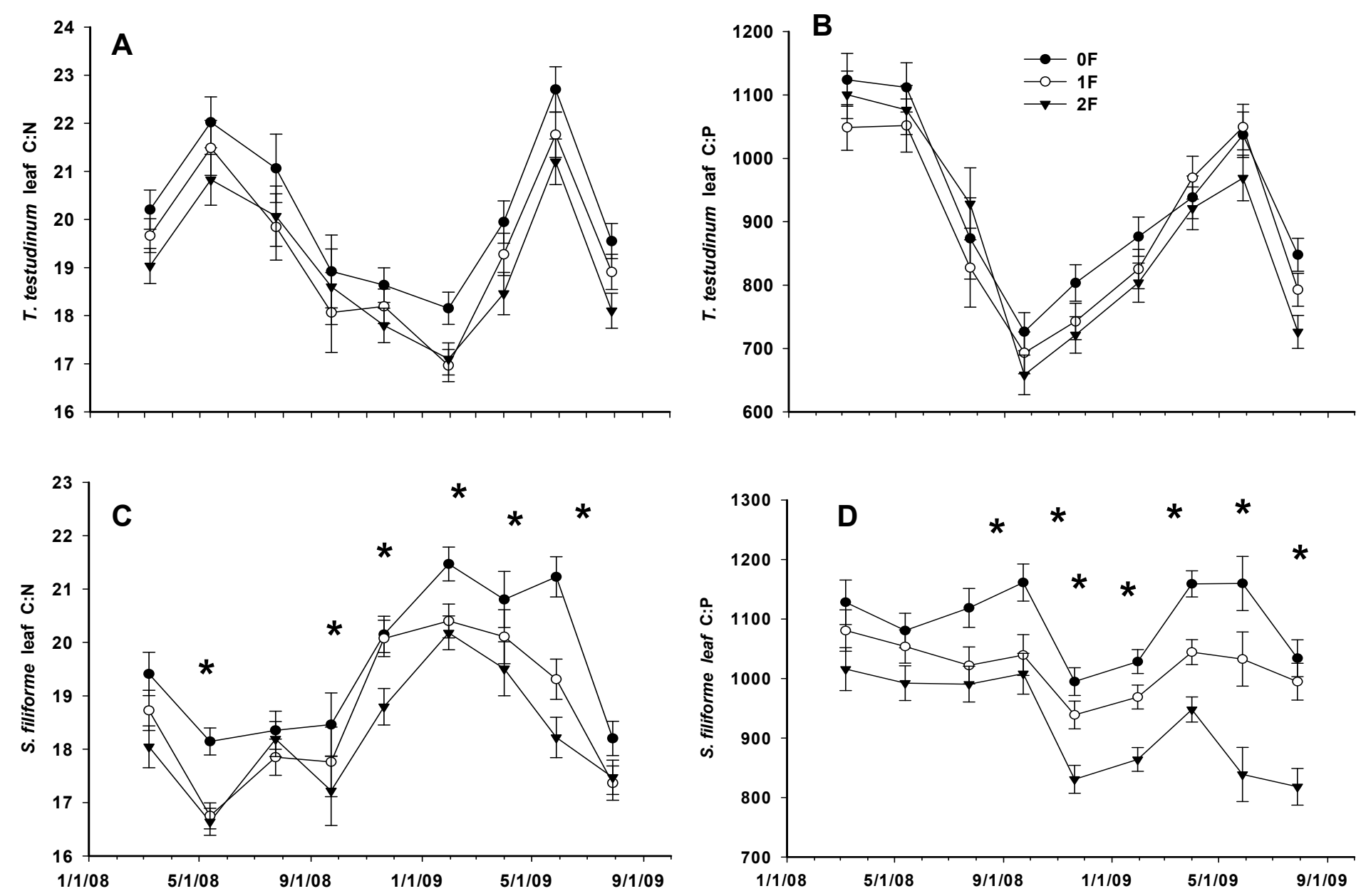

Figure 3.5. The effects of fertilization on (A) T. testudinum leaf C:N ratio, (A) T. testudinum leaf C:P ratio, (C) S. filiforme leaf C:N ratio and (D) S. filiforme leaf C:P ratio (means \pm standard error). Asterisks indicate significant difference among treatments. $(\mathrm{p}<0.05$, Tukey's HSD test) 

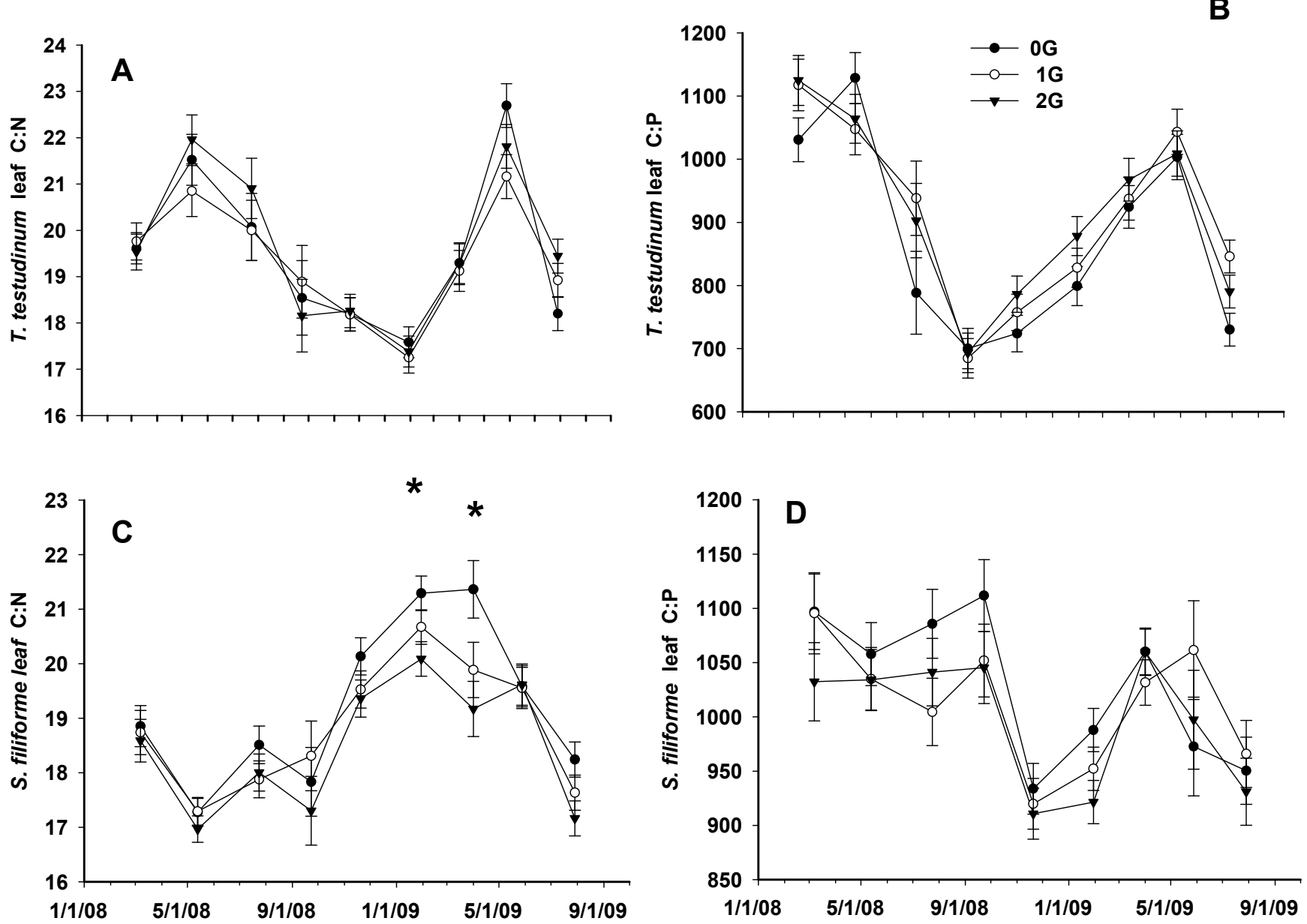

Figure 3.6. The effects of simulated grazing on (A) T. testudinum leaf C:N ratio, (B) T. testudinum leaf C:P ratio, (C) S. filiforme leaf C:N ratio and (D) S. filiforme leaf C:P ratio (means \pm standard error). Asterisks indicate significant difference among treatments. ( $<<0.05$, Tukey's HSD test) 


\section{T. testudinum leaf C:N}
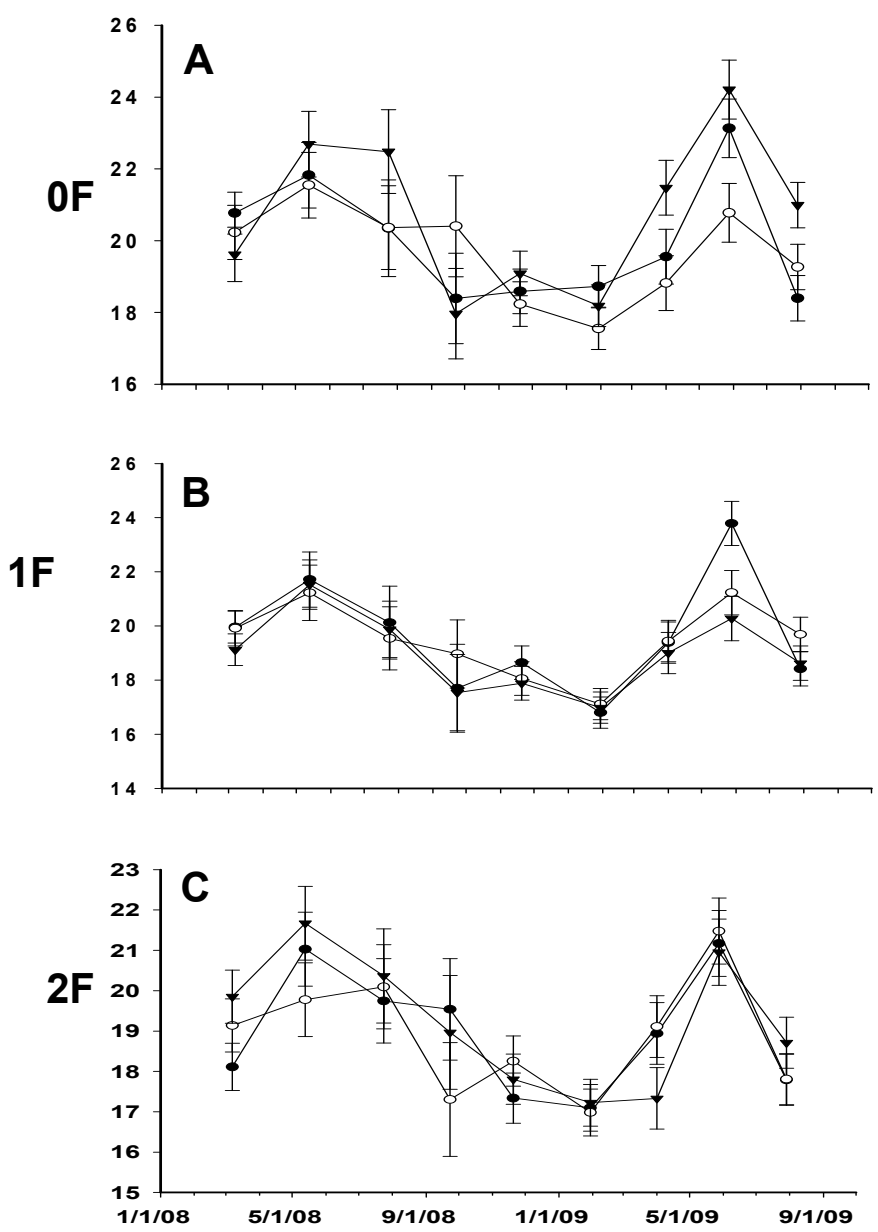

\section{S. filiforme leaf C:N}
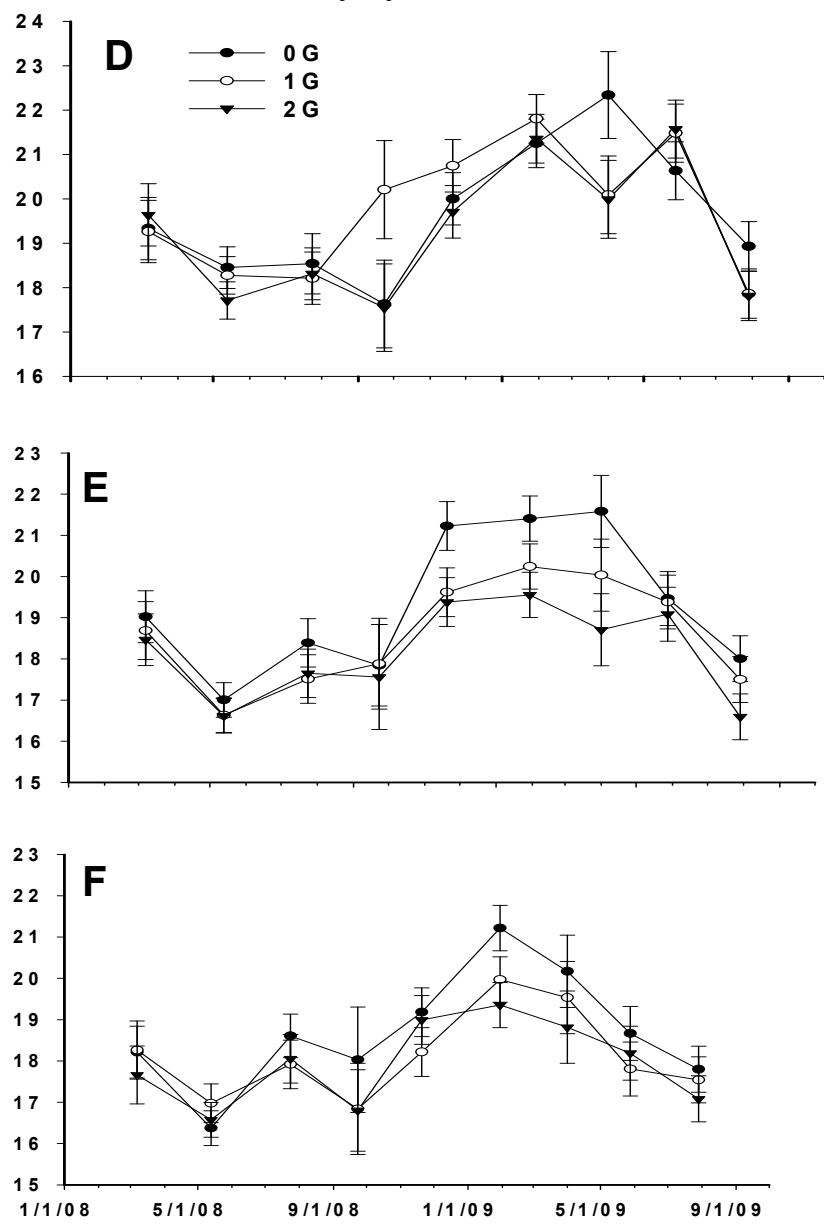

Figure 3.7. The interactive effects of fertilization and simulated grazing on (A,B,C) T. testudinum leaf C:N ratio, and (D,E,F) $S$. filiforme leaf C:N ratio (means \pm standard error). Asterisks indicate significant difference among treatments. ( $p<0.05$, Tukey's HSD test) 
T. testudinum leaf C:P
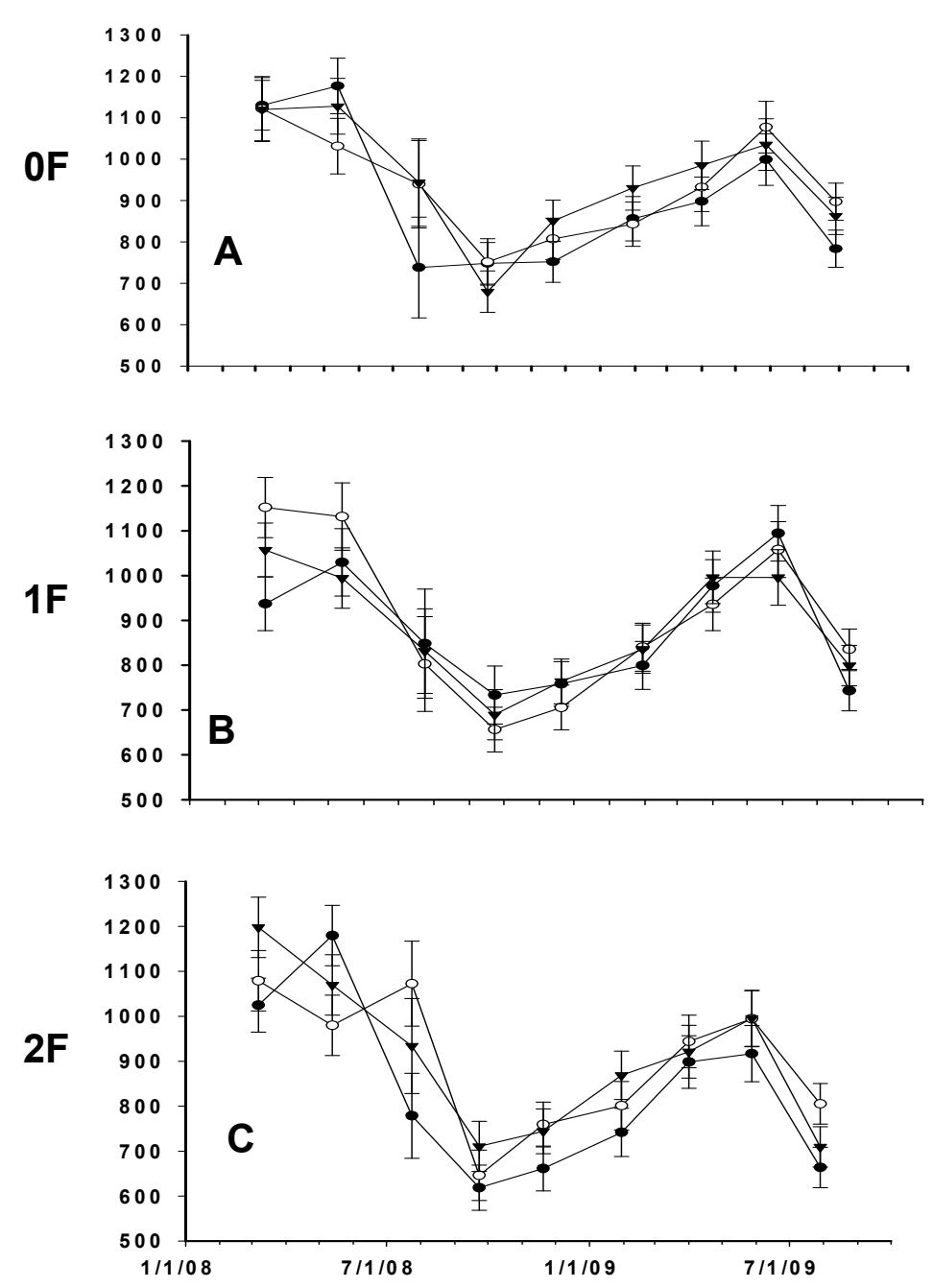

\section{S. filiforme leaf $\mathrm{C}: \mathrm{P}$}
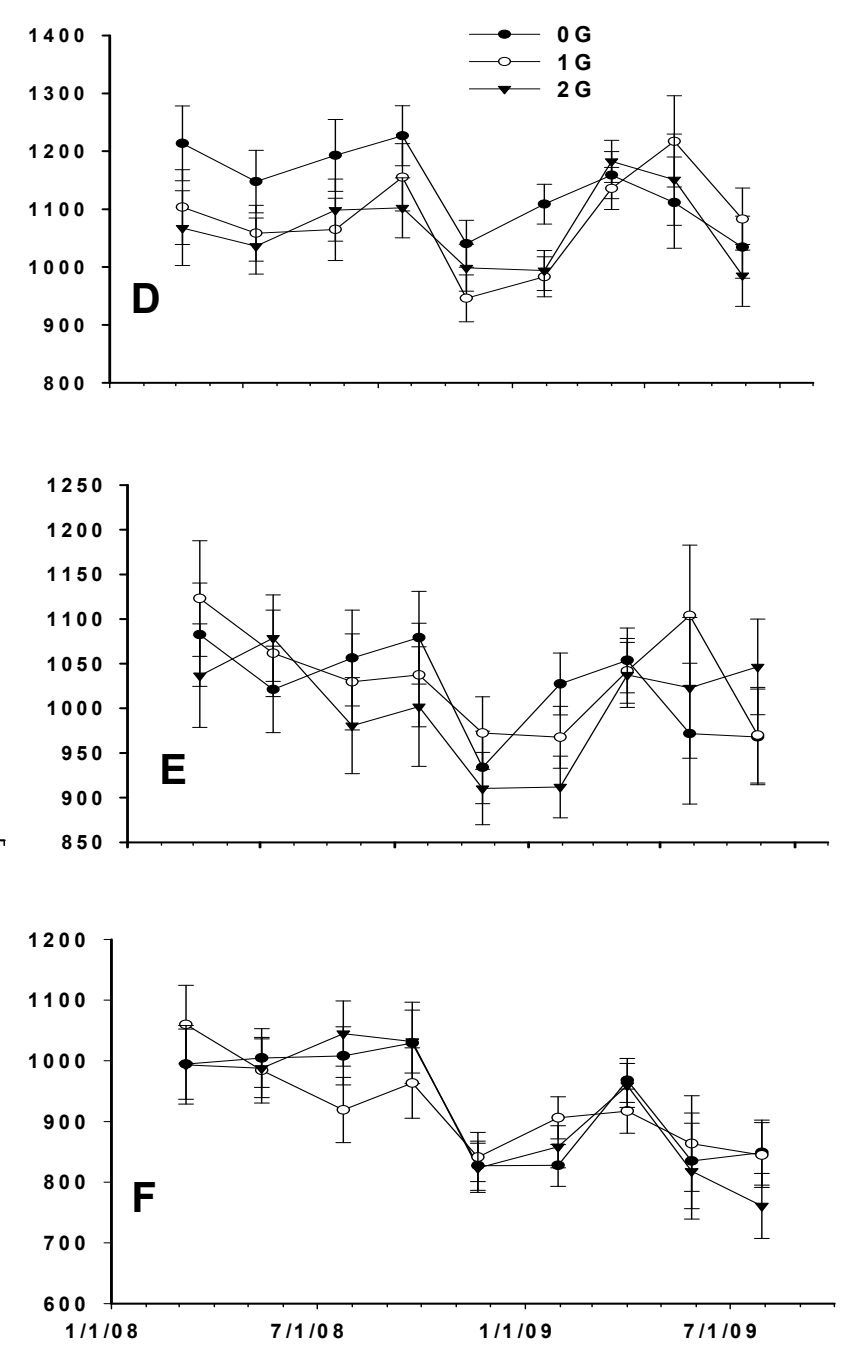

Figure 3.8. The interactive effects of fertilization and simulated grazing on (A,B,C) T. testudinum leaf leaf C:P ratio, and (D,E,F) $S$. filiforme leaf C:P ratio (means \pm standard error). Asterisks indicate significant difference among treatments. ( $<<0.05$, Tukey's HSD test) 

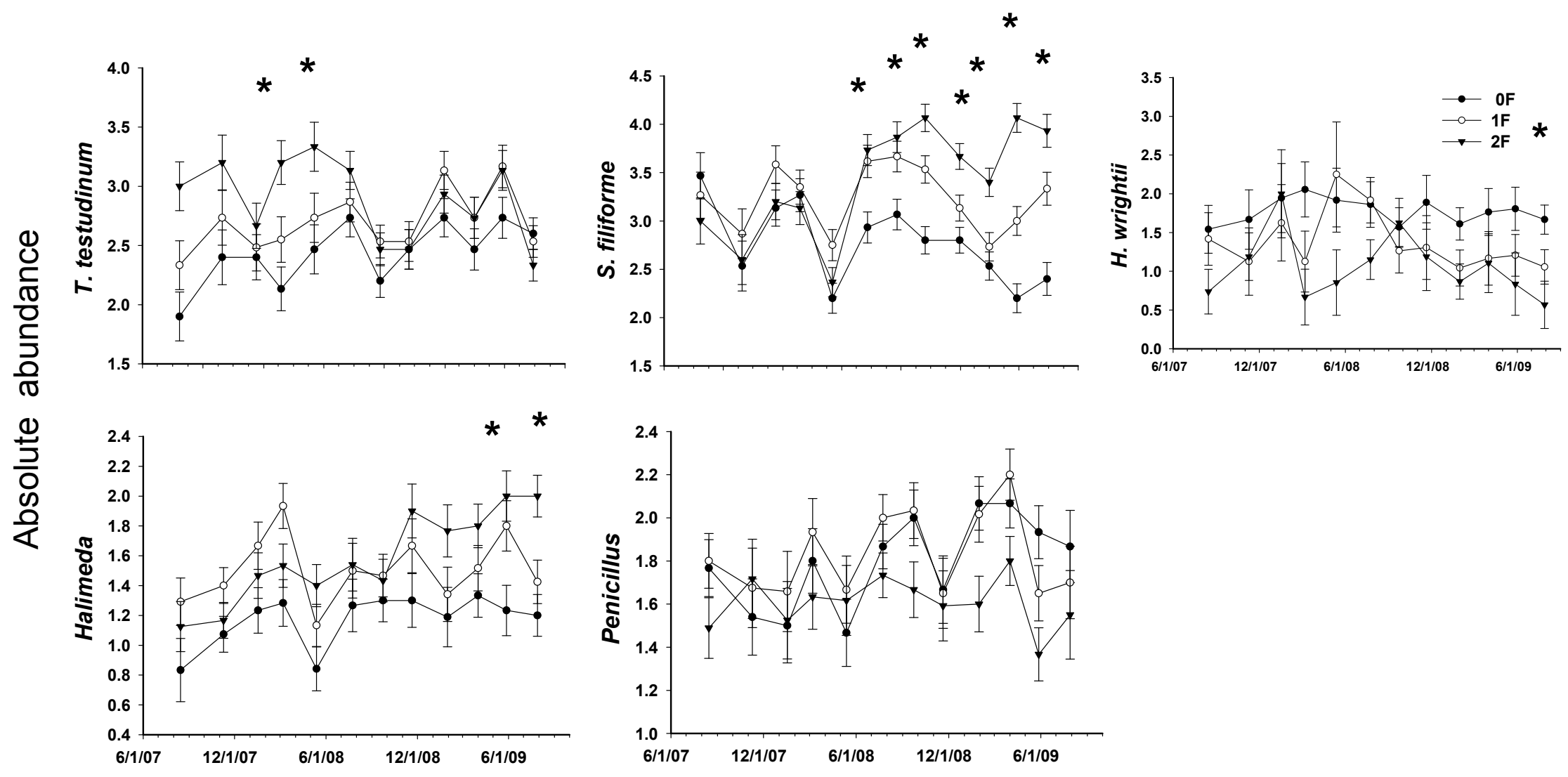

Figure 3.9. The effects of fertilization on the absolute abundance of (A) T. testudinum, (B) S. filiforme, (C) H. wrightii, (D) Halimeda, and (E) Penicillus (means \pm standard error). Asterisks indicate significant difference among treatments. ( $<0.05$, Tukey's HSD test) 

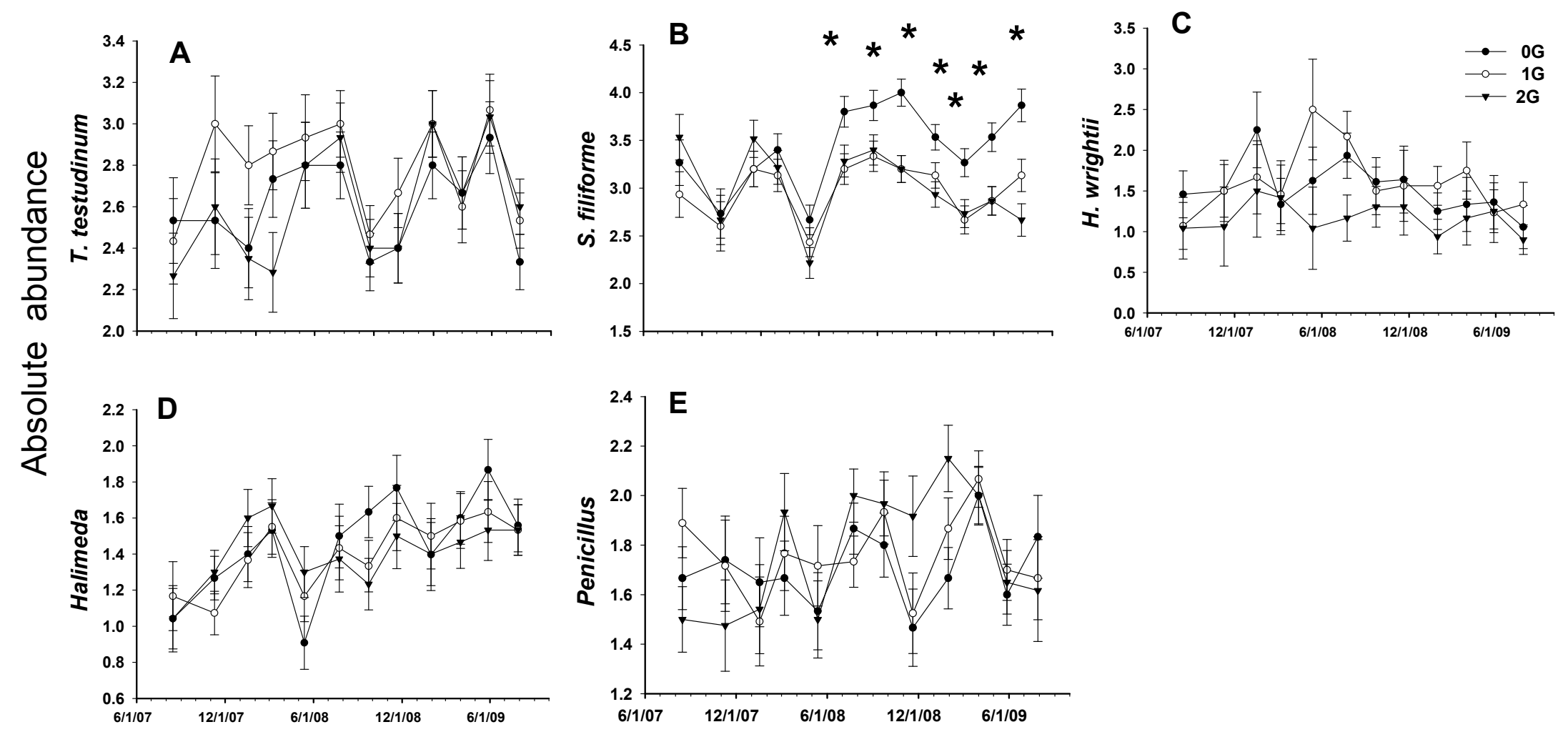

Figure 3.10. The effects of simulated grazing on the absolute abundance of (A) T. testudinum, (B) S. filiforme, (C) H. wrightii, (D) Halimeda, and (E) Penicillus (means \pm standard error). Asterisks indicate significant difference among treatments. ( $<<0.05$, Tukey's HSD test) 


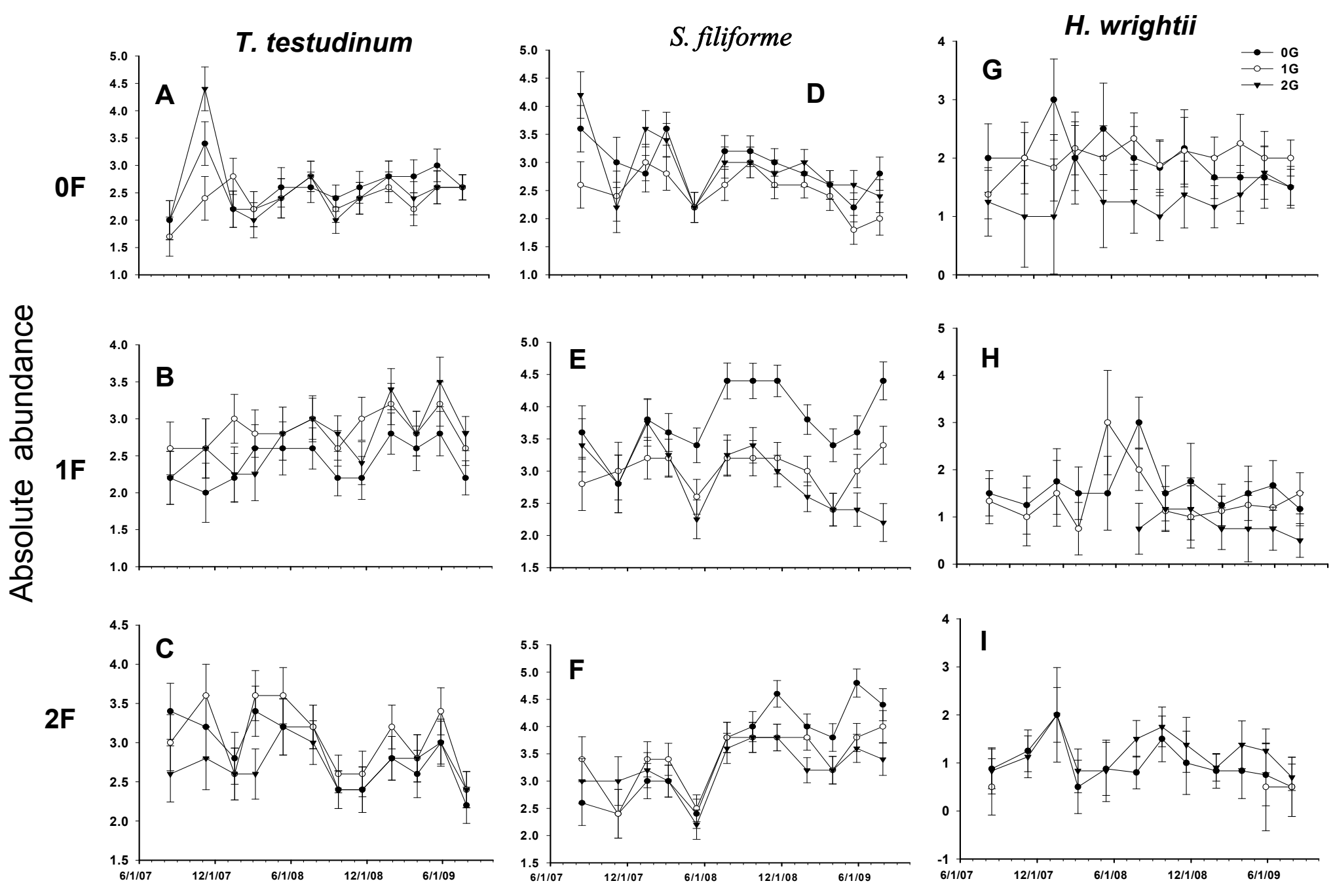

Figure 3.11. The interactive effects of fertilization and simulated grazing on the absolute abundance of (A, B, C) T. testudinum, (D, $\mathrm{E}, \mathrm{F}) \mathrm{S}$. filiforme, and (G, H, I) H. wrightii (means \pm standard error). 

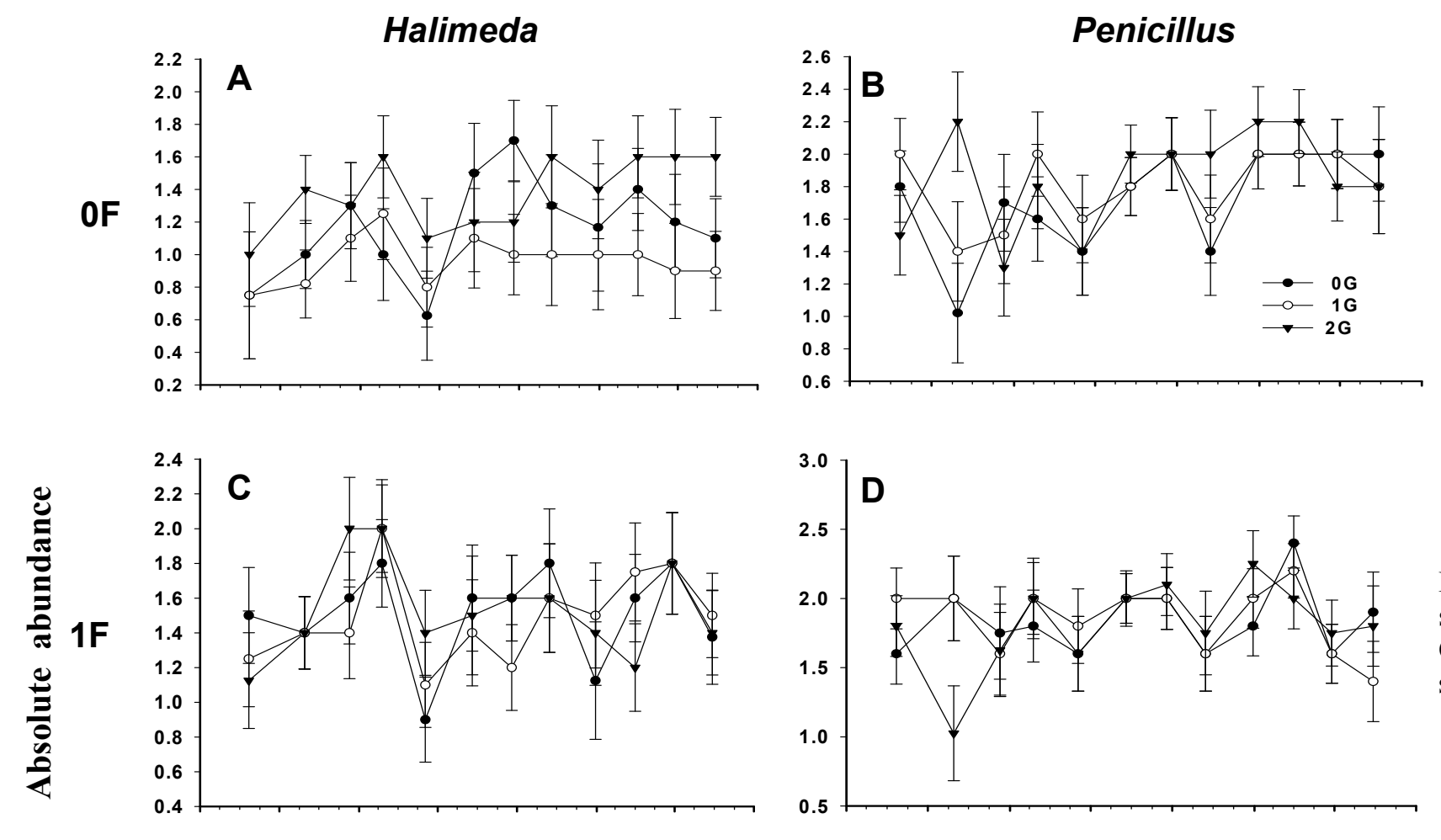

Figure 3.12. The interactive effects of fertilization and simulated grazing on the absolute abundance of (A, B, C) Halimeda, and (D, E, F) Penicillus (means \pm standard error).
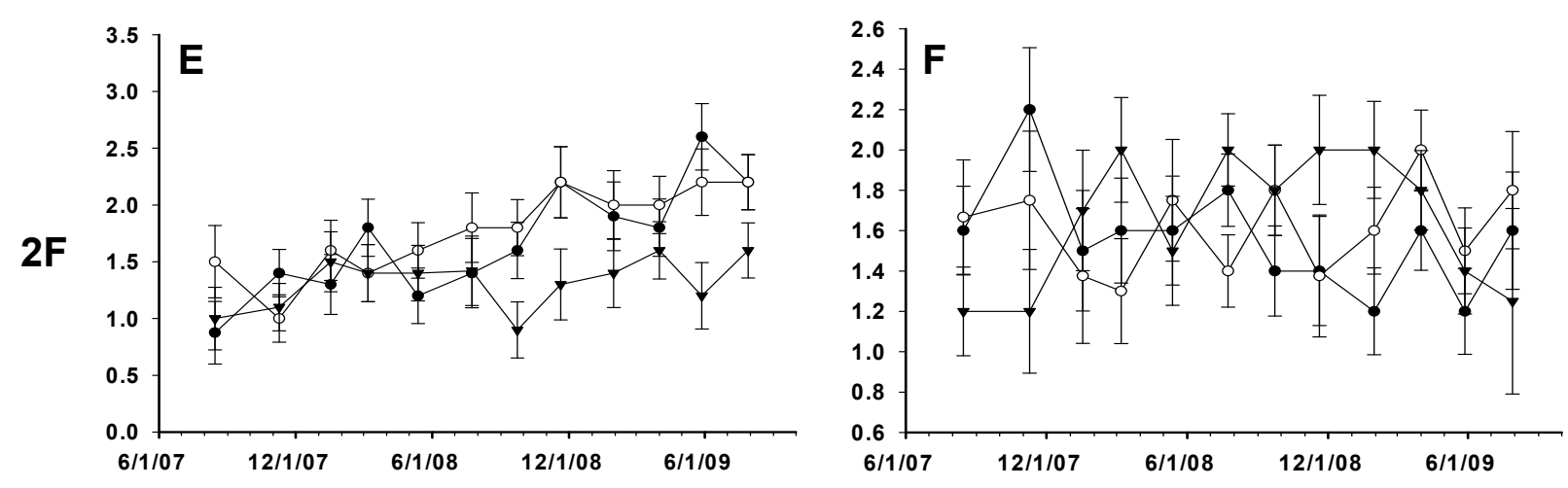

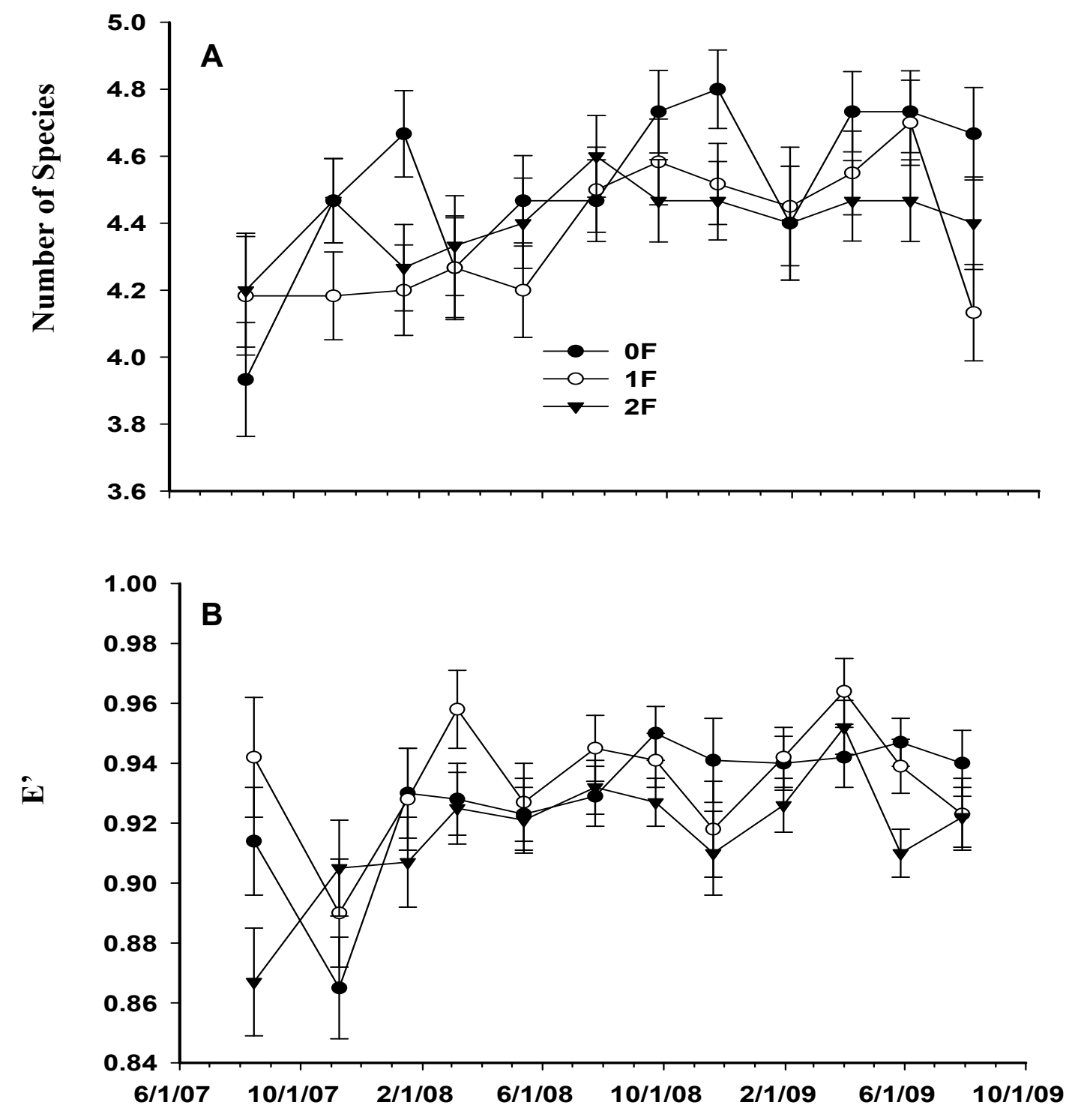

Figure 3.13. The direct effects of fertilization on (A) number of species (S) and (B) species evenness (E) (means \pm standard error). ( $\mathrm{p}<0.05$, Tukey's HSD test) 

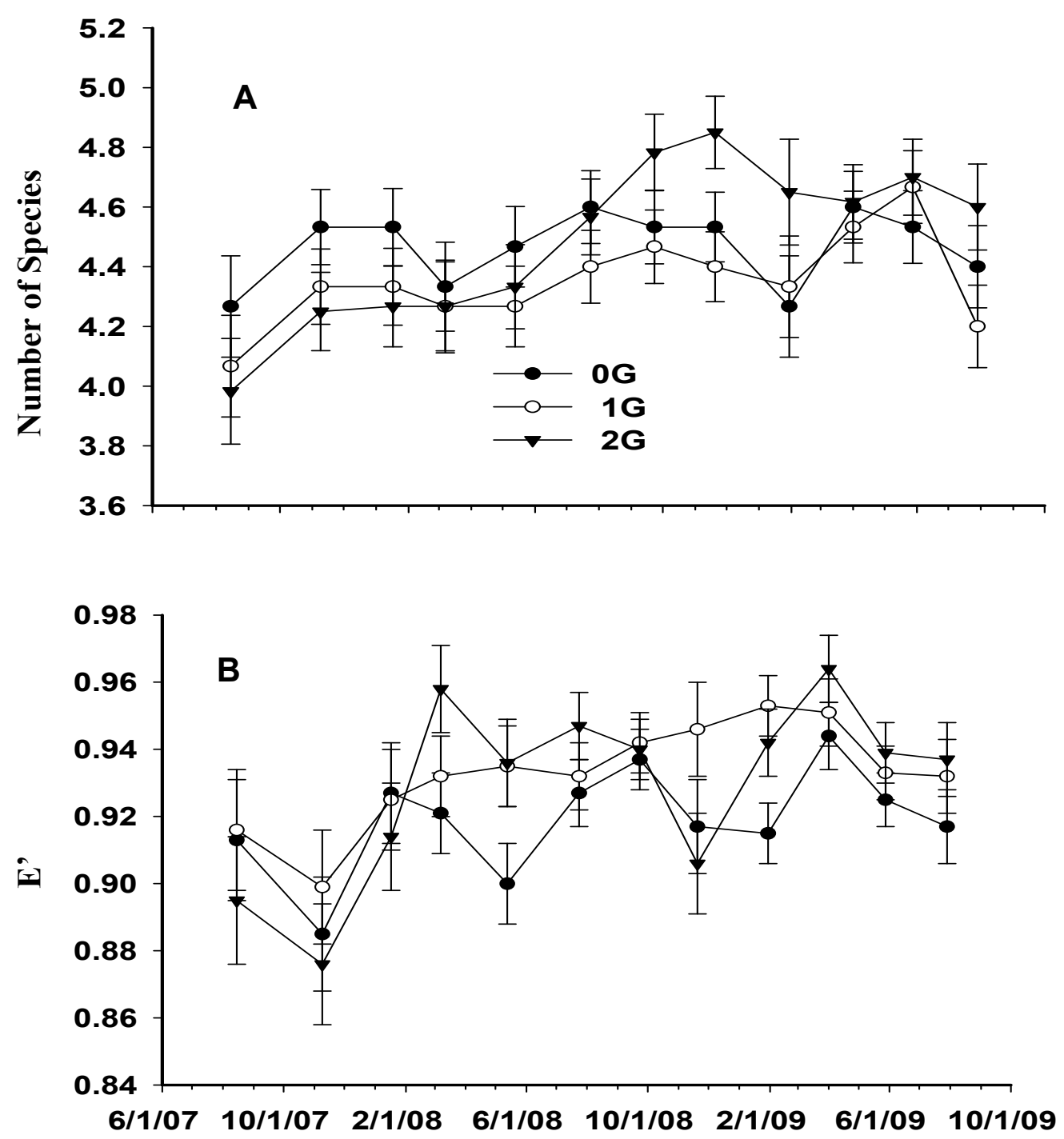

Figure 3.14. The direct effects of grazing on (A) number of species (S) and (B) species evenness (E) (means \pm standard error). ( $\mathrm{p}<0.05$, Tukey's HSD test) 

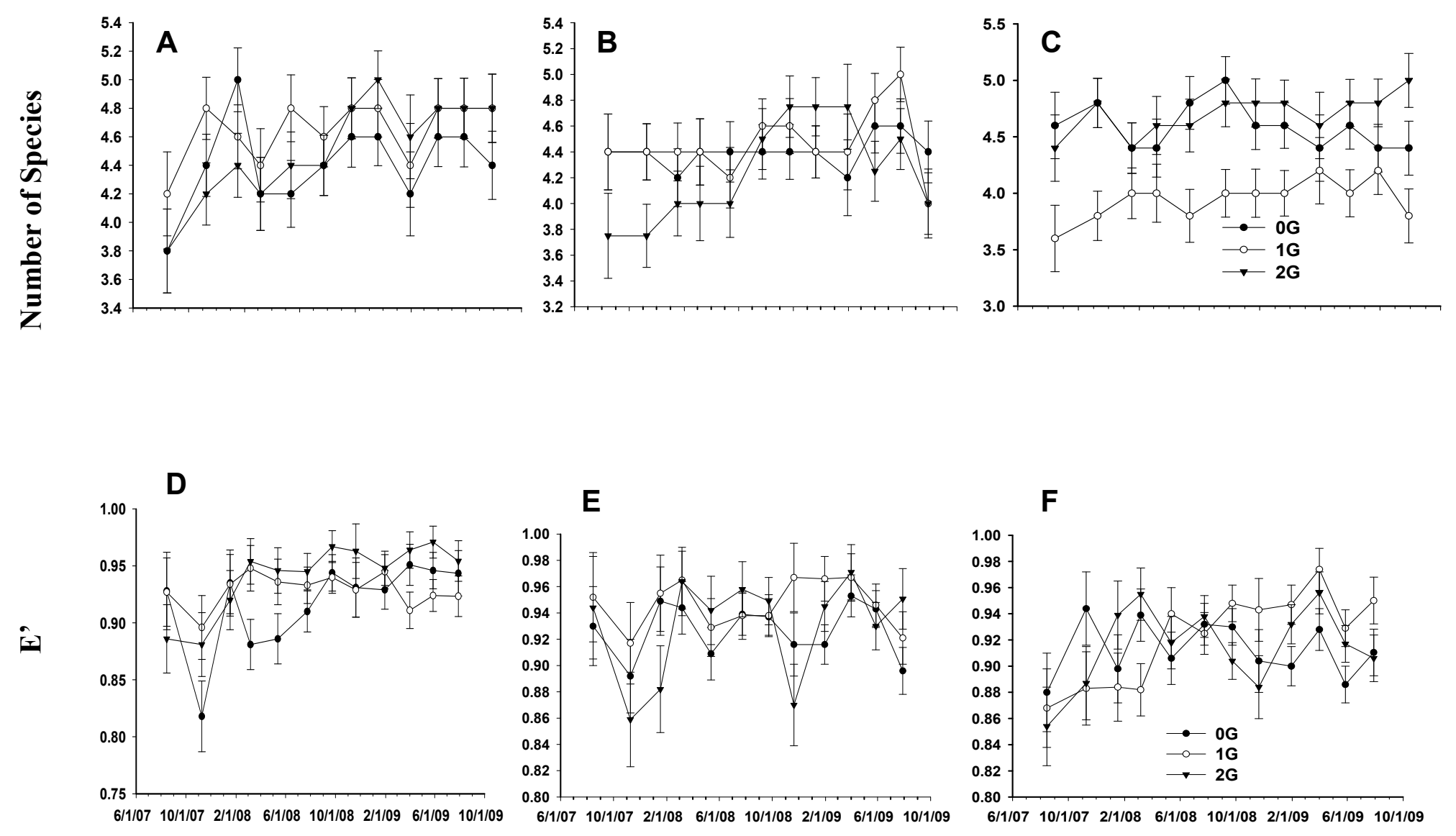

Figure 3.15. The interactive effects of fertilization and simulated grazing on (A, B, C) number of species (S) and (D, E, F) species evenness E (means \pm standard error). ( $\mathfrak{p}<0.05$, Tukey's HSD test) 


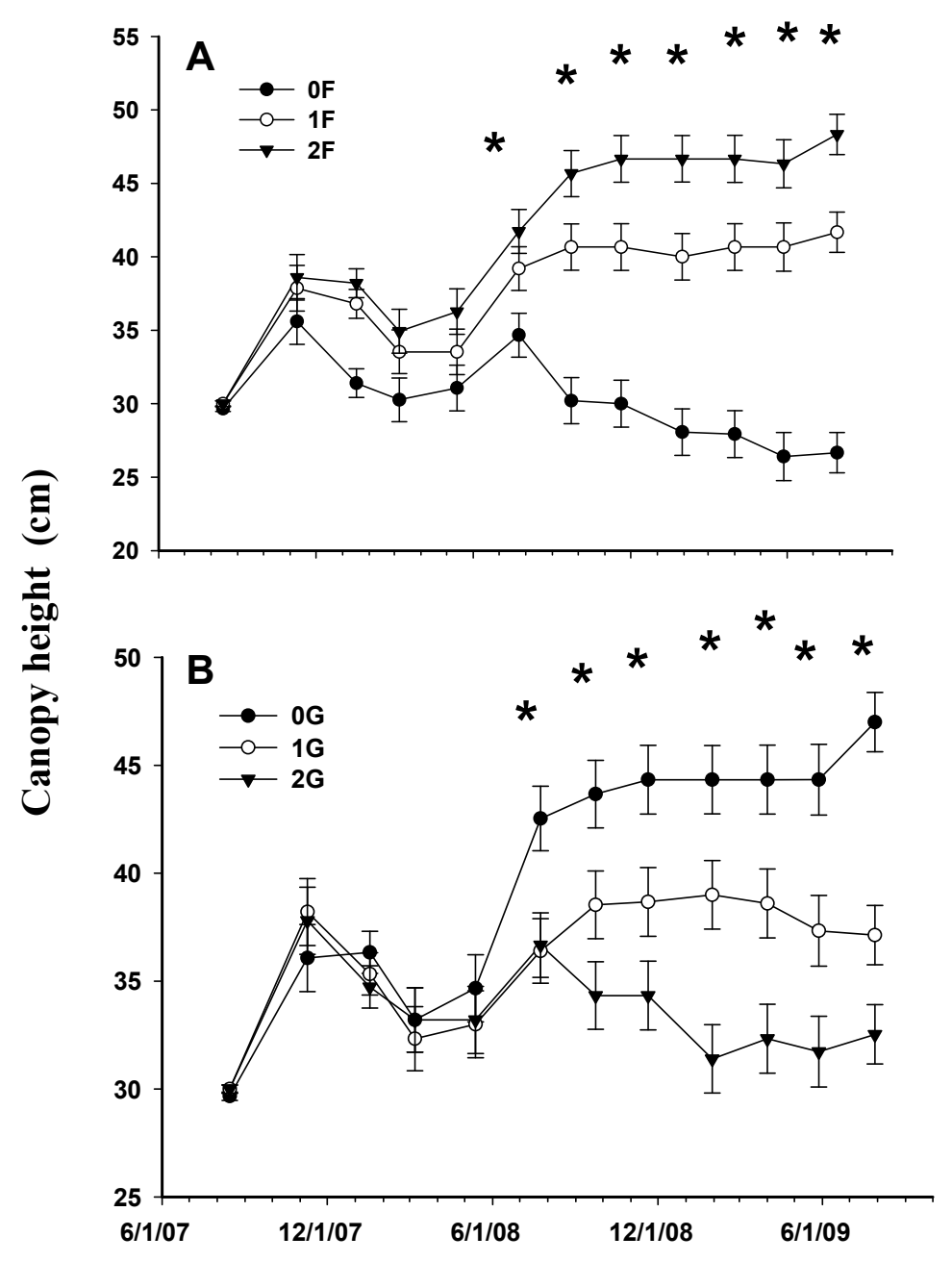

Figure 3.16. The effects of fertilization and simulated grazing on seagrass canopy height (means \pm standard error). Asterisks indicate significant difference among treatments. $(p<0.05$, Tukey's HSD test) 

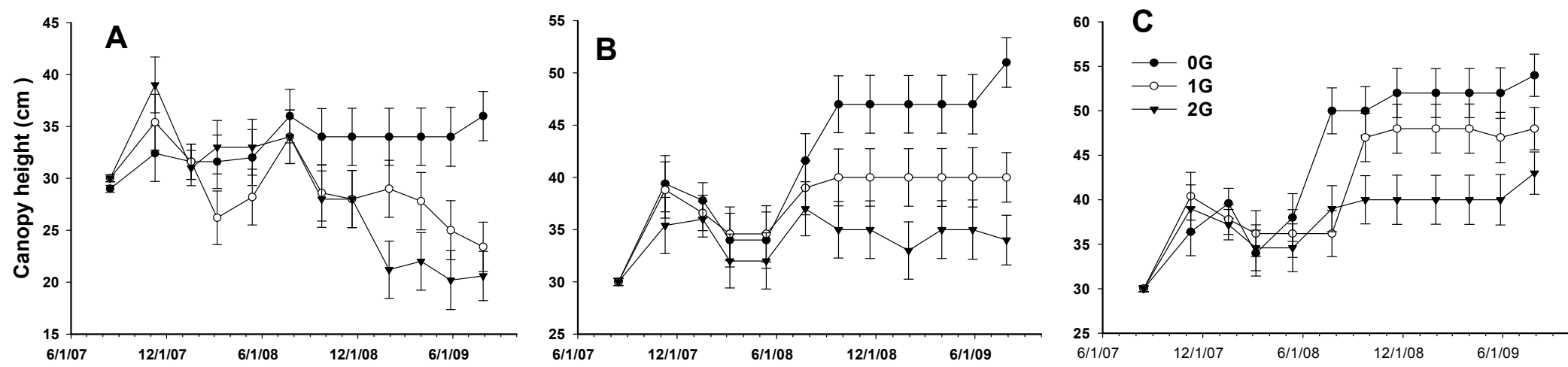

Figure 3.17. The interactive effects of fertilization and simulated grazing on seagrass canopy height (means \pm standard error). ( $p<0.05$, Tukey's HSD test) 
CHAPTER 4: THE EFFECTS OF FERTILIZATION AND SIMULATED GRAZING ON THE FLOWERING OF THE SEAGRASS SYRINGODIUM FILIFORME (KÜTZING)

\section{INTRODUCTION}

Seagrasses are marine flowering plants that grow fully submerged and have important ecological roles in coastal ecosystems (Costanza et al. 1997). Seagrasses have evolved distinct morphological, physiological and ecological adaptations to a completely submerged habit, including submarine pollination, marine dispersal internal gas transport and epidermal chloroplasts, (den Hartog 1970, Les et al. 1997). Seagrasses are capable of two modes of regeneration: sexual reproduction through seed and vegetative propagation (Hemminga and Duarte 2000). Seagrasses produce rhizomes with differentiated meristematic tissue enabling them to grow vegetatively along both horizontal and vertical axes (Tomlinson 1974, Duarte et al. 2006). Even though rates of sexual reproduction may be low in most seagrasses (Tomlinson 1974, Duarte et al. 2006), sexual reproduction in a clonal plant is important because it improves the quality of new clones, allows genetic variation and dispersal (Holderegger et al. 1998, Vallejo-Marin et al. 2010). Genetic diversity could increase the population's resilience and recovery from a disturbance (Hughes and Stachowicz 2004).

Syringodium filiforme is an important subtropical seagrass widely distributed throughout the southeastern U.S., Gulf of Mexico, and Caribbean Sea. It has highly differentiated rhizome architecture (Tomlinson 1974) and a relatively fast horizontal growth rate (Gallegos et al. 1994). The vertical stem of the S. filiforme population in 
Florida Bay grows an average of $17 \mathrm{~cm} \mathrm{yr}^{-1}$ (Kenworthy and Schwarzschild 1998). Short et. al. (1993) reported that S. filiforme produced an average of 32 new shoots per year and $78 \mathrm{~cm}$ of rhizome per year under experimental mesocosm conditions.

Reproductive processes in plants are usually synchronized with favorable seasons of the year (Yanovsky and Kay 2003) and floral initiation adjusted in response to day length and low temperature (Lang 1952). Syringodium filiforme, a dioecious plant (Cox et al. 1990) has been reported to flower from January to June in the Gulf of Mexico and which could be related to the winter temperature minima ranging from $22-24^{\circ} \mathrm{C}$ Caribbean (McMillan 1980b, Johnson and Williams 1982). Flowering in S. filiforme under controlled laboratory conditions was inhibited by shortening of day lengths to 11 hours (McMillan 1980). Entire short shoots of S. filiforme transform from vegetative short shoots to sexual, flowering short shoots (Kenworthy and Schwarzschild 1998). This appears to be a terminal event, as un-branched short shoots that flower have been observed to die soon after release of pollen or after seeds dropped (Kenworthy and Schwarzschild 1998). In Jack Bay, St. Croix (1981) found that the number of inflorescences of S. filiforme ranged from 250 to $1750 \mathrm{~m}^{-2}$.

Flowering frequency in seagrasses is highly variable among seagrass beds and the causes of this spatial variation are presently unknown but may be influenced by genetic variation or shoot age (Balestri and Vallerini 2003), distribution of active meristems, small-scale environmental changes or by temperature (McMillan 1980b, Marbà and Walker 1999, Campey et al. 2002, Diaz-Almela et al. 2007). McMillan (1980b) demonstrated that temperature is a major control of flowering in S. filiforme in a 
mesocosm experiment. The high variability in flowering frequency among different seagrass beds and the non-flowering of clones in the lab grown under inductive temperature and photoperiod conditions suggest that nutrient conditions may also play a role in flowering (McMillan 1976, 1980a, Gobert et al. 2005).

Several factors may directly or indirectly affect sexual reproduction in clonal plants, for example light, nutrient availability, disturbance, competition and herbivory (Durako and Moffler 1987, Wilson and Tilman 1991, Vilà and Terradas 1995, Piazzi et al. 2000, Gobert et al. 2005, Diaz-Almela et al. 2007, Brys et al. 2010). These factors could also influence resource allocation between vegetative growth and sexual reproduction (Abrahamson 1980, Loehle 1987, Lovett Doust 1989). Trade-off between these two reproductive modes could influence how the plant population will respond to changes in environmental conditions. To date, there is a very little information available on the effects of changing nutrient availability and herbivory on seagrass flowering.

Seagrass beds have been subjected to increased nutrient and sediment runoff, hydrological alterations, and detrimental commercial fishing practices in recent years (Orth et al. 2006). For example, seagrass decline has been attributed to nutrient enrichment that leads to light reduction through stimulation of algal growth (Duarte 1995, Deegan et al. 2002). This is further exacerbated by the loss of large consumers by overfishing (Jackson 2001). With the recognition that sexual reproduction is important in maintaining genetic diversity, it is important to investigate the effects of increased nutrient loading and herbivore loss on the flowering of seagrasses. 
In this study, I assessed if vegetative and sexual reproduction in S. filiforme changed with nutrient availability and simulated herbivory in a mixed subtropical seagrass bed. I quantified the effect of fertilization, simulated grazing and the interaction between fertilization and simulated grazing on a) absolute abundance of the seagrasses; b) the carbon, nitrogen and phosphorus content of T. testudinum leaves and S. filiforme leaves and flowers; c) number of flowering shoots of S. filiforme per square meter; d) number of flowers per shoot produced by S. filiforme; b) the male:female floral sex ratio.

\section{METHODS}

The experiment started in August 2007 and was terminated in July 2009.

Experimental plots $\left(1 \mathrm{~m}^{2}\right)$ were established in a shallow water $(1.5 \mathrm{~m})$ seagrass meadow comprised of Thalassia testudinum, Syringodium filiforme, and Halodule wrightii growing in a muddy sand sediment on the southwestern side of Florida Bay (N 24 51.01, W 80 53.190). The plots were situated $1 \mathrm{~m}$ apart in a $3 \times 3$ factorial design: 3 fertility levels (control (C), medium NP (1F) and high NP (2F) x 3 grazing levels (0, 25 and $50 \%$ biomass removal $(1 \mathrm{G}$ and $2 \mathrm{G}))$ x 5 replicates for each treatment $=45$ plots. Nitrogen was added into the sediment using slow release nitrogen fertilizer pellets (Polyon ${ }^{\mathrm{TM}}$, Purcell Technologies inc., 38-0-0) and phosphorus was added as granular phosphate rock (Multifos $^{\mathrm{TM}}$, IMC Global, $\left.\mathrm{Ca}_{3}\left(\mathrm{Po}_{4}\right)_{2}, 18 \% \mathrm{P}\right)$. Fertilization and simulated grazing were carried out every two months. The fertilizer loading rate in the $1 \mathrm{~F}$ plots was $2.4 \mathrm{mg} \mathrm{N}$ day $^{-1}$ and $80 \mu \mathrm{g} \mathrm{P}_{\text {day }}{ }^{-1}$ and in the $2 \mathrm{~F}$ plots was $4.8 \mathrm{mg} \mathrm{N}$ day $^{-1}$ and $160 \mu \mathrm{g} \mathrm{P}$ day $^{-1}$. These loading rates are four and eight times the nitrogen and phosphorus requirement of $T$. testudinum, which has the lowest nutrient requirement among the three species 
(Fourqurean et al. 1992). Since the $\mathrm{N}$ and $\mathrm{P}$ requirement of $\mathrm{H}$. wrightii, which has the highest nutrient requirement among the three species, is twice and four times that of $T$. testudinum (Fourqurean et al. 1992), these loading rates will ensure that the nutrient requirements of all three species are met. Turtle grazing was simulated by clipping of aboveground biomass of the three seagrass species with stainless steel garden shears to about $5 \mathrm{~cm}$ above the sediment leaving the meristems on the horizontal rhizomes intact. . I chose to simulate turtle grazing because turtles have been reported to graze on all three seagrass species (Mortimer 1981, Williams 1988). Turtles have also been observed to create discrete grazing plots in seagrass beds and return to these plots to harvest new growth (Bjorndal 1980). I subdivided the one square meter plot into sixteen $0.25 \times 0.25$ cm quadrats. Then I clipped the above-ground biomass in eight and sixteen randomly chosen $0.25 \times 0.25$ qaudrats for the medium (25\%) and high (50\%) grazed plots, respectively.

In April 2009, S. filiforme in the experimental plots flowered and so I counted the number of flowering and non-flowering shoots of S. filiforme in three $25 \times 25 \mathrm{~cm}$ quadrats in each experimental plot. Then I collected 5-10 inflorescences in each 25 x 25 $\mathrm{cm}$ quadrat, stored them in ice and transported them back to the laboratory. I counted the number of flowers on each inflorescence and determined if the inflorescence was male or female. I also collected shoots of S. filiforme and T. testudinum for morphological measurements of the leaves and CNP analysis. The seagrass shoots were collected prior to clipping because I was interested in evaluating the responses of the plants to grazing. The epiphytes on the leaf material of each species were gently scraped off with a razor blade. The flowers and leaves were dried at $70^{\circ} \mathrm{C}$, weighed, ground to a fine powder and 
analyzed for carbon (C), nitrogen $(\mathrm{N})$ and phosphorus $(\mathrm{P})$. For each species within each plot, seagrass leaf material was pooled. Carbon and nitrogen content were determined using a $\mathrm{CHN}$ analyzer. Phosphorus content was determined by a dry-oxidation, acid hydrolysis extraction followed by colorimetric analysis (Fourqurean et al. 1992a). Elemental content and ratios were calculated on a dry weight and mole:mole basis, respectively.

\section{ANALYSIS}

The effects of fertilization and grazing on the leaf elemental content, leaf morphology, number of flowers per shoot, number of flowering shoots per square meter, percent flowering shoots of S. filiforme and absolute cover of the seagrasses were tested using a full factorial 2-way ANOVA (nutrient, grazing and nutrient $\mathrm{x}$ grazing) (Proc GLM in SAS 9.2). If necessary, data were log-transformed to achieve normality (Kolmogorov-Smirnoff test) and homogeneity of variances (Bartlett's test). For factors with significant effects, I compared means using Tukey's test. The comparison was considered statistically significant at $\mathrm{p} \leq 0.05$.

\section{RESULTS}

Absolute abundance of seagrasses

Fertilization and simulated grazing had no significant effect on the absolute abundance of $T$. testudinum and $H$. wrightii in our experimental plots at the time of sampling (Figure 4.1a and c, Table 4.1). The absolute abundance of S. filiforme increased by 39 and $64 \%$ in the $1 \mathrm{~F}$ and $2 \mathrm{~F}$ plots, respectively (Figure $4.1 \mathrm{~b}$, Table 4.1 ).. 
Clipping decreased the absolute abundance of S. filiforme by 24 and $45 \%$ in the $1 \mathrm{G}$ and $2 \mathrm{G}$ plots (Figure $4.1 \mathrm{~b}$, Table 4.1 ). There were no interactive effects of simulated grazing and fertilization on the on the absolute abundance of the three seagrass species: grazing had the same relative effect on absolute abundance across all levels of fertility and fertilization had the same relative effects across all levels of grazing (Figure 4.1, Table 4.1).

Syringdium filiforme leaf length and leaf mass

The leaf length of S. filiforme was $17 \%$ and $15 \%$ longer in the $1 \mathrm{~F}$ and $2 \mathrm{~F}$ plots, respectively than in the control plots (Figure 4.2a, Table 4.1). The leaf mass per short shoot of S. filiforme increased by $6 \%$ and $50 \%$ in the $1 \mathrm{~F}$ and $2 \mathrm{~F}$ plots, respectively (Figure 4.2b, Table 4.1). Simulated grazing decreased the leaf length of S. filiforme by $10 \%$ and $17 \%$ in the $1 \mathrm{G}$ and $2 \mathrm{G}$ plots, respectively but had no effect on its leaf mass (Figure 4.2a and b, Table 4.1). There were no interactive effects of grazing and fertilization on the leaf length and leaf mass of S. filiforme: grazing had the same relative effect on leaf length and leaf mass across all levels of fertility and fertilization had the same relative effects across all levels of grazing (Figure 4.2a and b, Table 1).

CNP content of S. filiforme leaf and flowers

Fertilization had no significant effect on the leaf and flower N content of $S$. filiforme (Figure 4.3a and b, Table 1). Clipping increased leaf N content of S. filiforme by 9 and $12 \%$ in the $1 \mathrm{G}$ and $2 \mathrm{G}$ plots (Figure $4.3 \mathrm{a}$, Table 1 ). The flower $\mathrm{N}$ content $S$. filiforme in the $1 \mathrm{G}$ and $2 \mathrm{G}$ plots were 5 and $12 \%$ higher, respectively than in the control plots (Figure 4.3b, Table 1). The leaf P content of S. filiforme increased by 13 and $23 \%$ 
in the $1 \mathrm{~F}$ and $2 \mathrm{~F}$ plots, respectively while clipping had no significant effect on leaf $\mathrm{P}$ content of S. filiforme (Figure 4.3b, Table 4.1) There was no interactive effect of fertilization and clipping on leaf and flower N content of S. filiforme (Figure 4.3c, Table 4.1). The P content of the flowers did not respond to any of the treatments (Figure 4.4, Table 4.1).

Syringodium filiforme flower

Fertilization decreased the percent flowering of S. filiforme shoots by $21 \%$ and 68 $\%$ in the $1 \mathrm{~F}$ and $2 \mathrm{~F}$ plots, respectively but had no effect on the number of flowers per shoots and the number of flowering shoots per square meter (Figure 4.4a, b and c, Table 4.1). Seven, six and four percent of the shoots in the control, $1 \mathrm{~F}$ and $2 \mathrm{~F}$ plots flowered, respectively. Clipping decreased percent flowering by $92 \%$ and $210 \%$ in the $1 \mathrm{G}$ and $2 \mathrm{G}$ plots, respectively (Figure 4.4a, Table 1). The number of flowering shoots per square meter was $147 \%$ and $780 \%$ lower in the $1 \mathrm{G}$ and $2 \mathrm{G}$ plots, respectively than the control plots (Figure $4.4 \mathrm{c}$, Table 1). The number of flowers per shoot decreased by $100 \%$ and $233 \%$ in the $1 \mathrm{G}$ and $2 \mathrm{G}$ plots, respectively (Figure $4.4 \mathrm{~b}$, Table 1 ). The number of flowers per shoot in S. filiforme responded to the interactive effects of fertilization and grazing (Figure 4.4a, $\mathrm{b}$ and $\mathrm{c}$, Table 4.1). The number of flowers per shoot was greater in the fertilized but unclipped plots ( $\mathrm{p}=0.012$, Figure $4.4 \mathrm{a}, \mathrm{b}$ and $\mathrm{c}$ ). I only found female flowers.

\section{DISCUSSION}

This study showed that vegetative growth and sexual reproduction could be significantly affected by nutrient availability and grazing. Although nutrient addition did 
not affect the absolute abundance of $T$. testudinum and $H$. wrightii, it increased the leaf mass, leaf length and absolute abundance $S$. filiforme in the enriched plots. A similar increase in aboveground biomass of $S$. filiforme was reported in a fertilization experiment in the Carribean and Florida Keys (Williams 1987, Armitage et al. 2011).

Species often time their sexual reproduction with periods of environmental uncertainty, and reproduce asexually when conditions are more favorable (Loehle 1987, Silvertown 2008). The increase in the shoot abundance of $S$. filiforme in the fertilized plots, with no concomitant increase in inflorescence production supports this view. The plants invested more on vegetative growth, which is less costly than sexual reproduction and allows the plant to expand faster and be more competitive (Loehle 1987). Nutrient addition in a Mediterranean shrub community caused an increase in biomass allocation to new sprouts, but decreased the frequency of sprout flowering (Vilà and Terradas 1995). Fertilization could increase competition between $T$. testudinum and S. filiforme for light and space (Williams 1987(Ferdie and Fourqurean 2004)), so it is advantageous to invest resources in shoot production rather than on inflorescence production. Plants increase their capacity to acquire more resources as they build above- and belowground material (Watson 1984a).

A trade-off in meristem allocation between flowering and vegetative growth is particularly conspicuous in plants with determinate inflorescences (Watson 1984a, Huber and During 2000). When the apical meristem of a tiller develops into a floral primordium, the tiller becomes unavailable for vegetative growth, and dies after reproduction. It could be expected that intense flowering could negatively impact vegetative growth of a plant 
as sexual reproduction involves a loss of existing meristems. The increase in the number of flowers per shoot in fertilized plots that were unclipped could be a mechanism to increase sexual reproduction without increasing shoot mortality due to reproduction.

Gobert et al. (2005) reported that the leaf $\mathrm{N}$ and $\mathrm{P}$ content of non-flowering shoots of Posidonia oceanica was greater than in flowering shoots but the $\mathrm{N}$ and $\mathrm{P}$ content of inflorescences was similar to intermediate leaves of non-flowering plants. Their results also show that the daily P requirement of flowering shoots is higher than that of nonflowering shoots of Posidonia oceanica. This suggests that flowering requires additional nutrients. If resources are limited, resources have to be allocated to the physiological function that would increase the survival of the individual and resources allocated to other functions will be diminished (Watson 1984b, Lovett Doust 1989). Thus, investing in vegetative expansion to compete for space and nutrients with the other species would reduce the available resources for sexual reproduction (Watson 1984b). The decrease in shoot abundance and loss of foliage in S. filiforme due to clipping could result in a reduction in photosynthetic capacity and depletion of carbohydrate reserves. A decrease in photosynthetic activity would reduce available resources for vegetative and sexual reproduction. The increase in leaf $\mathrm{N}$ content in the grazed plots did not translate to an increase in leaf size or absolute abundance, so the extra $\mathrm{N}$ must have been used for flower production. Although there was an increase in $\mathrm{N}$ content of the flowers in the clipped plots, it was not enough to enhance flower production as shown by the decrease in the number of flowering shoots per square meter, number of flowers per shoot and percent flowering. 
The reduction in the shoot abundance, leaf size and flowering suggest that clipping incurred costs to both flowering and survival. Grazing has been shown to negatively impact flowering. Shoot growth and flowering in prairie grasses decreased in response to cattle grazing (Hickman and Hartnett 2002). Clam harvesting disturbance decreased sexual reproduction in Zostera noltii in Ria Formosa, Portugal (Alexandre et al. 2005). The flowering frequency of a clonal forest herb decreased when grazed by deer (Rooney 1997). Although, clipping negatively impacted flowering in this study, clipping may enhance shoot recruitment by creating gaps that could be colonized by seedlings.

The absence of male flowers in the plots suggests that the sampling area is comprised of female clones. Johnson and Williams (1982) reported that they found two stands of S. filiforme bearing either $100 \%$ female or $100 \%$ male flowers in Jacks Bay, St. Croix. Cox et al. (1990) also reported that S. filiforme in most of their sampling plots along a depth gradient were unisexual. In the cases studied, male individuals are usually more common in the more highly stressed habitats along gradients of salinity, moisture, nutrients, light, and temperature (Freeman et al. 1976, Cox 1981, Lovett Doust and Laporte 1991). Female inflorescences of S. filiforme were found to be more abundant in shallow water while male flowers were more abundant in deeper waters (Cox et al. 1990). I may also have missed collecting the male flowers because I only sub-sampled the plots. I did not see any seed set (pers. obs.), which also suggests males were absent.

The results of this study suggest that nutrient addition and grazing could negatively impact flowering in seagrasses. Species with determinate inflorescence are particularly vulnerable to the effects of fertilization and grazing because allocation of a 
meristem to flowering would mean a loss of that meristem. The relative importance of sexual versus vegetative recruitment in a plant population could determine its survival. A decrease in sexual reproduction may strongly affect the plant's adaptation to local environments and their geographic distribution. Asexual reproduction allows populations to persist in habitats or regions where, for one reason or another, sexual reproduction cannot occur. Asexual reproduction does not involve recombination and, therefore, yields offspring that are genetically identical to each other and to the plant that produced them. The depletion of genotypic variability within clonal populations through time makes them more susceptible to diseases, pathogens, and environmental stochasticity (Chapin et al. 1997, Hughes and Stachowicz 2004). 
Table 4.1. ANOVA results of effects of nutrients and grazing on response variables measured in April 2009. Significant effects (defined as $p \leq 0.05$ ) are designated in boldface type.

\begin{tabular}{lllll}
\hline Response & Nutrient $(\mathrm{F})$ & Grazing $(\mathrm{G})$ & $\mathrm{F} \times \mathrm{G}$ \\
$\begin{array}{l}\text { variables } \\
\mathrm{P}\end{array}$ & $\mathrm{F}_{45}, \quad \mathrm{P}$ & $\mathrm{F}_{45,2}$ & $\mathrm{P}$ & $\mathrm{F}_{45,4}$ \\
\hline
\end{tabular}

\section{Thalassia testudinum}

\begin{tabular}{|c|c|c|c|c|c|c|}
\hline Absolute abundance & 0.78 & 0.47 & 0.05 & 0.95 & 0.63 & 0.64 \\
\hline \multicolumn{7}{|l|}{ Syringodium filiforme } \\
\hline Leaf $N$ & 2.6 & 0.09 & 5.67 & 0.007 & 0.29 & 0.88 \\
\hline Leaf P & 25.7 & $<0.001$ & 4.66 & 0.016 & 0.35 & 0.84 \\
\hline Flower N & 1.30 & 0.29 & 3.74 & 0.034 & 0.39 & 0.82 \\
\hline flowering shoots $\mathrm{m}^{-2}$ & 1.98 & 0.15 & 16.78 & $<0.001$ & 2.37 & 0.07 \\
\hline flowers shoot ${ }^{-1}$ & 0.33 & 0.72 & 20.89 & $<0.001$ & 3.42 & 0.018 \\
\hline$\%$ flowering & 3.34 & 0.047 & 16.85 & $<0.001$ & 0.63 & 0.64 \\
\hline Leaf mass (mg SS$\left.{ }^{-1}\right)$ & 6.07 & 0.006 & 0.83 & 0.44 & 0.55 & 0.69 \\
\hline Leaf length $(\mathrm{cm})$ & 12.00 & $<0.001$ & 4.22 & 0.024 & 0.22 & 0.93 \\
\hline Absolute abundance & 9.59 & $<0.001$ & 5.03 & 0.012 & 1.1 & 0.37 \\
\hline \multicolumn{7}{|l|}{ Halodule wrightii } \\
\hline Absolute abundance & 1.01 & 0.38 & 0.48 & 0.62 & 0.61 & 0.62 \\
\hline
\end{tabular}




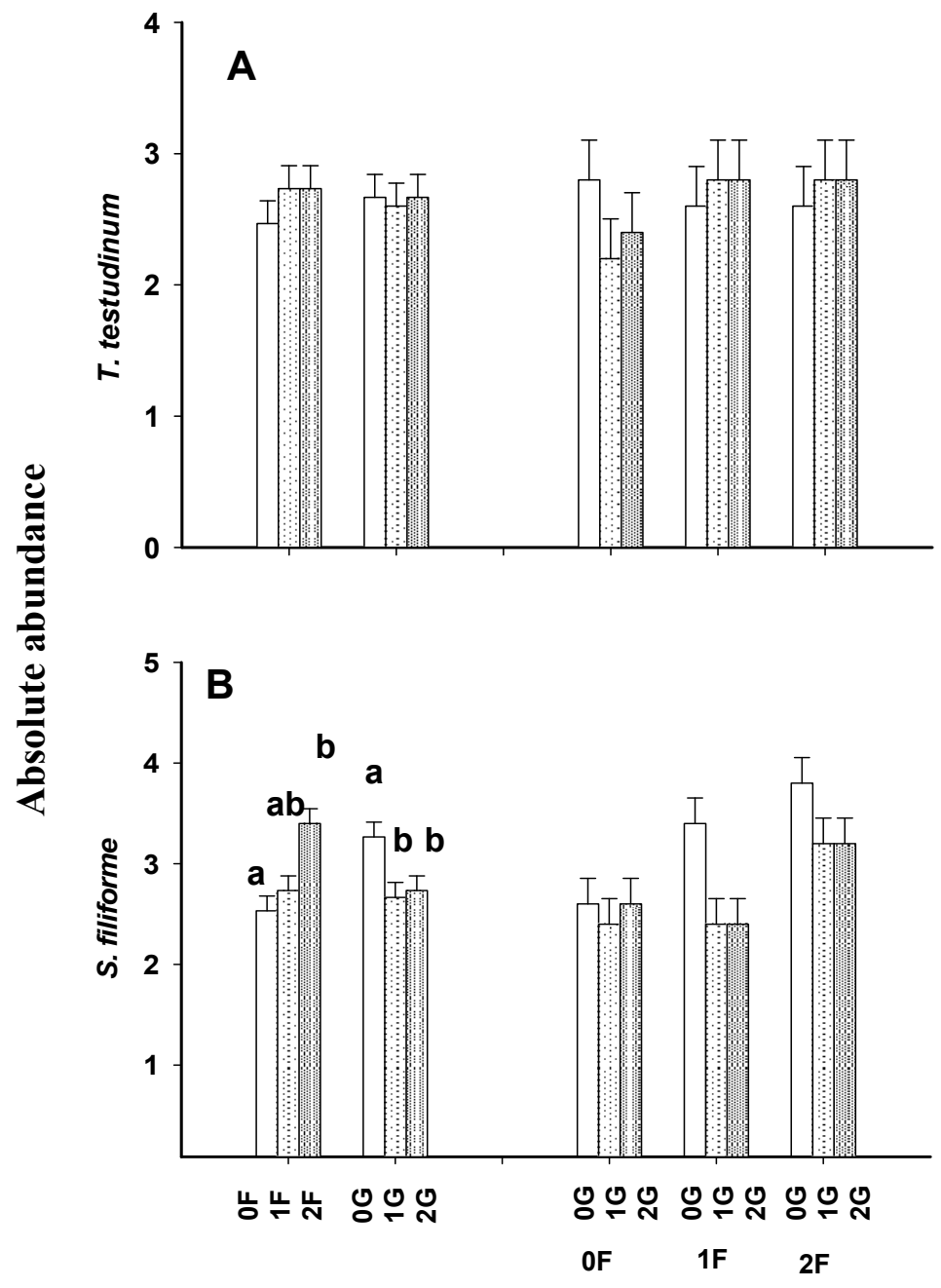

Main effects

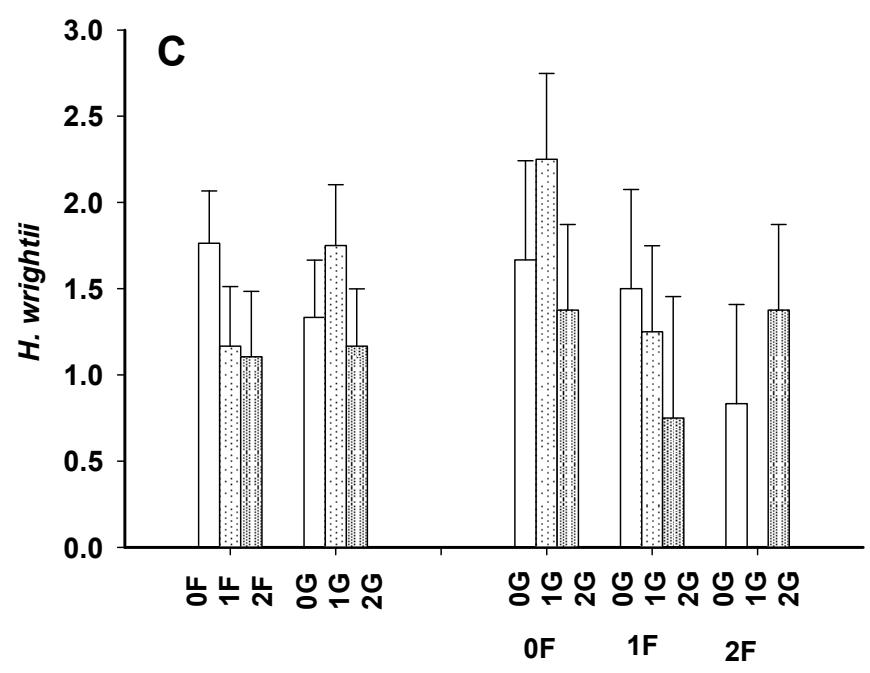

Main effects

Interaction

Figure 4.1. The direct and interactive effects of fertilization and simulated grazing on the absolute abundance of (A), S. filfiorme, (B)T. testudinum, and (C) H. wrightii, (means \pm standard error) Mean values in a group of bars followed by different letters are significantly different ( $\mathrm{p}<0.05$, Tukey's HSD test) 

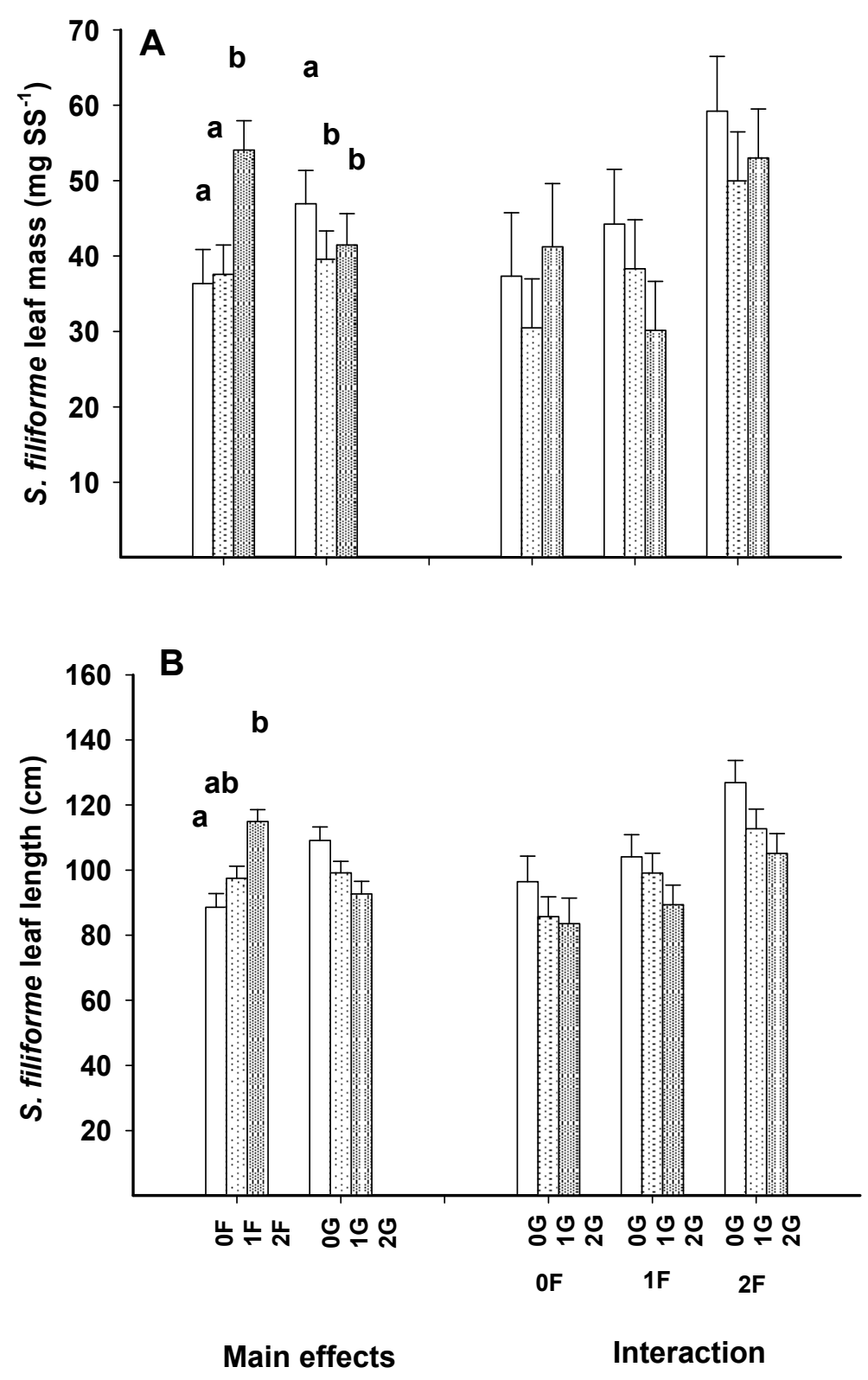

Figure 4.2. The direct and interactive effects of fertilization and grazing on $S$. filiforme (A) leaf mass, (B) leaf length(means \pm standard error). Mean values in a group of bars followed by different letters are significantly different $(\mathrm{p}<0.05$, Tukey's HSD test) 

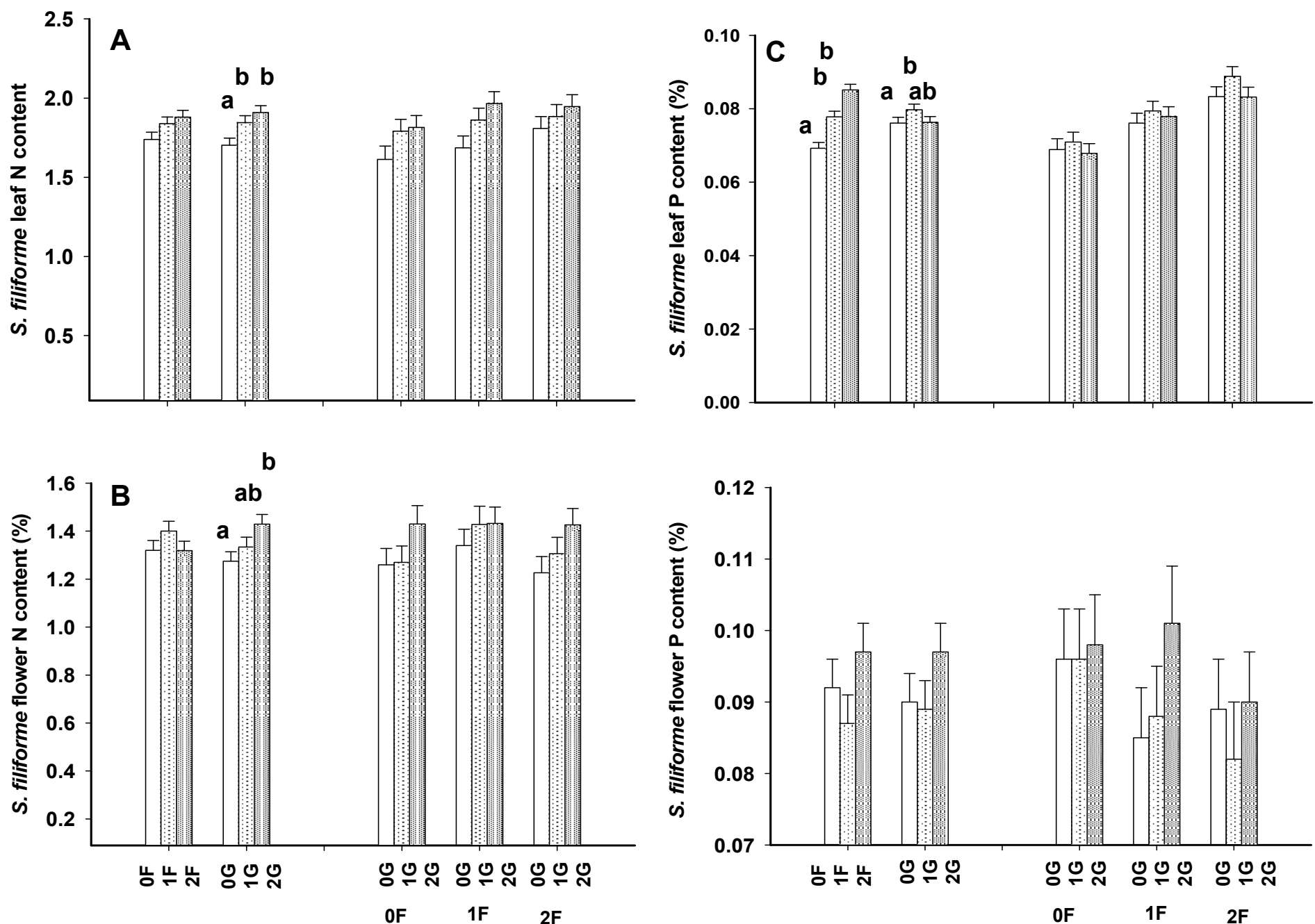

Main effects

Interaction

Main effects

Interaction

Figure 4.3. The direct and interactive effects of fertilization and simulated grazing on S. filiforme (A) leaf N content, (B) leaf P content, and (C) flower N content (means \pm standard error). Mean values in a groun of bars followed bv different letters are significantlv different ( $\mathfrak{b}<0.05$. Tukev's HSD test) 

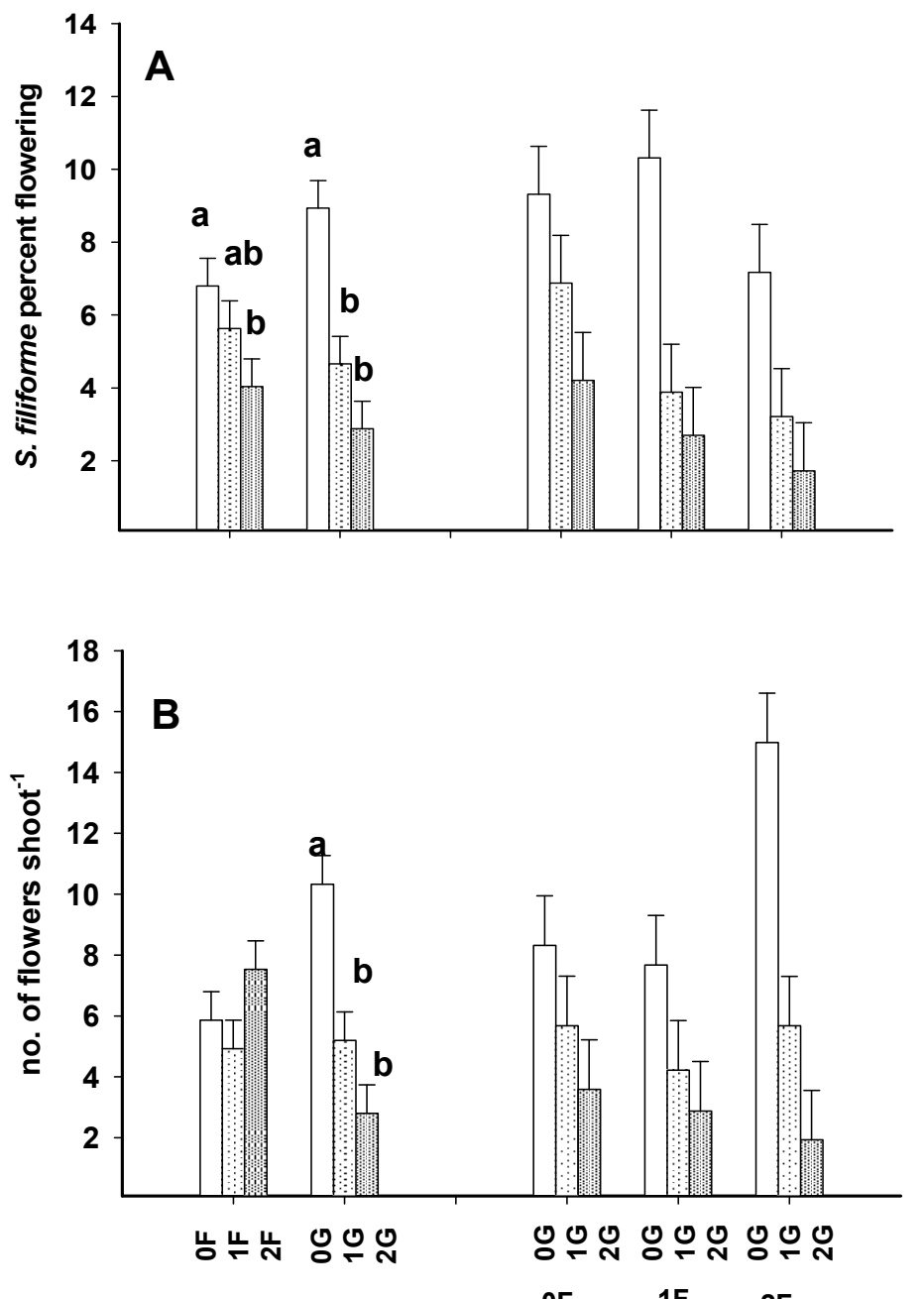

Main effects

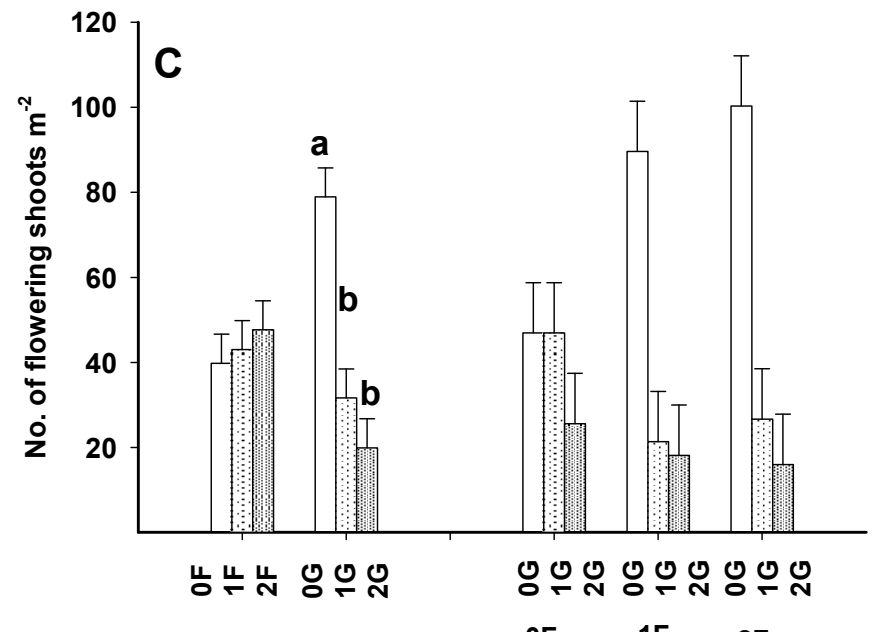

OF

Interaction

Main effects

Figure 4.4. The direct and interactive effects of fertilization and simulated grazing on $S$. filiforme (A) \% flowering, (B) number of flowers per shoot, (C) number of flowering shoots per square meter (means \pm standard error). Mean values in a group of bars

followed by different letters are significantly different $(\mathrm{p}<0.05$, Tukey's HSD test) 


\section{SYNTHESIS}

The importance of resource supply and herbivory in driving competitive interactions among species has been an important but contentious issue within ecology. These variables exhibit different effects on species competition when manipulated in isolation but interact when manipulated together. Chapters 2 and 3 discuss the results of the two-year fertilization and clipping experiment on the productivity and community structure of a subtropical seagrass bed. My study showed that fertilization and simulated grazing had strong but opposite effects on tissue nutrient content, growth rate, and species abundance in the seagrass community. There was an overall increase in plant cover and canopy height in the fertilized plots. Clipping, on the other hand decreased productivity and plant cover of the seagrasses.

My study also demonstrates that the response to nutrient addition and grazing is species specific. Species-specific responses to treatments were in part predictable as a function of plant life form and nutrient requirement. The smaller, fast growing species $H$. wrightii was favored by the combined fertilization and clipping treatment. T. testudinum which has a low nutrient requirement and extensive root and rhizome system was not negatively affected by fertilization and grazing. The slow response of $T$. testudinum to environmental stress could be due to the stored starch reserves in its extensive robust rhizome system (Zieman 1975). S. filiforme, which can branch out and form a tall canopy dominated in the fertilized plots but was not as competitive in the plots that were both grazed and enriched. The species-specific response to fertilization and grazing could have important implications on ecosystem structure and function. The interactive effects of 
fertilization and grazing on competitive interactions among species will enhance the coexistence of species possessing different plant traits and strategies that allows for efficient exploitation of all available resources and greater range of responses to disturbance or perturbation. A more diverse seagrass community will perform better when subjected to increased nutrient loading and/or grazing. Greater species diversity would enhance the resilience and recovery of the community after a disturbance. A more diverse ecosystem containing species that respond differently to multiple stressors would make the ecosystem more stable (Loreau et al. 2003, Hooper et al. 2005).

A wide variety of experiments in different ecosystems have shown that greater species diversity positively affects ecosystem functioning (reviewed in Schwartz et al., 2000, Cottingham et al., 2001, Loreau et al., 2001). Thus, maintaining greater species diversity in a seagrass bed will increase its structural complexity as a habitat and productivity. The vertical growth habit of S. filiforme and T. testudinum can form tall, multilayered canopies, which influence local hydrodynamics, promote sedimentation, and provide refuge for marine organisms (Heck 1977, Kenworthy and Schwarzschild 1998). Greater species diversity would also enhance the resilience and recovery of the community after a disturbance. A more diverse ecosystem containing species that respond differently to multiple stressors would make the ecosystem more stable (Loreau et al. 2003, Hooper et al. 2005b).

Fertilization increased competitive dominance within the primary producers while simulated grazing counteracted this effect by removal of the dominant species. Fertilization ameliorated the negative impacts of simulated grazing while simulated 
grazing prevented competitive exclusion in the fertilized plots. Nutrient addition and simulated grazing both exerted strong control on plant performance and community structure. Simulated grazing prevented competitive exclusion by the removal of the dominant species. Nutrient addition and simulated grazing both exerted strong control on plant performance. In addition, neither bottom up nor top down influences was eliminated in treatments where both factors where present. The effects of fertilization on plant performance were marked under all clipping intensities indicating that the system is regulated by $\mathrm{P}$ availability both in the presence or absence of grazers. Clipping effects were strong under both fertilized and unfertilized conditions indicating that the seagrass bed can be simultaneously under top-down control by grazers.

Most simulated grazing studies have been conducted in monospecific seagrass beds; this is the first study that evaluated the effects of simulated grazing in a mixed seagrass meadow. This study shows that if there is enough nutrient supply to support plant growth, grazing plots can sustainably support intense grazing pressure. Our results thus provide some support for theoretical expectations that anthropogenic activities that alter grazer community structure may also affect the response of marine communities to nutrient perturbations. Future studies should address the direct and interactive effects of nutrient supply and preferential grazing on community structure and relate these changes to ecosystem functions.

In Chapter 3, the results of the study suggest that nutrient addition and grazing could negatively impact flowering in seagrasses. The increase in the shoot abundance of S. filiforme in the fertilized plots, with no concomitant increase in inflorescence suggest 
that the plants invested more on vegetative growth, which is less costly than sexual reproduction and allows the plant to expand faster and be more competitive (Loehle 1987).The reduction in the shoot abundance, leaf size and flowering suggest that clipping incurred costs to both flowering and survival.

Species such as S. filiforme, with determinate inflorescence are particularly vulnerable to the effects of fertilization and grazing. A trade-off in meristem allocation between flowering and vegetative growth is particularly conspicuous in plants with determinate infloresences (Watson 1984a, Huber and During 2000). When the apical meristem of a tiller develops into a floral primordium, the tiller becomes unavailable for vegetative growth, and dies after reproduction. It could be expected that intense flowering could negatively impact vegetative growth of a plant as sexual reproduction involves a loss of existing meristems. The increase in the number of flowers per shoot in fertilized plots that were unclipped could be a mechanism to increase sexual reproduction without increasing shoot mortality due to reproduction.

The relative importance of sexual versus vegetative recruitment in a plant population could determine its survival. A decrease in sexual reproduction may strongly affect the plant's adaptation to local environments and their geographic distribution. Asexual reproduction allows populations to persist in habitats or regions where, for one reason or another, sexual reproduction cannot occur. Asexual reproduction does not involve recombination and, therefore, yields offspring that are genetically identical to each other and to the plant that produced them. The depletion of genotypic variability within clonal populations through time makes them more susceptible to diseases, 
pathogens, and environmental stochasticity (Chapin et al. 1997, Hughes and Stachowicz 2004). Future studies should investigate the impacts of increased nutrient supply and grazing intensities on the physiology of seagrass flowering to better understand the impacts of these drivers on seagrass communities. 


\section{REFERENCES}

Abal, E. G., N. Loneragan, P. Bowen, C. J. Perry, J. W. Udy, and W. C. Dennison. 1994. Physiological and morphological responses of the seagrass Zostera capricorni Aschers. to light intensity. Journal of Experimental Marine Biology \& Ecology 178:113-129.

Abrahamson, W. G. 1980. Demography and vegetative reproduction. Pages 89-106 in O. T. Solbrig, editor. Demography and evolution in plant populations. Blackwell Scientific.

Adler, P. B., D. A. Raff, and W. K. Lauenroth. 2001. The effect of grazing on the spatial heterogeneity of vegetation. Oecologia 128:465-479.

Agawin, N. S. R., C. M. Duarte, and M. D. Fortes. 1996. Nutrient limitation of Philippine seagrasses (Cape Bolinao, NW Philippines): In situ experimental evidence. Marine Ecology Progress Series 138:233-243.

Alexandre, A., R. Santos, and E. Serrao. 2005. Effects of clam harvesting on sexual reproduction of the seagrass Zostera noltii. Marine Ecology Progress Series 298:115-122.

Alonso, I. and S. E. Hartley. 1998. Effects of nutrient supply, light availability and herbivory on the growth of heather and three competing grass species. Plant Ecology 137:203-212.

Anderson, P. K. 1998. Shark bay dugongs (Dugong dugon) in summer. II: Foragers in a Halodule-dominated community. Mammalia 62:409-425.

Aragones, L. and H. Marsh. 2000. Impact of dugong grazing and turtle cropping on tropical seagrass communities. Pacific Conservation Biology 5:277-288.

Armitage, A. and J. W. Fourqurean. 2006. The short-term influence of herbivory near patch reefs varies between seagrass species Journal of Experimental Marine Biology and Ecology 339:65-74

Armitage, A., T. Frankovich, K. Heck, and J. Fourqurean. 2005. Experimental nutrient enrichment causes complex changes in seagrass, microalgae, and macroalgae community structure in Florida Bay. Estuaries and Coasts 28:422-434.

Armitage, A. R., T. A. Frankovich, and J. W. Fourqurean. 2011. Long-term effects of adding nutrients to an oligotrohic coastal environment. Ecosystems 3: 430-444.

Balestri, E. and F. Vallerini. 2003. Interannual variability in flowering of Posidonia oceanica in the North-Western Mediterranean sea, and relationships among shoot age and flowering. Botanica Marina 46: 525-530. 
Bellwood, D. R., T. P. Hughes, C. Folke, and M. Nystrom. 2004. Confronting the coral reef crisis. Nature 429:827-833.

Belsky, A. J., W. P. Carson, C. L. Jensen, and G. A. Fox. 1993. Overcompensation by plants: Herbivore optimization or red herring? Evolutionary Ecology 7:109-121.

Bjorndal, K. A. 1980. Nutrition and grazing behavior of the green turtle Chelonia mydas. Marine Biology 56:147-154.

Bloom, A. J., F. S. Chapin, III, and H. A. Mooney. 1985. Resource limitation in plantsAn economic analogy. Annual Review of Ecology and Systematics 16:363-392.

Boesch, D. F. 2002. Challenges and opportunities for science in reducing nutrient overenrichment of coastal ecosystems. Estuaries 25:886-900.

Bonsdorff, E., E. M. Blomqvist, J. Mattila, and A. Norkko. 1997. Coastal eutrophication causes, consequences and perspectives in the archipelago areas of the northern baltic sea. Estuarine Coastal and Shelf Science 44:63-72.

Borer, E. T., B. S. Halpern, and E. W. Seabloom. 2006. Asymmetry in community regulation: effects of predators and productivity. Ecology 87:2813-2820.

Borum, J. 1985. Development of epiphytic communities on eelgrass (Zostera marina) along a nutrient gradient in a Danish estuary. Marine Biology 87:211-218.

Bowen, W. D. 1997. Role of marine mammals in aquatic ecosystems. Marine Ecology Progress Series 158:267-274.

Braun-Blanquet, J. 1972. Plant sociology: the study of plant communities. Hafner Publishing Company, New York.

Bruno, J. F., J. J. Stachowitz, and M. D. Bertness. 2003. Inclusion of facilitation into ecological theory. Trends in Ecology \& Evolution 18:119-125.

Brys, R., R. P. Shefferson, and H. Jacquemyn. 2010. Impact of herbivory on flowering behaviour and life history trade-offs in a polycarpic herb: a 10-year experiment.

Oecologia.

Burd, A., B. and K. H. Dunton. 2001. Field verification of a light-driven model of biomass changes in the seagrass Halodule wrightii. Marine Ecology Progress Series 209:85-98.

Burkepile, D. E. and M. E. Hay. 2006. Herbivore vs. nutrient control of marine primary producers: context-dependent effects. Ecology 87:3128-3139. 
Campey, M. L., G. A. Kendrick, and D. I. Walker. 2002. Interannual and small-scale spatial variability in sexual reproduction of the seagrasses Posidonia coriacea and Heterozostera tasmanica, Southwestern Australia. Aquatic Botany 74:287-297.

Chapin, F. S., III, B. H. Walker, R. J. Hobbs, D. U. Hooper, J. H. Lawton, O. E. Sala, and D. Tilman. 1997. Biotic control over the functioning of ecosystems. Science 277:500504.

Chase, J. M., M. A. Leibold, A. L. Downing, and J. B. Shurin. 2000. The effects of productivity, herbivory, and plant species turnover in grassland food webs. Ecology 81:2485-2497.

Connell, J. H. 1978. Diversity in tropical rain forests and coral reefs. Science 199:13021309.

Connell, J. H. 1983. On the prevalence and relative importance of interspecific competition: evidence from field experiments. The American Naturalist 122:661-696.

Costanza, R., R. Darge, R. Degroot, S. Farber, M. Grasso, B. Hannon, K. Limburg, S. Naeem, R. V. Oneill, J. Paruelo, R. G. Raskin, P. Sutton, and M. Vandenbelt. 1997. The value of the worlds ecosystem services and natural capital. Nature 387:253-260.

Cox, P. A. 1981. Niche Partitioning between sexes of dioecious plants. The American Naturalist 117:295.

Cox, P. A., T. Elmqvist, and P. B. Tomlinson. 1990. Submarine pollination and reproductive morphology in Syringodium filiforme Cymodoceaceae. Biotropica 22:259265.

Davis, B. C. and J. W. Fourqurean. 2001. Competition between the tropical alga, Halimeda incrassata, and the seagrass, Thalassia testudinum. Aquatic Botany 71:217232.

de Mazancourt, C. and M. Loreau. 2000. Effect of herbivory and plant species replacement on primary production. American Naturalist 155:735-754.

de Mazancourt, C., M. Loreau, and L. Abbadie. 1998. Grazing optimization and nutrient cycling - when do herbivores enhance plant production. Ecology 79:2242-2252.

den Hartog, C. 1970. Sea-grasses of the world. North-Holland Publishing Company, Amsterdam. 
Deegan, L. A., A. Wright, S. G. Ayvazian, J. T. Finn, H. Golden, R. R. Merson, and J. Harrison. 2002. Nitrogen loading alters seagrass ecosystem structure and support of higher trophic levels. Aquatic Conservation: Marine \& Freshwater Ecosystems 12:193212.

Dennison, W. C. 1987. Effects of light on seagrass photosynthesis, growth and depth distribution. Aquatic Botany 27:15-26.

Diaz-Almela, E., N. Marba, and C. M. Duarte. 2007. Consequences of Mediterranean warming events in seagrass (Posidonia oceanica) flowering records. Global Change Biology 13:224-235.

Duarte, C. M. 1995. Submerged aquatic vegetation in relation to different nutrient regimes. Ophelia 41:87-112.

Duarte, C. M. and J. Cebrian. 1996. The fate of marine autotrophic production. Limnology \& Oceanography 41:1758-1766.

Duarte, C. M. and C. L. Chiscano. 1999. Seagrass biomass and production: a reassessment. Aquatic Botany 65:159-174.

Duarte, C. M., J. W. Fourqurean, D. Krause-Jensen, and B. Olesen. 2006. Dynamics of Seagrass Stability and Change, Pages 271-294 in A. W. D. Larkum, R. J. Orth, and C. M. Duarte, editors. Seagrasses: Biology, Ecology and Conservation. Sptinger, Dordrecht, The Netherlands.

Duarte, C. M. and K. Sandjensen. 1996. Nutrient constraints on establishment from seed and on vegetative expansion of the mediterranean seagrass Cymodocea nodosa. Aquatic Botany 54:279-286.

Duffy, J. E. and A. M. Harvilicz. 2001. Species-specific impacts of grazing amphipods in an eelgrass-bed community. Marine Ecology-Progress Series 223:201-211.

Durako, M. J. and M. D. Moffler. 1987. Factors affecting the reproductive ecology of Thalassia testudinum Hydrocharitaceae. Aquatic Botany 27:79-96.

Elser, J. J., M. E. S. Bracken, E. E. Cleland, D. S. Gruner, W. S. Harpole, H. Hillebrand, J. T. Ngai, E. W. Seabloom, J. B. Shurin, and J. E. Smith. 2007. Global analysis of nitrogen and phosphorus limitation of primary producers in freshwater, marine, and terrestrial ecosystems. Ecology Letters 10:1135-1142. Ecology Letters 10:1135-1142.

Engelhardt, K. A. M. and M. E. Ritchie. 2001. Effects of macrophyte species richness on wetland ecosystem functioning and services. Nature 411:687-689. 
Enriquez, S., N. Marba, J. Cebrian, and C. M. Duarte. 2004. Annual variation in leaf photosynthesis and leaf nutrient content of four Mediterranean seagrasses. Botanica Marina 47:295-306.

Enriquez, S., M. Merino, and R. Iglesias-Prieto. 2002. Variations in the photosynthetic performance along the leaves of the tropical seagrass Thalassia testudinum. Marine Biology 140:891-900.

Erftemeijer, P. L. A. and P. M. J. Herman. 1994. Seasonal changes in environmental variables, biomass, production and nutrient contents in two contrasting tropical intertidal seagrass beds in South Sulawesi, Indonesia. Oecologia 99:45-59.

Evans, J. R. 1989. Photosynthesis and nitrogen relationships in leaves of C3 plants. Oecologia 78:9-19.

Fargione, J. and D. Tilman. 2002. Competition and coexistence in terrestrial plants. Pages 165-206 in U. Sommer and B. Worm, editors. Competition And Coexistence. Springer, Berlin.

Feller, I. C. 1995. Effects of nutrient enrichment on growth and herbivory of dwarf red mangrove (Rhizophora mangle). Ecological Monographs 65:477-505.

Ferdie, M. and J. W. Fourqurean. 2004. Differential responses of benthic primary producers to nitrogen and phosphorus enrichment in a carbonate coastal marine system. Limnology and Oceanography 49:2082-2094.

Field, C. and H. A. Mooney. 1986. The photosynthesis-nitrogen relationship in wild plants.in T. J. Givnish, editor. On the economy of plant form and function : proceedings of the sixth Maria Moors Cabot Symposium, Evolutionary Constraints on Primary Productivity, Adaptive Patterns of Energy Capture in Plant. Cambridge University Press, New York.

Foster, B. L. and K. L. Gross. 1998. Species richness in a successional grassland: Effects of nitrogen enrichment and plant litter. Ecology 79:2593-2602.

Fourqurean, J. W., J. N. Boyer, M. J. Durako, L. N. Hefty, and B. J. Peterson. 2003. Forecasting responses of seagrass distributions to changing water quality using monitoring data. Ecological Applications 13:474-489.

Fourqurean, J. W., M. J. Durako, M. O. Hall, and L. N. Hefty. 2002. Seagrass distribution in south Florida: a multi-agency coordinated monitoring program. Pages 497-522 in J. W. Porter and K. G. Porter, editors. The Everglades, Florida Bay, and the coral reefs of the Florida Keys. CRC Press, Boca Raton. 
Fourqurean, J. W., G. V. N. Powell, W. J. Kenworthy, and J. C. Zieman. 1995. The effects of long-term manipulation of nutrient supply on competition between the seagrasses Thalassia testudinum and Halodule wrightii in Florida bay. Oikos 72:349-358.

Fourqurean, J. W., A. Willsie, C. D. Rose, and L. M. Rutten. 2001. Spatial and temporal pattern in seagrass community composition and productivity in south Florida. Marine Biology 138:341-354.

Fourqurean, J. W., J. C. Zieman, and G. V. N. Powell. 1992. Relationships between porewater nutrients and seagrasses in a subtropical carbonate environment. Marine Biology 114:57-65.

Freeman, D. C., L. G. Klikoff, and K. T. Harper. 1976. Differential resource utilization by the sexes of dioecious plants. Science 193:597-599.

Fridley, J. D. 2002. Resource availability dominates and alters the relationship between species diversity and ecosystem productivity in experimental plant communities. Oecologia 132:271-277.

Gallegos, M. E., M. Merino, A. Rodriguez, N. Marba, and C. Duarte. 1994. Growth patterns and demography of pioneer Caribbean seagrasses Halodule wrightii and Syringodium filiforme. Marine Ecology Progress Series 109:99-104.

Gobert, S., P. Lejeune, G. Lepoint, and J. M. Bouquegneau. 2005. C, N, P concentrations and requirements of flowering of Posidonia oceanica. Hydrobiologia 533:253-259.

Goecker, M. E., K. L. Heck, Jr., and J. F. Valentine. 2005. Effects of nitrogen content in turtlegrass, Thalassia testudinum, on consumption by the bucktooth parrotfish, Sparisoma radians. Marine Ecology Progress Series 286:239-248.

Goldberg, D. E. and T. E. Miller. 1990. Effects of different resource additions on species diversity in an annual plant community. Ecology 71:213-225.

Gough, L. and J. B. Grace. 1998. Herbivore effects on plant species density at varying productivity levels. Ecology 79:1586-1594.

Gough, L., C. W. Osenberg, K. L. Gross, and S. L. Collins. 2000. Fertilization effects on species density and primary productivity in herbaceous plant communities. Oikos 89:428439.

Grime, J. P. 1973. Competitive exclusion in herbaceous vegetation. Nature 242:344-347.

Grime, J. P. 1979. Plant Strategies and Vegetation Processes. Wiley, New York. 
Gruner, D. S. 2004. Attenuation of top-down and bottom-up forces in a complex terrestrial community. Ecology 85:3010-3022.

Gruner, D. S., J. Smith, E. , E. W. Seabloom, S. A. Sandin, J. T. Ngai, H. Hillebrand, W. S. Harpole, J. J. Elser, E. E. Cleland, M. E. S. Bracken, E. T. Borer, and B. Bolker, M. . 2008. A cross-system synthesis of consumer and nutrient resource control on producer biomass. Ecology Letters 11:740-755.

Guidetti, P. and S. Bussotti. 2002. Effects of seagrass canopy removal on fish in shallow Mediterranean seagrass (Cymodocea nodosa and Zostera noltii) meadows: a local-scale approach. Marine Biology 140:445-453.

Gulmon, S. L. and C. C. Chu. 1981. The effects of light and nitrogen on photosynthesis, leaf characteristics, and dry matter allocation in the chaparral shrub, Diplacus aurantiacus. Oecologia 49:207-212.

Hartley, S. E. and R. J. Mitchell. 2005. Manipulation of nutrients and grazing levels on heather moorland: changes in Calluna dominance and consequences for community composition. Journal of Ecology 93:990-1004.

Hautier, Y., P. A. Niklaus, and A. Hector1. 2009. Competition for light causes plant biodiversity loss after eutrophication. Science 324:636 - 638 .

Hawkes, C. V. and J. J. Sullivan. 2001. The impact of herbivory on plants in different resource conditions: A meta-analysis. Ecology 82:2045-2058.

Hay, M. E. 1984. Patterns of fish and urchin grazing on Caribbean coral reefs: Are previous results Typical? Ecology 65:446-454.

Heck, K. L., K. W. Able, C. T. Roman, and M. P. Fahay. 1995. Composition, abundance, biomass, and production of macrofauna in a new england estuary - comparisons among eelgrass meadows and other nursery habitats. Estuaries 18:379-389.

Heck, K. L. J. 1977. Comparative Species Richness Composition and Abundance of Invertebrates in Caribbean Seagrass Thalassia testudinum Meadows Panama. Marine Biology 41:335-348.

Hemminga, M. A. and C. M. Duarte. 2000. Seagrass ecology. Cambridge University Press, Cambridge.

Herbert, D. A. and J. W. Fourqurean. 2008. Ecosystem structure and function still altered two decades after short-term fertilization of a seagrass meadow. Ecosystems 11:688-700. 
Hickman, K. R. and D. C. Hartnett. 2002. Effects of grazing intensity on growth, reproduction, and abundance of three palatable forbs in Kansas tallgrass prairie. Plant Ecology 159:23-33.

Hilbert, D. W., D. M. Swift, J. K. Detling, and M. I. Dyer. 1981. Relative growth rates and the grazing optimization hypothesis. Oecologia 51:14-18.

Hillebrand, H. 2003. Opposing effects of grazing and nutrients on diversity. Oikos 100:592-600.

Hillebrand, H., D. S. Gruner, E. T. Borer, M. E. S. Bracken, E. E. Cleland, J. J. Elser, W. S. Harpole, J. T. Ngai, E. W. Seabloom, J. B. Shurin, and J. E. Smith. 2007. Consumer versus resource control of producer diversity depends on ecosystem type and producer community structure. Proceedings of the National Academy of Sciences 104:1090410909.

Hillebrand, H., B. Worm, and H. K. Lotze. 2000. Marine microbenthic community structure regulated by nitrogen loading and grazing pressure. Marine Ecology Progress Series 204:27-38.

Holderegger, R., I. Stehlik, and J. Schneller, Jakob. 1998. Estimation of the relative importance of sexual and vegetative reproduction in the clonal woodland herb Anemone nemorosa. Oecologia 117:105-107.

Hooper, D. U., F. S. Chapin, J. J. Ewel, A. Hector, P. Inchausti, S. Lavorel, J. H. Lawton, D. M. Lodge, M. Loreau, S. Naeem, B. Schmid, H. Setala, A. J. Symstad, J. Vandermeer, and D. A. Wardle. 2005a. Effects of biodiversity on ecosystem functioning: A consensus of current knowledge. Ecological Monographs 75:3-35.

Huber, H. and H. During. 2000. No long-term costs of meristem allocation to flowering in stoloniferous Trifolium species. Evolutionary Ecology 14:731-748.

Hughes, A. R. and J. J. Stachowicz. 2004. Genetic diversity enhances the resistance of a seagrass ecosystem to disturbance. Proceedings of the National Academy of Sciences of the United States of America 101:8998-9002.

Hughes, T. P., A. H. Baird, D. R. Bellwood, M. Card, S. R. Connolly, C. Folke, R. Grosberg, O. Hoegh-Guldberg, J. B. C. Jackson, J. Kleypas, J. M. Lough, P. Marshall, M. Nystrom, S. R. Palumbi, J. M. Pandolfi, B. Rosen, and J. Roughgarden. 2003. Climate change, human impacts, and the resilience of coral reefs. Science 301:929-933.

Huston, M. 1979. A general hypothesis of species diversity. American Naturalist 113:81101.

Huston, M. A. 1994. Biological Diversity. The coexistence of species on changing landscapes. Cambridge University Press, Cambridge, UK. 
Jackson, J. B. C. 2001. What was natural in the coastal oceans? Proceedings of the National Academy of Sciences of the United States of America 98:5411-5418.

Jackson, J. B. C., M. X. Kirby, W. H. Berger, K. A. Bjorndahl, L. W. Botsford, B. J. Bourque, R. H. Bradbury, R. Cooke, J. Erlandson, J. A. Estes, T. P. Hughes, S. Kidwell, C. B. Lange, H. S. Lenihan, J. M. Pandolfi, C. H. Peterson, R. S. Steneck, M. J. Tegner, and R. R. Warner. 2001. Historical overfishing and the recent collapse of coastal ecosystems. Science 293:629-638.

Johnson, E. A. and S. L. Williams. 1982. Sexual reproduction in seagrasses: reports for five Caribbean species with details for Halodule wrightii Aschers. and Syringodium filiforme Kutz. Caribbean Journal of Science 18:61-70.

Kenworthy, W. J. and A. C. Schwarzschild. 1998. Vertical growth and short-shoot demography of Syringodium filiforme in outer Florida Bay, USA. Marine Ecology Progress Series 173:25-37.

Kerr, E. A. and S. Strother. 1989. Seasonal changes in leaf growth rate of ZosteraMuelleri Irmisch Ex Aschers. in South-Eastern Australia. Aquatic Botany 33:131-140.

Kirchner, T. B. 1977. The effects of resource enrichment on the diversity of plants and arthropods in a shortgrass prairie. Ecology 58:1334-1344.

Kirsch, K. D., J. F. Valentine, and K. L. Heck. 2002. Parrotfish grazing on turtlegrass Thalassia testudinum: evidence for the importance of seagrass consumption in food web dynamics of the Florida Keys National Marine Sanctuary. Marine Ecology Progress Series 227:71-85.

Koch, E. W. 1999. Sediment resuspension in a shallow Thalassia testudinum banks ex Konig bed. Aquatic Botany 65:269-280.

Kondoh, M. 2001. Unifying the relationships of species richness to productivity and disturbance. Proceedings of the Royal Society of London - Series B: Biological Sciences 268:269-271.

Lang, Anton. 1952 Physiology of flowering. Annual Review of Plant Physiology. 3: 265306

Les, D. H., M. A. Cleland, and M. Waycott. 1997. Phylogenetic studies in Alismatidae, ii - evolution of marine angiosperms (seagrasses) and hydrophily. Systematic Botany

22:443-463. 
Littler, M. M., D. S. Littler, and B. E. Lapointe. 1988. A comparison of nutrient- and light-limited photosynthesis in psammophytic versus epilithic forms of Halimeda (Caulerpales, Halimedaceae) from the Bahamas. Coral Reefs 6:219-225.

Loehle, C. 1987. Partitioning of reproductive effort in clonal plants: A benefit-cost model. Oikos 49:199-208.

Loreau, M. and N. Behera. 1999. Phenotypic diversity and stability of ecosystem processes. Theoretical Population Biology 56:29-47.

Loreau, M., N. Mouquet, and A. Gonzalez. 2003. Biodiversity as spatial insurance in heterogeneous landscapes. Proceedings of the National Academy of Sciences of the United States of America 100:12765-12770.

Lovett Doust, J. 1989. Plant reproductive strategies and resource allocation. Trends in Ecology and Evolution 4:230-234.

Lovett Doust, J. and G. Laporte. 1991. Population sex ratios, population mixtures and fecundity in a clonal dioecious macrophyte, Vallisneria americana. Journal of Ecology 79: 477-489.

Lubchenco, J. 1978. Plant species diversity in a marine intertidal community: importance of herbivore food preference and algal competitive abilities. American Naturalist 112:2339.

Marba, N., E. Gallegos Margarita, M. Merino, and M. Duarte Carlos. 1994. Vertical growth of Thalassia testudinum: Seasonal and interannual variability. Aquatic Botany 47:1-11.

Marba, N., M. A. Hemminga, M. A. Mateo, C. M. Duarte, Y. E. M. Mass, J. Terrados, and E. Gacia. 2002. Carbon and nitrogen translocation between seagrass ramets. Marine Ecology Progress Series 226:287-300.

Marbà, N. and D. I. Walker. 1999. Growth, flowering and population dynamics of temperate Western Australian seagrasses. Marine Ecology Progress Series 184:105-118.

Maschinski, J. and T. G. Whitham. 1989. The continuum of plant responses to herbivory: The influence of plant association, nutrient availability, and timing. The American Naturalist 134: 1-19

McGlathery, K. J. 1995. Nutrient and grazing influences on a subtropical seagrass community. Marine Ecology Progress Series 122:239-252.

McMillan, C. 1976. Experimental studies on flowering and reproduction in seagrasses. Aquatic Botany 2:87-92. 
McMillan, C. 1980a. Flowering under controlled conditions by Cymodocea serrulata, Halophila stipulacea, Syringodium isoetifolium, Zostera capensis and Thalassia hemprichii from Kenya. Aquatic Botany 8:323-336.

McMillan, C. 1980b. Reproductive physiology in the seagrass, Syringodium filiforme, from the Gulf of Mexico and the Caribbean. American Journal of Botany 67:104-110.

McMillan, C. 1981. Seed reserves and seed germination for two seagrasses, Halodule wrightii and Syringodium filiforme, form the Western Atlantic. Aquatic Botany 11:279296.

McNaughton, S. J. 1979. Grazing as an optimization process: grass-ungulate relationships in the Serengeti. The American Naturalist 113:691.

McNaughton, S. J. 1985. Ecology of a grazing ecosystem: the Serengeti. Ecological Monographs 55:259-294.

Moncreiff, C. A. and M. J. Sullivan. 2001. Trophic importance of epiphytic algae in subtropical seagrass beds: evidence from multiple stable isotope analyses. Marine Ecology Progress Series 215:93-106.

Mooney, H. A., J. Lubchenco, R., Dirzo, and O. E. Sala. 1995. Biodiversity and Ecosystem Functioning: Basic Principles. In: Global Biodiversity Assessment. Cambridge University Press., New York.

Moran, K. L. and K. A. Bjorndal. 2005. Simulated green turtle grazing affects structure and productivity of seagrass pastures. Marine Ecology Progress Series 305: 235-247

Moran, K. L. and K. A. Bjorndal. 2007. Simulated green turtle grazing affects nutrient composition of the seagrass Thalassia testudinum. Marine Biology 150:1083-1092

Mortimer, J. A. 1981. The feeding ecology of the West Caribbean green turtle (Chelonia mydas) in Nicaragua. Biotropica 13:49-58.

Olsen, Y. and I. Valiela. 2010. Effect of sediment nutrient enrichment and grazing on turtle grass Thalassia testudinum in Jobos Bay, Puerto Rico. Estuaries and Coasts 33:769783.

Orth, R. J., T. J. B. W. C. D. Carruthers, C. M. Duarte, J. Fourqurean, K. L. Heck, A. R. Hughes, G. A. Kendrick, J. W. Kenworthy, S. Olyarnik, F. T. Short, M. Waycott, and S. Williams. 2006. A global crisis for seagrass ecosystems. BioScience 56:987-996. 
Penhale, P. A. 1977. Macrophyte-epiphyte biomass and productivity in an eelgrass (Zostera marina L.) community. Journal of Experimental Marine Biology and Ecology 26:211-224.

Piazzi, L., E. Balestri, and F. Cinelli. 2000. Grazing of inflorescences of the seagrass Posidonia oceanica (L.) Delile. Botanica Marina 43:581-584.

Proulx, M. and A. Mazumder. 1998. Reversal of grazing impact on plant species richness in nutrient-poor vs nutrient-rich ecosystems. Ecology 79:2581-2592.

Rajaniemi, T. K. 2002. Why does fertilization reduce plant species diversity? Testing three competition-based hypotheses. Journal of Ecology 90:316-324.

Reader, R. J. and B. J. Best. 1989. Variation in competition along an environmental gradient: Hieracium floribundum in an abandoned pasture. Journal of Ecology 77:673684.

Ritchie, M. E. and D. Tilman. 1995. Responses of legumes to herbivores and nutrients during succession on a nitrogen-poor soil. Ecology 76:2648-2655.

Rooney, T. P. 1997. Escaping herbivory: refuge effects on the morphology and shoot demography of the clonal forest herb Maianthemum canadense. Journal of the Torrey Botanical Society 124:280-285.

Rose, C. D., W. C. Sharp, W. J. Kenworthy, J. H. Hunt, W. G. Lyons, E. J. Prager, J. F. Valentine, M. O. Hall, P. E. Whitfield, and J. W. Fourqurean. 1999. Overgrazing of a large seagrass bed by the sea urchin Lytechinus variegatus in Outer Florida Bay. Marine Ecology Progress Series 190:211-222.

Schwarzschild, A. C., J. W. Kenworthy, and J. C. Zieman. 2008. Leaf Growth of the seagrass Syringodium filiforme in outer Florida Bay, Florida. Bulletin of Marine Science 83:571-585.

Schwinning, S. and J. Weiner. 1998. Mechanisms determining the degree of size asymmetry in competition among plants. Oecologia 113:447-455.

Short, F. T., J. Montgomery, C. F. Zimmermann, and C. A. Short. 1993. Production and nutrient dynamics of a Syringodium filiforme Kutz. seagrass bed in Indian River Lagoon, Florida. Estuaries 16:323-334.

Short, F. T. and S. Wyllie-Echeverria. 1996. Natural and human-induced disturbance of seagrasses. Environmental Conservation 23:17-27.

Silliman, B. R. and J. C. Zieman. 2001. Top-down control of Spartina alterniflora production by periwinkle grazing in a Virginia salt marsh. Ecology 82:2830-2845. 
Silvertown, J. 2008. The evolutionary maintenance of sexual reprodcution: evidence from the ecological distribution of asexual reproduction in clonal plants. International Journal of Plant Science. 169:157-168.

Terrados, J., C. M. Duarte, and W. J. Kenworthy. 1997. Is the apical growth of Cymodocea nodosa dependent on clonal integration. Marine Ecology Progress Series 158:103-110.

Thayer, G. W., K. A. Bjorndal, J. C. Ogden, S. L. Williams, and J. C. Zieman. 1984. Role of larger herbivores in seagrass communities. Estuaries 7:351-376.

Tilman, D. 1982. Resource Competition and Community Structure. Princeton University Press.

Tilman, D. 1988. Plant strategies and the dynamics and function of plant communities. Princeton University Press, Princeton, N. J.

Tilman, D. 1990. Mechanisms of plant competition for nutrients: the elements of a predictive theory of competition. Page 484p in J. B. Grace and D. Tilman, editors. Perspectives on Plant Competition. The Blackburn Press, New Jersey.

Tomlinson, P. B. 1974. Vegetative morphology and meristem dependence - the foundation of productivity in seagrasses. Aquaculture 4:107-130.

Udy, J. W., W. C. Dennison, W. J. Lee Long, and L. J. McKenzie. 1999. Responses of seagrasses to nutrients in the Great Barrier Reef, Australia. Marine Ecology Progress Series 185:257-271.

Valentine, J. F. and K. L. Heck. 1999. Seagrass herbivory: evidence for the continued grazing of marine grasses. Marine Ecology Progress Series 176:291-302.

Vallejo-Marin, M., M. E. Dorken, and S. C. H. Barrett. 2010. The ecological and evolutionary consequences of clonality for plant mating. Annual Review of Ecology, Evolution, and Systematics 41:193-213.

van Keulen, M. and A. Borowitzka Michael. 2002. Comparison of water velocity profiles through morphologically dissimilar seagrasses measured with a simple and inexpensive current meter. Bulletin of Marine Science 71:1257-1267.

van Tussenbroek, B. I., J. A. Vonk, J. Stapel, P. L. A. Erftemeijer, J. J. Middelburg, and J. C. Zieman. 2006. The biology of Thalassia: paradigms and recent advances. Pages 409-439 in A. W. D. Larkum, R. J. Orth, and C. M. Duarte, editors. Seagrasses: Biology, ecology and conservation. Springer, Dordrecht, The Netherlands. 
Vergés, A., M. Pérez, T. Alcoverro, and J. Romero. 2008. Compensation and resistance to herbivory in seagrasses: induced responses to simulated consumption by fish.

Oecologia 155:751-760.

Vilà, M. and J. Terradas. 1995. Effects of nutrient availability and neighbours on shoot growth, resprouting and flowering of Erica multiflora. Journal of Vegetation Science 6:411-416.

Walters, M. B. and P. B. Reich. 1999. Research Review: Low-light carbon balance and shade tolerance in the seedlings of woody plants: Do winter deciduous and broad-leaved evergreen species differ? New Phytologist 143:143-154.

Watson, M. A. 1984. Developmental constraints: effect on population growth and patterns of resource allocation in a clonal plant. The American Naturalist 123:411-426.

Williams, S. L. 1987. Competition between the seagrasses Thalassia testudinum and Syringodium filiforme in a Caribbean lagoon. Marine Ecology Progress Series 35:91-98.

Williams, S. L. 1988. Thalassia testudinum productivity and grazing by green turtles in a highly disturbed seagrass bed. Marine Biology 98:447-455.

Wilson, S. D. and D. Tilman. 1991. Interactive effects of fertilization and disturbance on community structure and resource availability in an old-field plant community.

Oecologia, Berlin 88:61-71.

Wittmann, K. J. and J. A. Ott. 1982. Effects of cropping on growth of the Mediterranean seagrass Posidonia oceanica. Marine Ecology 3:151-160.

Wootton, J. T. 1998. Effects of disturbance on species diversity - a multitrophic perspective. American Naturalist 152:803-825.

Worm, B., H. K. Lotze, C. Bostrom, R. Engkvist, V. Labanauskas, and U. Sommer. 1999. Marine diversity shift linked to interactions among grazers, nutrients and propagule banks. Marine Ecology Progress Series 185:309-314.

Worm, B., H. K. Lotze, H. Hillebrand, and U. Sommer. 2002. Consumer versus resource control of species diversity and ecosystem functioning. Nature 417:848-851.

Worm, B., H. K. Lotze, and U. Sommer. 2000. Coastal food web structure, carbon storage, and nitrogen retention regulated by consumer pressure and nutrient loading. Limnology \& Oceanography 45:339-349.

Yanovsky, M. J. and S. A. Kay. 2003. Living by the calendar: how plants know when to flower. Nature Reviews Molecular Cell Biology 4:265(212). 
Zieman, J. C. 1974. Methods for the study of the growth and production of turtle grass, Thalassia testudinum König. Aquaculture 4:139-143.

Zieman, J. C. 1975. Seasonal variation of turtle grass, Thalassia testudinum König, with reference to temperature and salinity effects. Aquatic Botany 1:107-123.

Zieman, J. C., J. W. Fourqurean, and R. L. Iverson. 1989. Distribution, abundance and productivity of seagrasses and macroalgae in Florida Bay. Bulletin of Marine Science 44:292-311 


\section{VITA}

\section{SITTI ZAYDA HALUN}

Born Bongao, Tawi-Tawi, Philippines

1983-1987

B.S. Biology, Silliman University, Philippines

1998-2002

M.Sc. in Environmental Science, University of the Philippines, Philippines

2003-2006

Fulbright fellow

2003-2006

Teaching Assistant for Human Biology,

2010-2011 Plant Ecology, Introduction to Botany, Great Ideas in Science Labs, Florida International University, Miami, FL

2006-2009

Research Assistant, Florida Keys Marine Sanctuary Monitoring Project and Florida Coastal Everglades Long Term Ecological Research

2005-2011

Doctoral Candidate, Biology, Florida International University, Miami, FL

\section{Research Experiences}

Demographic dynamics of tropical seagrass beds in Ulugan Bay, Palawan, Philippines, UNESCO chair in integrated and sustainable development in coastal regions and islands (1999)

PREDICT project (Prediction of the resilience and recovery of disturbed coastal communities in the tropics), a collaboration among seven countries (Spain, Portugal, United Kingdom, The Netherlands, Denmark, Vietnam and the Philippines. Conducted field surveys and experimental work to develop models to predict the resilience and recovery of the habitat, plant communities, and food webs supported by the plant communities in the tropics (1999-2001)

Long term monitoring of seagrass ecosystems in the Florida Keys National Marine Sanctuary and Florida Coastal Everglades LTER sites. Participated in collecting data on water quality and benthic communties (2003-present). 
Publications:

Halun, Z, Terrados, J, Borum, J, Kamp-Nielsen, L, Duarte, CM and Fortes, MD. 2002. Experimental evaluation of the effects of siltation-derived changes in sediment conditions on the Philippine seagrass Cymodocea rotundata Journal of Experimental Marine Biology and Ecology. 279:73-87.

Marba, Nuria, Duarte Carlos, Terrados, Jorge, Halun, Zayda, Gacia, espernca, Fortes, Miguel D. 2010.Effects of seagrass rhizospheres on sediment redox conditions in SE Asian coastal ecosystems. Estuaries and Coasts. 33: 107-117

Presentations:

Halun, S.Z., Fourqurean J. W. 2010. Effects of fertilization and simulated grazing on the community structure of a seagrass bed in South Florida. Benthic Ecology Meeting, Wilmington, North Carolina

Halun S.Z., Fourqurean J. W. 2009. Effects of fertility and herbivory on the community structure of a subtropical seagrass bed. Florida Bay Meeting, Naples, Florida

Halun S.Z., Fourqurean J. W. 2008. Species Species Richness Of Marine Benthic Habitats in South Florida. International Coral Reef Symposium, Fort Lauderdale, Florida

Halun, S.Z., Terrados J., Kamp-Nielsen, L., Borum, J., Fortes, M.D. 2002. The effects of sulfide on the performance of the tropical seagrass Cymodocea rotundata. $5^{\text {th }}$ International Seagrass Biology Workshop. Ensenada, Baja California, México

Halun S.Z., Borum J, Pedersen O, Terrados, J., Fortes MD. 2000. Variation in root porosity of Cymodocea rotundata in Cape Bolinao, Pangasinan (NW Philippines): relationship with sediment conditions. Fourth International Seagrass Biology Workshop. Corsica, France

Special Skills:

AAUS certified scientific diver since 2006

NAUI certified rescue diver since 2006

NAUI Open Water and Nitrox Certified Diver

- Certified Small Boat Driver, Motorboat Operators Certification Course, Florida 